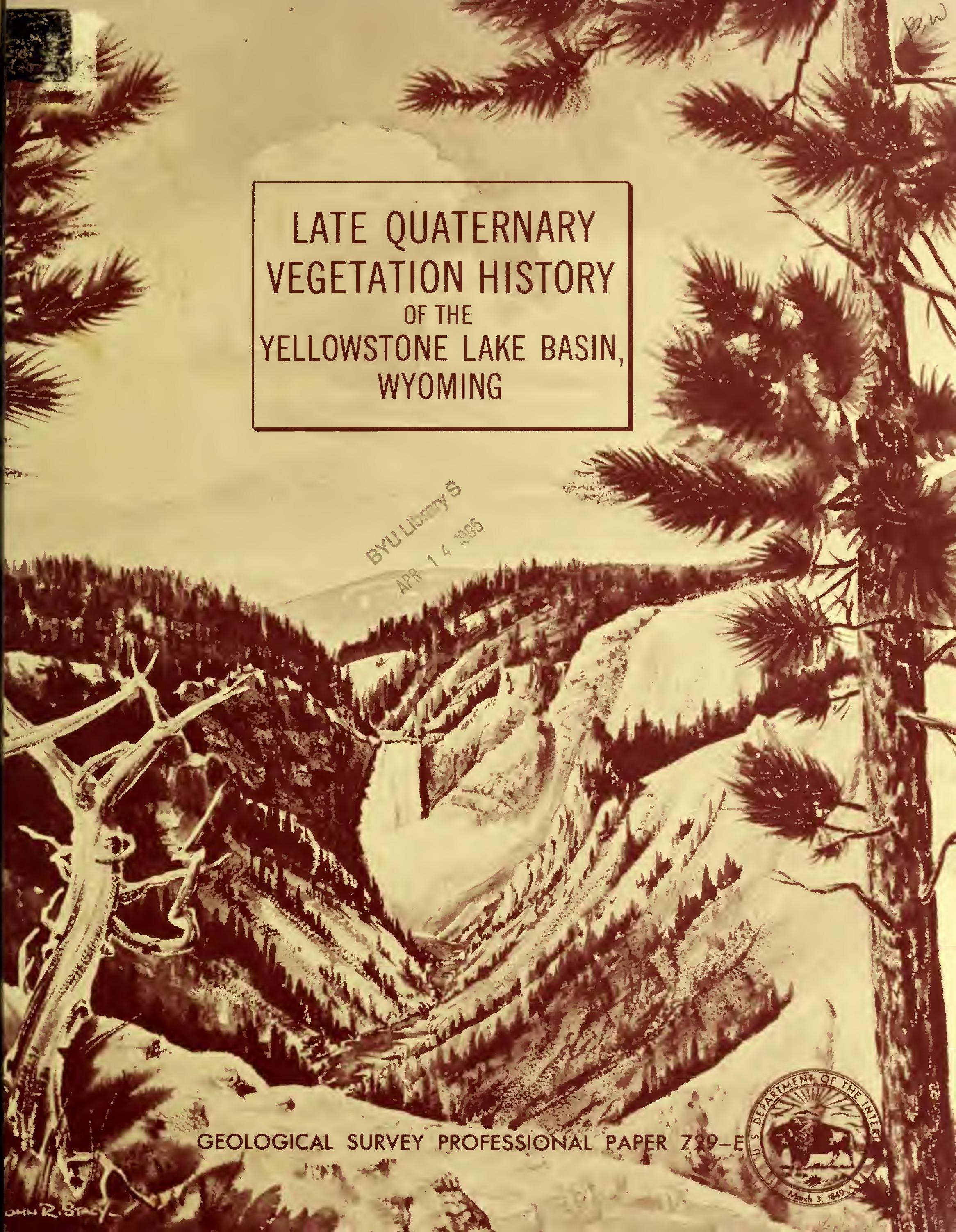




$$
4
$$




\section{Late Quaternary}

\section{Vegetation History of the}

Yellowstone Lake Basin,

\section{Wyoming}

$B y$ RICHARD G. BAKER

\section{GEOLOGY OF YELLOWSTONE NATIONAL PARK}

GEOLOGICAL SURVEY PROFESSIONAL PAPER 729-E

Analyses of pollen and plant macrofossils from sediment cores indicate complex changes in the vegetation succession from deglaciation about 13,000 years ago to the present

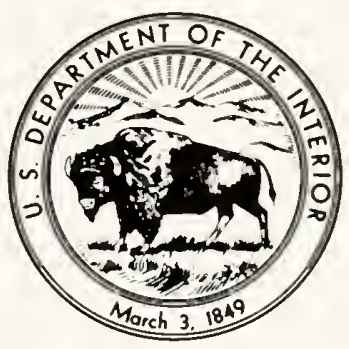




\section{UNITED STATES DEPARTMENT OF THE INTERIOR}

THOMAS S. KLEPPE, Secretary

\section{GEOLOGICAL SURVEY}

V. E. McKelvey, Director

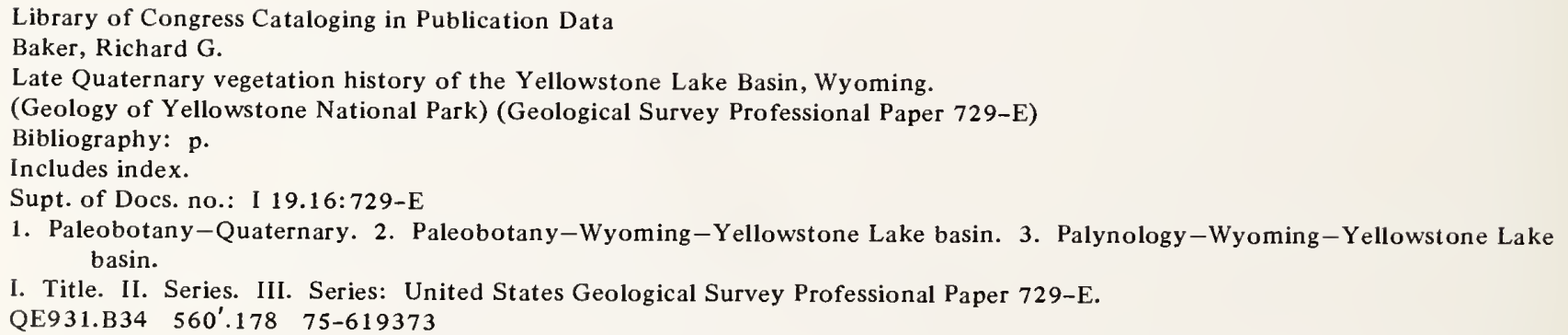

1. Paleobotany-Quaternary. 2. Paleobotany-Wyoming-Yellowstone Lake basin. 3. Palynology-Wyoming-Yellowstone Lake basin.

I. Title. II. Series. III. Series: United States Geological Survey Professional Paper 729-E.

QE931.B34 560'.178 75-619373

For sale by the Superintendent of Documents, U.S. Government Printing Office Washington, D.C. 20402

Stock Number 024-001-02860-3 


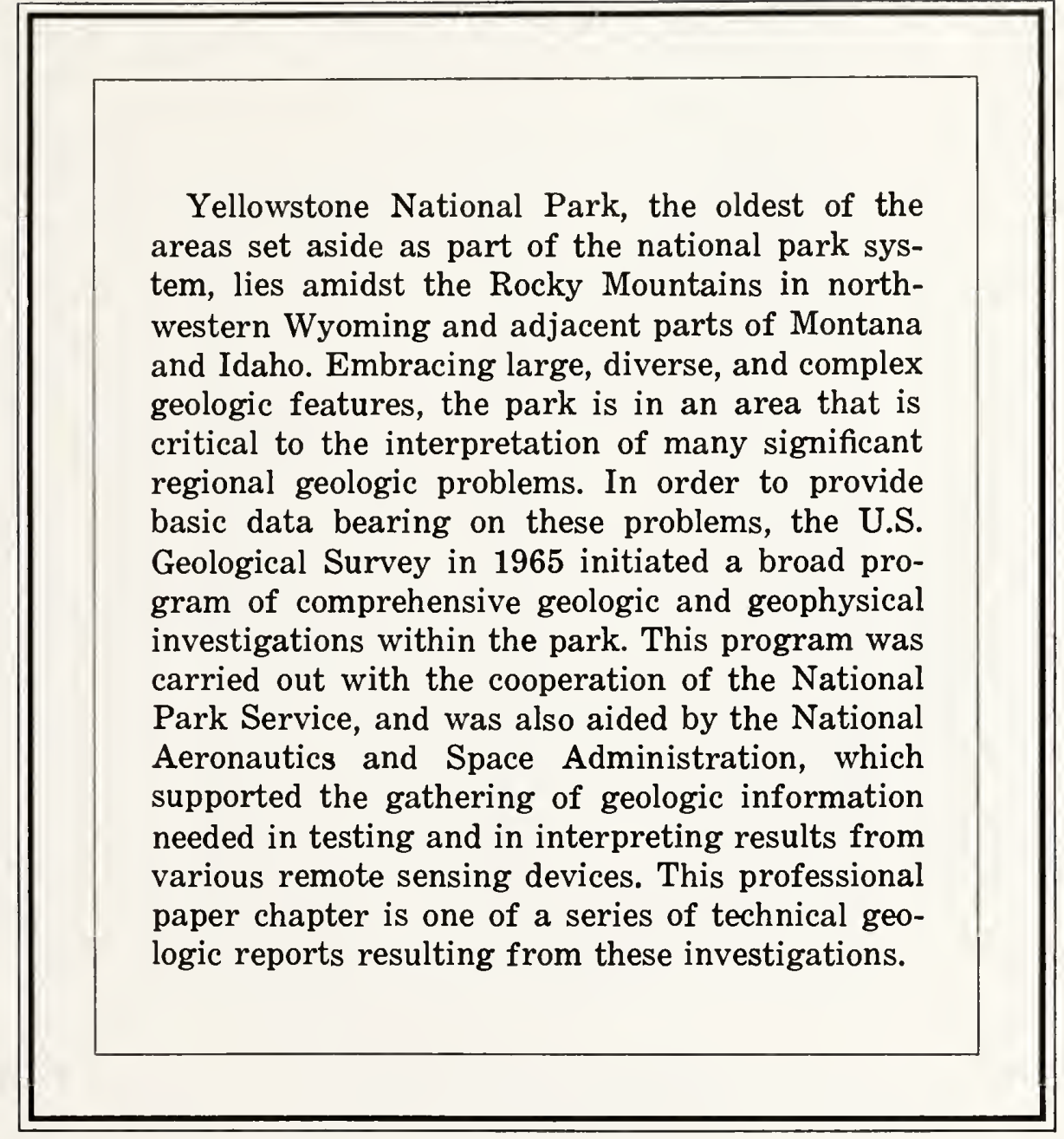




\section{Digitized by the Internet Archive in 2013}

http://archive.org/details/latequaternaryve00bake 


\section{CONTENTS}

Metric-English equivalents $\ldots \ldots \ldots \ldots \ldots \ldots \ldots \ldots$ VI

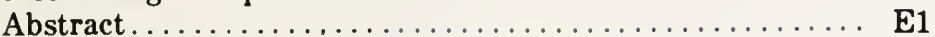

Introduction ............................. 1

Location and climate.................... 1

Acknowledgments ...................... 2

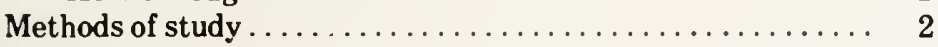

Glacial history ........................... 5

Vegetation of Yellowstone National Park and surrounding area 7

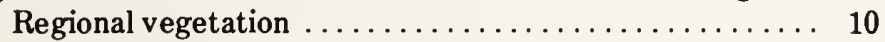

Artemisia steppe association.............. 10

Pseudotsuga association ................ 10

Pinus contorta forest association ............ 12

Picea-Abies-Pinus albicaulis forest association ..... 12

Alpine association .................. 12

Local vegetation around the coring sites . . . . . . . . 13

Nuphar-Potamogeton type ............... 14

Menyanthes trifoliata type ............... 14

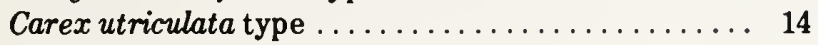

Carex diandra-Potentilla palustris type ......... 14

Calamagrostis-Salix-Sedum rhodanthum type...... 15

Other paleobotanical work in the area ........... 15

Pollen surface samples . . . . . . . . . . . . . . . . . 15

Surface samples from the Artemisia steppe ......... 16

Surface sample from Pseudotsuga association ......... 18

Surface samples in Pinus contorta forests........... 18

Surface samples from Picea-Abies-Pinus albicaulis

forests........................ 18

Surface samples from Picea-Abies-Pinus albicaulis

parklands and tundra .................. 19

Pollen ratios . . . . . . . . . . . . . . . . . . 20

Quaternary palynology $\ldots \ldots \ldots \ldots \ldots \ldots \ldots \ldots \ldots \ldots \ldots, 20$

Materials and procedures $\ldots \ldots \ldots \ldots \ldots \ldots \ldots \ldots 20$

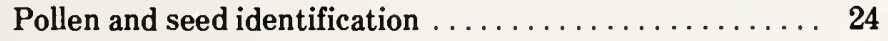

Selaginellaceae ..................... 24

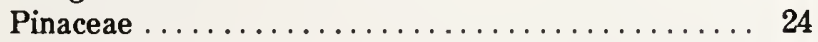

Betulaceae ..................... 27
Quatenary palynology-Continued Page

Pollen and seed identification-Continued

Compositae....................... E28

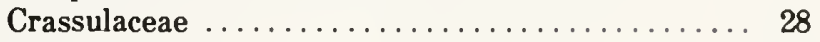

Cruciferae............................. 28

Haloragaceae ...................... 28

Loranthaceae ..................... 28

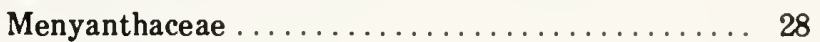

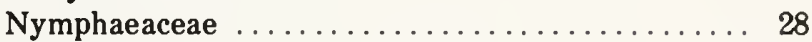

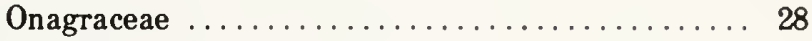

Polemoniaceae ...................... 28

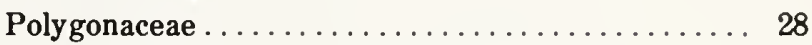

Ranunculaceae..................... 29

Rosaceae ... . . . . . . . . . . . . . . . . . . . . 29

Salicaceae ........................ 29

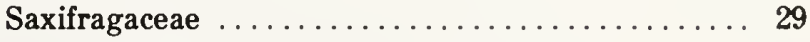

Cyperaceae........................... 29

Gramineae ....................... 30

Naiadaceae ... . . . . . . . . . . . . . . . . . . . . 30

Typhaceae ........................... 30

Other types of fossils ................ 30

Algae............................ 30

Description of pollen zones $\ldots \ldots \ldots \ldots \ldots \ldots \ldots \ldots$

Picea-Juniperus-Pinus albicaulis zone $(960-770 \mathrm{~cm}) \ldots \ldots \ldots \ldots \ldots \ldots \ldots \ldots . . . \ldots 30$

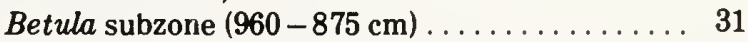

Populus subzone $(875-770 \mathrm{~cm}) \ldots \ldots \ldots \ldots \ldots . \ldots \ldots$

Pinus contorta zone $(770-0 \mathrm{~cm}) \ldots \ldots \ldots \ldots \ldots . \ldots 36$

Pinus contorta-Pinus albicaulis subzone $(770-600 \mathrm{~cm}) \ldots \ldots \ldots \ldots \ldots \ldots \ldots . \ldots . \ldots 37$

Pinus contorta subzone $(600-420 \mathrm{~cm}) \ldots \ldots \ldots 37$

Picea-Abies-Pinus conturta subzone $(420-0 \mathrm{~cm}) \ldots \ldots \ldots \ldots \ldots \ldots \ldots \ldots \ldots \ldots . \ldots \ldots$

Discussion and conclusions $\ldots \ldots \ldots \ldots \ldots \ldots \ldots \ldots \ldots$

References cited $\ldots \ldots \ldots \ldots \ldots \ldots \ldots \ldots \ldots \ldots \ldots \ldots \ldots \ldots, 41$

Index $\ldots \ldots \ldots \ldots \ldots \ldots \ldots \ldots \ldots \ldots \ldots \ldots \ldots \ldots, \ldots \ldots \ldots$

\section{ILLUSTRATIONS}

[Plates follow index]

Plate 1 - 4. Photomicrographs of fossil pollen grains from Buckbean fen.

5 - 10. Photomicrographs of plant macrofossils and modern seeds and fruits.

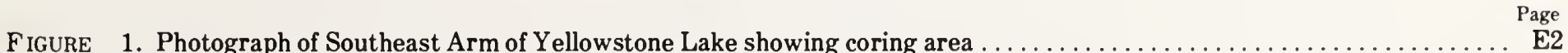

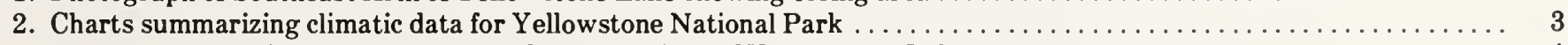

3. Photograph showing shorelines above Southeast Arm of Yellowstone Lake . . . . . . . . . . . . . . . . . . 4

4. Schematic cross section showing relationship between Two Ocean Plateau, the filled lagoons, the lake levels, and the

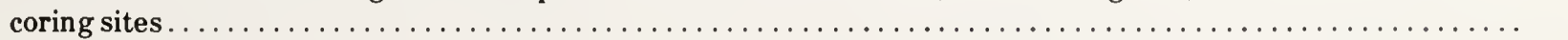

5. Sketch maps showing geomorphic development of coring area as glacier ice melted and lake level fell . . . . . . . . 6

6. Vegetation map of the southeast corner of Yellowstone National Park showing highest lake level ..............11 
Figure 7. Map of local vegetation around coring site, showing surface sample and core localities at Buckbean fen and Lilypad

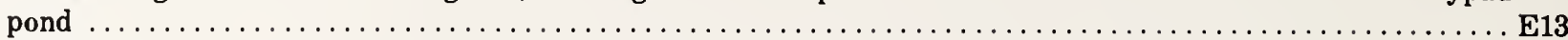

8- 11. Photographs:

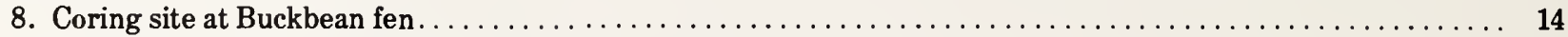

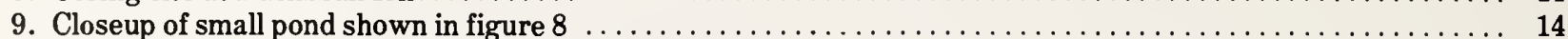

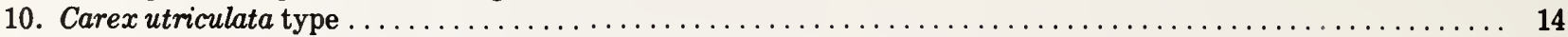

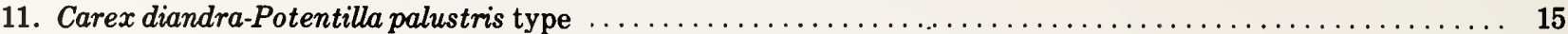

12. Map of Yellowstone National Park, showing localities of surface samples and coring areas. . . . . . . . . . . . . 16

13. Diagram showing pollen from surface samples arranged by elevations and by vegetation types $\ldots \ldots \ldots \ldots \ldots \ldots$

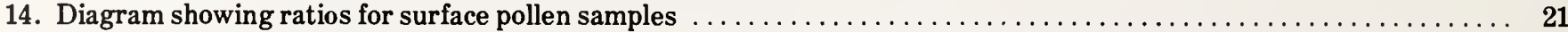

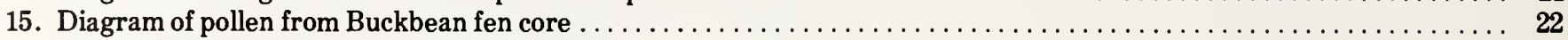

16. Diagrammatic sketch showing relationships between zones, carbon-14 and extrapolated ages, and time stratigraphic

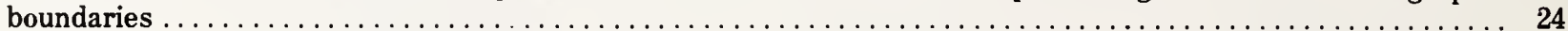

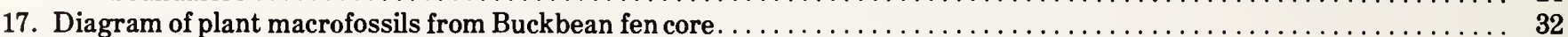

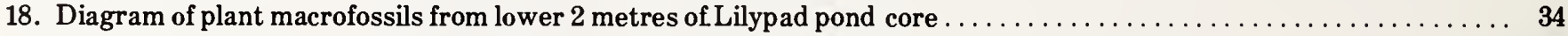

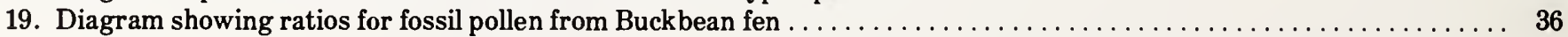

\section{TABLES}

TABLE 1. Scientific names, and common names î available, of plant taxa mentioned in text, tables, and illustrations ....... E7

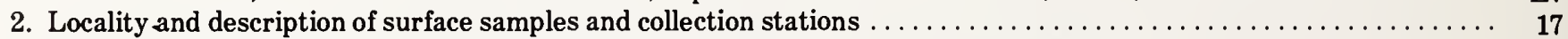

3. Summary of inferred changes in environment at Buckbean fen during the last $12,000+$ years $\ldots \ldots \ldots \ldots$

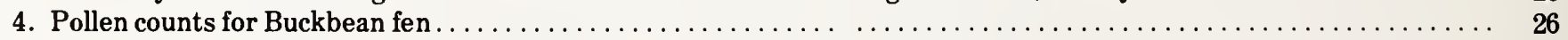

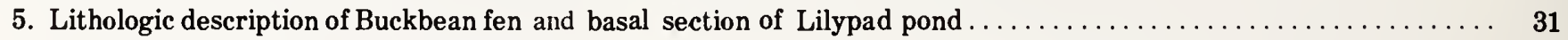

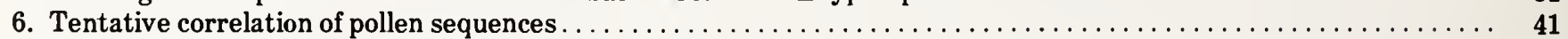

\section{METRIC-ENGLISH EQUIVALENTS}

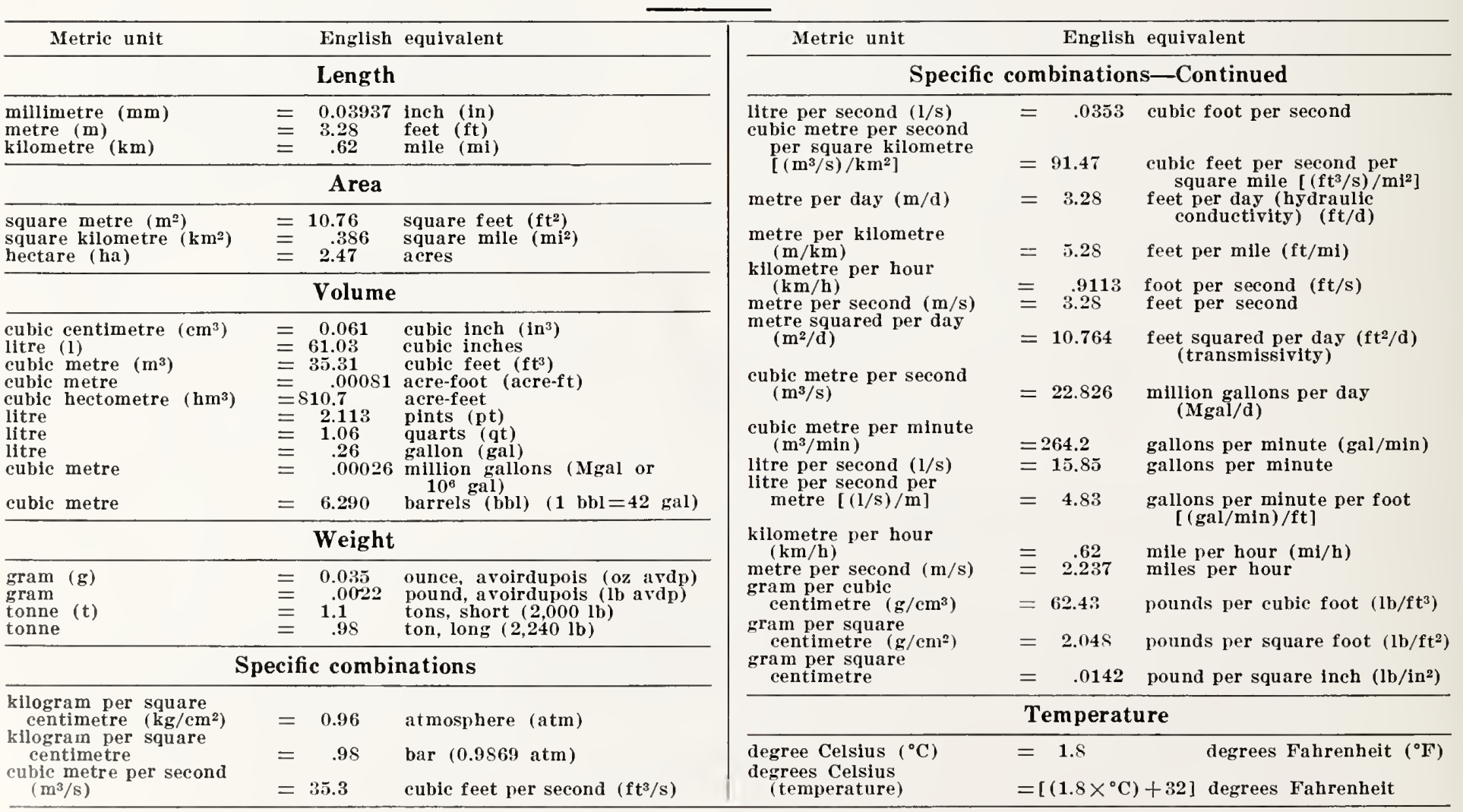




\title{
LATE QUATERNARY VEGETATION HISTORY OF THE YELLOWSTONE LAKE BASIN, WYOMING
}

\author{
By RichaRd G. BAKER
}

\section{ABSTRACT}

A large icecap flowed radially from the Yellowstone Lake basin during Pinedale (late Pleistocene) time. As it melted, kettles, ice-marginal lakes, and associated ice-contact deposits formed between the glacier and the basin sides. With further wasting, lake levels dropped, beaches formed at progressively lower elevations, and lagoons occupied the kettles. A core from Buckbean fen, an abandoned lagoon 15 feet above modern lake level, was analyzed for pollen and seeds. Macrofossils from the base of lagoon sediments in Lilypad pond 40 feet above the lake were also examined.

Surface pollen samples were collected to relate modern pollen rain to vegetation distribution and to aid in the interpretation of fossil pollen spectra. Steppe, Pinus contorta forests, and PiceaAbies-Pinus albicaulis forests can be recognized from their pollen rain. Pollen rain in alpine tundra is similar to that in subalpine parklands, but both are distinct from pollen rain in other vegetation associations. Few data are available from Pseudotsuga forests.

The Buckbean fen core has two pollen zones-a lower zone and an upper zone. The lower zone $(960-770 \mathrm{~cm})$ is characterized by more than 50 percent nonarboreal pollen with maxima of Picea, Abies, Pinus albicaulis, Betula, juniperus, Populus, Graminceae, and Compositae. It has two subzones-the Betula and the Populus. The Betula subzone $(960-875 \mathrm{~cm})$ has a Betula pollen maximum, Betula glandulosa seeds, a few alpine macrofossils, and very rare arboreal macrofossils. This fossil assemblage suggests that the site was about at treeline for some time after the glacier melted and that treeline was about 2,000 feet lower than at present in this part of Yellowstone National Park. The assemblage suggests that the climate was cold and moist. The sediments of the subzone contain too little organic matter for radiocarbon dating, but the base of the subzone is estimated to be about 14,500 years old.

The Populus subzone $(875-770 \mathrm{~cm})$ contains a Populus maximum and common arboreal macrofossils. Betula pollen decreases, but other pollen types remain at nearly constant levels. This subzone marks the invasion of forest in the area and suggests a slightly warmer climate. The top of the Picea-Abies-Pinus albicaulis zone is radiocarbon dated at $11,630 \pm 180$ years B.P. vefore present).

The upper pollen, or Pinus contorta, zone $(770-0 \mathrm{~cm})$ is characterized by Pinus contorta pollen and needles and by $60-85$ percent total Pinus pollen. Three subzones are defined, as follows.

A Pinus contorta-Pinus albicaulis subzone $(770-600 \mathrm{~cm})$ is characterized by pollen and needles of both Pinus albicaulis and Pinus contorta. The two pines apparently grew together locally in the absence of Picea and Abies, which suggests a cool, dry climate. This subzone was deposited from about 11,630 to about 10,160 years B.P.

A Pinus contorta subzone $(600-420 \mathrm{~cm})$ contains high values of pine pollen, mainly lodgepole, and low values of Pinus albicaulis, Picea, and Abies. This subzone includes the Altithermal period, and represents a warmer, drier climate from about 10,160 to about 5,000 years B.P., but a hiatus representing as much as 4,000 years is probably present in this interval.

A Picea-Abies-Pinus contorta subzone ( $420-0 \mathrm{~cm})$, representing about the last 5,000 years, shows a recurrence of Picea and Abies pollen and needles. This is the Neoglacial period, and the pollen suggest a climate that is cooler and moister than during deposition of the preceding subzone.

\section{INTRODUCTION}

The primary purpose of this study was to deduce the vegetation history during the last 13,000 years of the Yellowstone Lake region. Secondary purposes were (1) to infer general climatic changes during this period, and (2) to provide a standard sequence of dated climatic and vegetation changes for correlation with glacial fluctuations.

The fieldwork was carried out in 1966 and 1967 under the supervision of G. M. Richmond, as part of the glacial geology project, Yellowstone National Park study, conducted by the U.S. Geological Survey in cooperation with the National Aeronautics and Space Administration and the National Park Service.

\section{LOCATION AND CLIMATE}

Materials for this study were collected from Yellowstone National Park, northwest Wyoming. Much of the park is a plateau (referred to informally in this report as the Yellowstone plateau) that is $8,000-9,000$ feet above sea level. The Absaroka Range on the eastern margin of the park exceeds 11,000 feet, and isolated peaks in the park exceed 10,000 feet. Fossil pollen samples were collected from depressions near the tip of the Southeast Arm of 
Yellowstone Lake (figs. 1 and 12). The elevation of the coring area is about 7,800 feet, and local relief is as much as 1,500 feet.

The climate of Yellowstone National Park has been summarized by Fletcher (1927a and b) and Lowery ([undated] and 1960). Data from 30-year records for Mammoth (elev 6,241 ft) and Yellowstone Lake (Lake Ranger Station, elev 7,762 ft) are compared with predicted climatic curves (Baker, 1944) in figure 2. Shorter unpublished records from 10 ranger stations are also available from the National Park Service. No climatic recording stations are located in the southeast corner of the park near the coring sites, but generalized maps are available (Lowery, 1960).

Mean annual temperature at Mammoth is $38.9^{\circ} \mathrm{F}$, and at Yellowstone Lake it is $32.8^{\circ} \mathrm{F}$. In summer, the cold water of Yellowstone Lake depresses daytime temperatures along its shoreline (Lowery [undated]), and mean annual temperatures are lower by a few degrees near the lake than elsewhere (Fletcher, 1927a). Mean minimum temperatures for July and January are a few degrees cooler in the Southeast Arm of Yellowstone Lake than at the Lake Ranger Station (Lowery, 1960).

The average annual precipitation recorded in the park increases from less than 14 inches at Lamar Ranger Station in the northeast to 38 inches at Bechler River Ranger Station in the southwest (National Park Service, unpub. data). The coring area receives about 32 inches per year (Lowery, 1960). Unlike any other area in the Rocky Mountain region, Yellowstone National Park has precipitation rather evenly distributed throughout the year (Baker, 1944). At

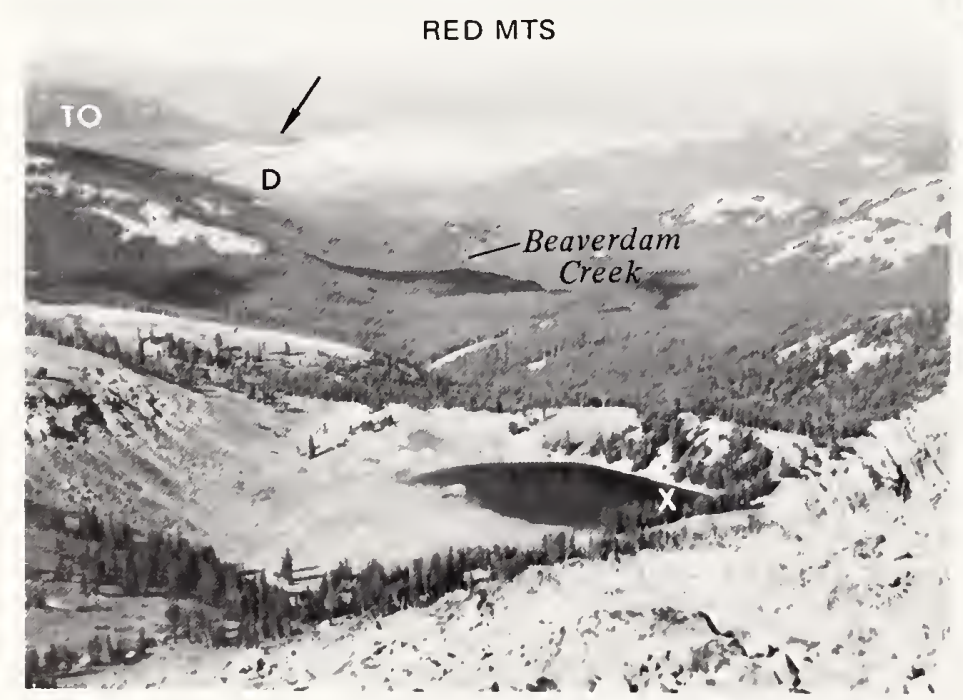

Figure 1.-Southeast Arm of Yellowstone Lake, viewed to the west from Absaroka Range showing coring area. D, Yellowstone River delta; TO, Two Ocean Plateau. Arrow indicates coring area; $X$, surface sample locality SS -38 . Lake in foreground is dammed by a moraine of late Pinedale age.
Mammoth and Yellowstone Lake, precipitation averages about $1-2$ inches every month.

Snowfall ranges in amount from less than 100 inches at lower elevations to well over 200 inches (locally about 400 inches) at higher elevations (Lowery [undated]). Snowfall in the coring area is probably close to 200 inches per year (Fletcher, 1927a).

Summers in the park tend to be sunny, with $65-75$ percent sunshine, and winters more cloudy, with an average of 40 percent sunshine (Lowery [undated]). Prevailing wind directions at Mammoth are southwesterly throughout the year (Fletcher, 1927a). No wind records are available from around the lake.

\section{ACKNOWLEDGMENTS}

John Good, former Chief Naturalist, Yellowstone National Park, granted permission to use an unpublished map of the vegetation of the park as source material for the map published herein. Robert Morey and W. F. White, National Park Service, extended many courtesies while I was in the field. William Hendrickson, Research Biologist, National Park Service, provided advice and information on the climate and vegetation of the park. W. A. Weber, University of Colorado, identified plants and cooperated in the assembly of the seed collection of the University of Colorado Herbarium. This paper is the outgrowth of a $\mathrm{Ph}$. D. dissertation, and W.C. Bradley and P.W. Birkeland, University of Colorado, and Robert Tschudy, U.S. Geological Survey, offered many helpful suggestions during the preparation of the manuscript. Special thanks are extended to E.B. Leopold, for making available the facilities of the palynology laboratory of the U.S. Geological Survey, to Meyer Rubin, for radiocarbon dating a number of samples from critical levels in the cores, and to W.C. Bradley, who served as my dissertation advisor. The final year of support came from National Science Foundation grant B-81590 to E. B. Leopold.

\section{METHODS OF STUDY}

For the purpose of this study, cores for pollen and plant-macrofossil analysis were taken from four abandoned lagoons of Yellowstone Lake. During and after the melting of the last Pleistocene icecap in the Yellowstone Lake basin, the successively lower lake levels left a series of shorelines between 220 feet and the present lake level (Richmond, 1969c) (figs. 3 and 4). Open lagoons associated with the old shorelines were abandoned as the lake fell and were left as isolated, shallow ponds. The ponds gradually filled with sediment and are now covered with semiaquatic vegetation. Cores were taken from lagoons at eleva- 

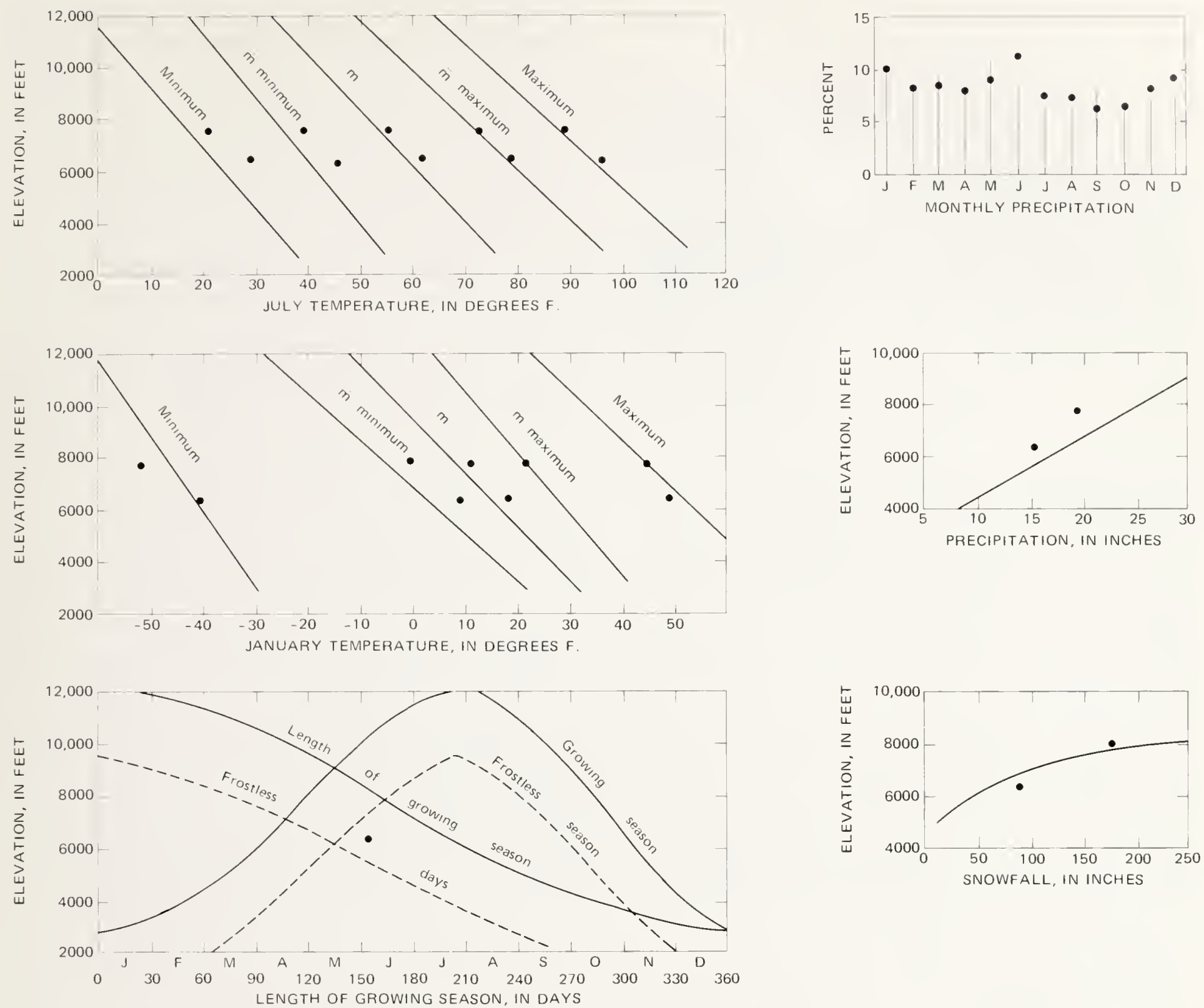

Figure 2.-Summary of climatic data (dots) for Yellowstone National Park compared with predicted climatic curves (lines). Dots at 6,241foot elevation are data for Mammoth; dots at 7,762-foot elevation are data for Yellowstone Lake (Lake Ranger Station). (From F. S. Baker, 1944; data from Becker and Alyea, 1964a and b, Lowery, [undated] and 1960.)

tions of $90,40,25$, and 15 feet above modern lake level. The core from the 15-foot lagoon (here informally called Buckbean fen) contained the most complete sequence and was selected for detailed pollen and seed analysis. Macrofossils from the basal 2 $\mathrm{m}$ of the 40-foot lagoon (here informally called Lilypad pond) are shown in a separate diagram and correlated with the bottom $2 \mathrm{~m}$ of the Buckbean fen core.

The pollen assemblages represent mainly upland plants whose pollen was produced in large quantities, was efficiently dispersed, and was well preserved. Analysis provided information on regional vegetation patterns down to the level of families or selected genera. Species and even some genera cannot be established from pollen alone. Some of the pollen types apparently blew in from considerable distances. Study of plant macrofossils (seeds, fruits, bracts, leaves, flowers, twigs, and cone scales) provided information on local vegetation, usually to the level of species. The pollen and macrofossil data that show changes in vegetation through time are plotted in figures 15 and 17. Radiocarbon dates on organic material from the core, which show the ages at four levels in the core, are also plotted in figures 15 and 17. Studies of modern vegetation and pollen rain in Yellowstone National Park were important aids in interpreting past vegetation. Modern vegetation associations, with increasing elevation, are Artemisia 


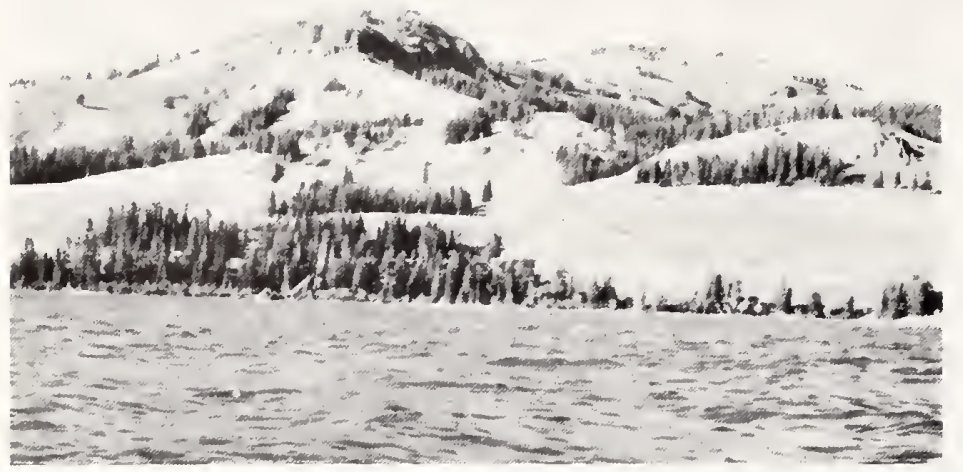

Figure 3.-Shorelines above Southeast Arm of Yellowstone Lake. Lower benches are $110,90,60$, and 25 feet above the lake; higher benches are kame terraces or rock surfaces. View is to the northeast.

steppe, Pseudotsuga forest, Pinus contorta forest, Picea-Abies-Pinus albicaulis forest, and alpine tundra. A generalized vegetation map of the southeast corner of Yellowstone National Park (fig. 6) was made from field observations, topographic maps, and an unpublished vegetation map by the National Park Service. In addition, a reconnaissance map was made of local vegetation types around the coring sites (fig. 7).

The coring sites are located near the boundary between two vegetation types (fig. 7). Pinus contorta forests occupy lower, drier areas, and PiceaAbies-Pinus albicaulis forests extend up northfacing slopes to the Two Ocean Plateau (fig. 7). Past climatic fluctuations caused this boundary to migrate across the coring sites, and these migrations are recorded in the pollen macrofossil sequences.

Modern pollen was analyzed from surface sediments in ponds situated in the major vegetation associations and the data were plotted (fig. 13). Pollen rain from most associations is sufficiently distinctive to allow its recognition in fossil pollen assemblages. Some fossil assemblages do not match any modern samples, however, and these may represent ancient vegetation associations not now present in the Yellowstone National Park area.

Elevational limits of modern vegetation associations are controlled by climate, but precise relationships are still poorly known. Where the distributional limits of certain plant taxa are found to coincide with a specific mean temperature, past distributional limits of those taxa may suggest paleotemperatures (Wolfe and Leopold, 1967). This approach must be used with caution because the coincidence may not be simply a cause-and-effect relationship. In this study only broad climatic changes can be inferred from most of the past vegetation changes.

Glacial deposits and topographic features of late Quaternary age in Yellowstone National Park have been mapped by G. M. Richmond, K. L. Pierce, and H. A. Waldrop (U.S. Geological Survey, 1972). Radiocarbon dates suggest that the Pinedale Glaciation began after $27,000 \pm 800$ years ago in nearby Jackson Hole, Wyo. (Levin and others, 1965). Pinedale glaciers had retreated extensively by about 13,000 years ago in Yellowstone National Park

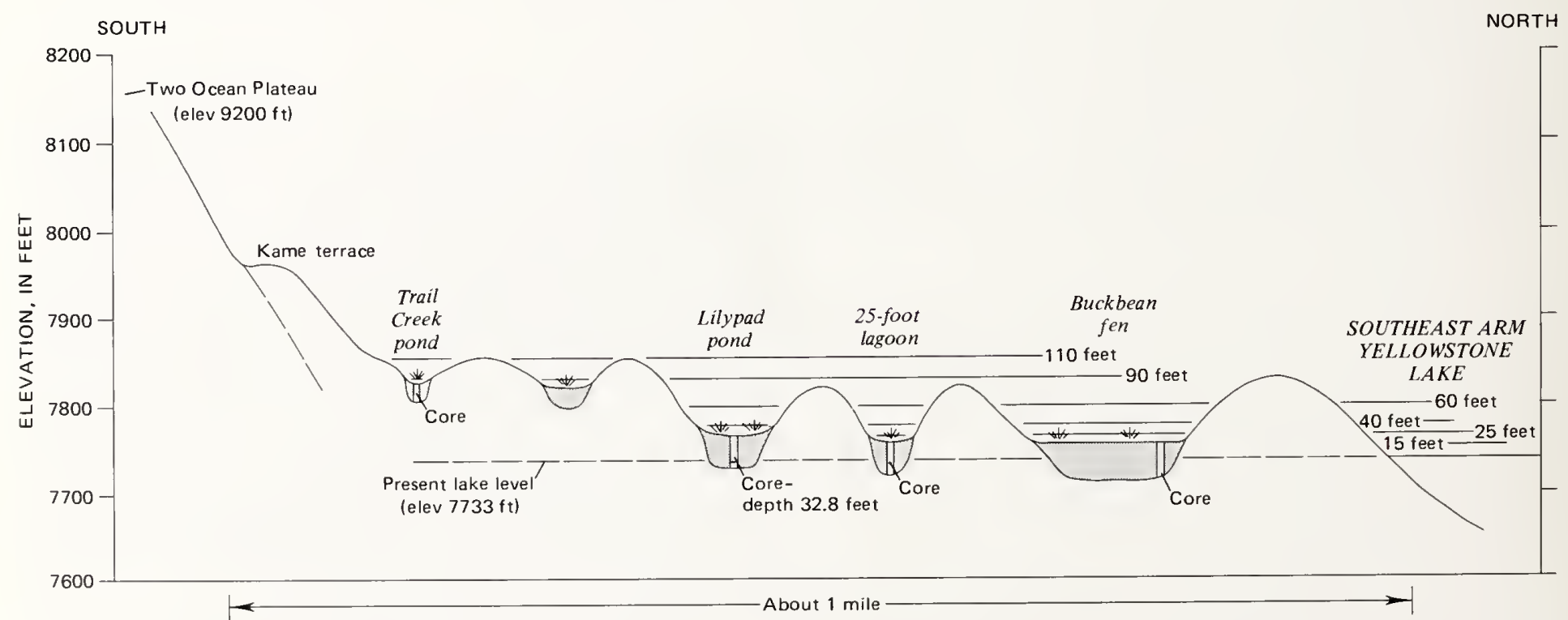

FIGURE 4.-Schematic cross section showing relationship between Two Ocean Plateau, the filled lagoons, the lake levels, and the coring sites. See figure 7 for location of ponds. 
(Richmond, 1970b; Bender and others, 1971). Dates on glacial advances elsewhere in the western cordillera (Richmond, 1965, 1970b; Porter and Denton, 1967) correlate well with cool, moist periods inferred from my paleobotanical record and support geomorphic and soil-stratigraphic correlation of the Yellowstone glacial deposits with the standard Rocky Mountain glacial sequence (Richmond, 1965).

Our knowledge of late Quaternary regional climatic changes is still sketchy. This study provides new data in an area heretofore unstudied. More data of this sort will contribute answers to questions such as the following: How synchronous were regional climatic changes? Were climatic changes similar in nature from one region to another?

\section{GLACIAL HISTORY}

Yellowstone National Park was glaciated several times during early and mid-Quaternary time (Richmond, 1969c, 1970a). Glacial till underlies an ash-flow tuff about 600,000 years old near Tower Falls (U.S. Geological Survey, 1972) and midQuaternary sections containing glacial deposits are known from scattered sections elsewhere in the park.

The Bull Lake Glaciation is the oldest glaciation that has extensive till and constructional topographic features remaining. The Bull Lake icecap was somewhat larger than the succeeding Pinedale icecap, and large areas underlain by Bull Lake Till are found in the western part of the park (U.S. Geological Survey, 1972). Bull Lake Till underlies wood-bearing lake sediments dated at greater than 42,000 years B.P. (before present) and greater than 45,000 years B.P. in the Yellowstone Lake basin (Richmond, 1969c, 1970a).

Pinedale Glaciation is estimated to have begun about 25,000 years ago and stagnated about $14,500-13,000$ years ago in the Yellowstone National Park region (Richmond, 1970a, b; Waddington and Wright, 1974). The Pinedale icecap centered along a north-south axis through Yellowstone Lake (Richmond and Pierce, 1968, 1972; Richmond, 1969c). Ice flowed radially from the lake area to the north, to the east through divides in the Absaroka Range, and to the south and southwest across the rugged plateaus and ridges. As the Pinedale icecap melted, local ice-marginal lakes and kame terraces formed in the northeastern part of the Yellowstone Lake basin and gradually extended southward (Richmond, 1969a; U.S. Geological Survey, 1972). Channels carried the melt water away from the basin at several points around the lake (Richmond, 1969a). In the coring area a kame terrace formed along the lower slopes at the northwest margin of the Two Ocean Plateau (fig. 5, phase 1). Later, large ice blocks calved off, became buried by outwash and lake sediments, and formed kettles approximately parallel to the ice margin (locations shown in fig. 5, phase 2).

After the Pinedale icecap had melted, cirque and valley glaciers readvanced in the Absaroka Range and on the Two Ocean Plateau (Richmond and Pierce, 1972). Some valley glaciers were 5 miles long, and their terminal moraines (fig. 1) reached elevations as low as 7,880 feet, but averaged 8,400 feet (Richmond, 1969b). Outwash terraces extended from these moraines down the valleys to a level about 60 feet above Yellowstone Lake. Lake sediments beneath a delta that graded to the 60 -foot level at Grouse Creek on the South Arm of Yellowstone Lake were dated at $9,060 \pm 300$ years B.P. (Sullivan and others, 1970, sample W-2041; Richmond, 1970a). The coring sites were not glaciated and apparently received no glacierderived sediments at this time.

An interval of maximum warmth and dryness (the Altithermal interval) is recognized in the Rocky Mountain area following the retreat of late Pinedale ice (Richmond, 1965, p. 227). Antevs (1955) placed the Altithermal interval between 7,500 and 4,000 years B.P.; however, these boundaries have not been consistently used, and they may transgress time. Valley and cirque glaciers apparently retreated during this warm period.

Neoglaciation is the period of glacier expansion following the Altithermal period and extending to the present time. In the Rocky Mountain region it has been divided into the Temple Lake Stade, thought to have formed moraines about 2,800 years B.P. (Richmond, 1969b), and the Gannett Peak Stade, which began about 700 years ago and continues to the present (Porter and Denton, 1967, p. 201). Recently, however, Birkeland and Miller (1973), Miller and Birkeland (1974), and Currey (1974) showed that the type section of the Temple Lake in the Wind River Range is pre-Altithermal and may be late Pinedale in age. A new type section and name should be chosen for this 2,800-year-old glacial advance. Hence, the report will use the term "early neoglacial," rather than "Temple Lakes." In the Absaroka Range the average elevation is 9,460 feet for early neoglacial end moraines and 9,845 feet for Gannett Peak end moraines (Richmond, 1969b).

Recent evidence suggests that some areas experienced glacial expansion as early as 5,000 years ago (Porter and Denton, 1967, p. 198). No moraines of this age are recognized in Yellowstone National Park, 
but radiocarbon dates are lacking. The pollen record suggests that post-Altithermal cooling began at about that time. Neoglaciation in the park could thus include all sediments younger than 5,000 years. This usage is consistent with a recent definition of Neoglaciation (Porter and Denton, 1967, p. 205): "We *** define Neoglaciation as the climatic episode characterized by rebirth and/or growth of glaciers following maximum shrinkage during the Hypsithermal (Altithermal) interval." Neoglaciation is a geologic-climate unit. Boundaries of such units need not be isochronous (Am. Comm. Strat. Nomenclature, 1961, p. 660). Nearly continuous shorelines that locally grade into kame deposits are found around the south shore of
Yellowstone Lake at about 110 and 90 feet above modern lake level. The rarity at these levels of spits and bars, whose formation depends on a large fetch, suggests that the lake was not entirely open at this time (Richmond, 1969a). The 110-foot shoreline is not preserved in the coring area, but Trail Creek pond was a shallow lagoon that formed behind the 90 -foot beach (fig. 5, phase 2, and fig. 7). Peat from this lagoon is $10,360 \pm 350$ years B.P. (sample $W-2289$ ). The 90 -foot lake level is probably older than this date because the peat sampled lies an undetermined distance above the basal organic sediments, and the break between sand of the lagoon floor and basal organic sediments may represent a diastem. This

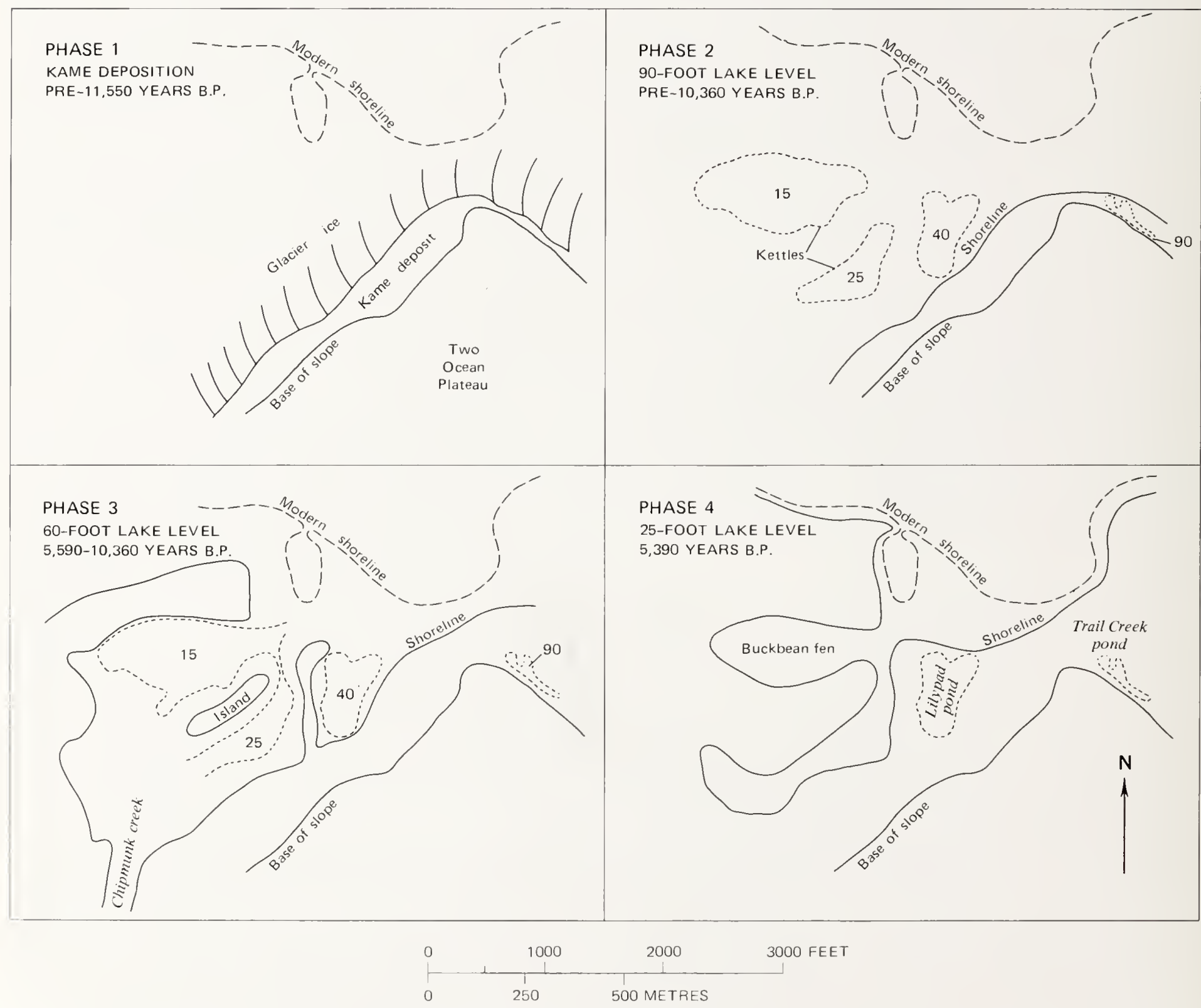

Figure 5.-Geomorphic development of coring area as glacier ice melted and lake level fell. Numbers in kettles indicate height of "baymouth bars," in feet above present lake level, that protected the lagoons and controlled their formation. 
90-foot lagoon probably formed during retreat of middle Pinedale ice; the organic sediment may have formed in part during the late Pinedale advance.

Lower shorelines at $60,40,25,15,10$, and 5 feet above modern lake level have associated large spits, bars, and lagoons similar in size to modern ones. Richmond (1969a) concluded that these lower beaches formed in an open, ice-free Yellowstone Lake after the icecap had entirely melted because the lower shorelines are cut into kame deposits and do not grade into them.

The 60 -foot shoreline correlates with a glacial advance (late Pinedale of Richmond, 1970b; Birkeland and others, 1971) that ended about 9,000 years B.P. in Yellowstone National Park. When the lake was at the 60 -foot level, rims of kettles must have projected above water to form isolated bays in the coring area (fig. 5, phase 3).

Subsequent lowering of lake level converted Lilypad pond, Buckbean fen, and other kettles to lagoons and finally to isolated ponds (fig. 5 , phase 4). Radiocarbon dates of $5,590 \pm 250$ years B.P. (sample W - 2286) from Lilypad pond and $5,390 \pm 250$ years $B$. P. ( sample $W-2281$ ) from Buckbean fen indicate that lake level had fallen below these lagoons before about 5,500 years ago. The late Pinedale and younger levels were apparently controlled by erosion of glacial drift along the Yellowstone River (Richmond, 1969a).

\section{VEGETATION OF YELLOWSTONE NATIONAL PARK AND SURROUNDING AREA}

Yellowstone National Park has distinct elevational zonation of vegetation similar to that of other parts of the Rocky Mountain region (Daubenmire, 1943). Five broad vegetation zones, herein called vegetation associations, are briefly discussed. Scientific names of plants, and common names if available, are listed in table 1.

TABLE 1.-Scientific names, and common names if available, of plant taxa mentioned in text, tables, and illustrations

[(p), pollen or spores of the taxon were found; (m), macrofossils of the taxon were found

Scientific name and author

Common name, if available

DIVISION CHOLOROPHYTA

HYDRODICTYACEAE

(m) Pediastrum

DIVISION CHAROPHYTA

CHARACEAE

(m) Chara

DIVISION BRYOPHYTA-.................... Mosses
TABLE 1.-Scientific names, and common names if available, of plant taxa mentioned in text, tables, and illustrations-Continued

Scientific name and author

Common name, if available

DIVISION BRYOPHYTA-Continued

AULACOMNIACEAE

(m) Aulacomnium palustre (W. \& M.) Schw.

HYPNACEAE

Climacium dendroides

(Hedw.) W. \& M.

(m) Drepanocladus

LESKEACEAE

Helodium blandowii

(W. \& M.) Warnst.

SPHAGNACEAE

(m) Sphagnum

(m?) Sphagnum warnstorfianum

Dr.

DIVISION PTERIDOPHYTES

EQUISETACEAE

(p) Equisetum ................... Horsetail

ISOËTACEAE

Isoëtes

Quillwort

SELAGINELLACEAE

(p) Selaginella densa Rydb...- Rock selaginella Selaginella selaginoides

(L.) Link

POLYPODIACEAE

(p)

Fern

DIVISION SPERMATOPHYTA

CUPRESSACEAE

(p) Juniperus

(p)?(m)Juniperus communis L. --- Common juniper Juniperus virginiana $\mathrm{L}$. var. scopulorum Lemmon

Redcedar, Rocky Mountain juniper

PINACEAE

(p) (m) Abies lasiocarpa (Hook.) Nutt.

(p) (m) Picea engelmannii (Parry) Engelm. Picea pungens Engelm. -.-

(p) (m) Pinus albicaulis Engelm. -(p) (m) Pinus contorta Dougl. -....

(p)? Pinus flexilis James -........

(p)? Pinus ponderosa Laws.-...

(p) (m) Pseudotsuga menziesii (Mirb.) Franco-.......-.- Douglas-fir

(p) Tsuga heterophylla (Rafn.) Sarg. ............... Western hemlock

(p) Tsuga mertensiana (Bong.) Carr.

Mountain hemlock

\section{EPHEDRACEAE}

(p) Ephedra torreyana S. Wats.

(p) Ephedra viridis Coville---- Green jointfir ACERACEAE

(p) Acer -.......................... Maple

(p) AMARANTHACEAE

BETULACEAE

(p) (m) Alnus tenuifolia Nutt. ....- Thinleaf alder 
TABLE 1.-Scientific names, and common names if available, of plant taxa mentioned in text, tables, and illustrations-Continued

Scientific name and author

Common name, if available

DIVISION SPERMATOPHYTA-Continued

BETULACEAE-Continued

(p) Betula -................... Birch

(p) (m) Betula glandulosa

Michx.

(p)? Betula occidentalis

Hook.

BORAGINACEAE

Mertensia

Bog birch

River birch

CALLITRICHACEAE

Callitriche

CAMPANULACEAE

Campanula rotundifolia

L. -....

\section{CAPR}

(p)

(p) CARYOPHYLLACEAE

CERATOPHYLLACEAE

(m) Ceratophyllum demersum

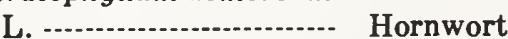

(p) CHENOPODIACEAE
(p)? Atriplex sp
Saltbush
(p) Sarcobatus vermiculatus
(Hook.) Torr.

Bluebell,

chiming bells

Water-starwort

Common harebell

Honeysuckle family

(p) CHENOPODIACEAE

AMARANTHACEAE ................ Cheno-Ams

COMPOSITAE

(p) Subfamily Tubuliflorae

Achillea lanulosa Nutt.---- Yarrow

(p) Ambrosia

Antennaria --.--.--.--...... Pussytoes

(p) Artemisia

(p) Artemisia tridentata

Nutt.

Aster

Chrysothamnus

(p)? Franseria

(p) Subfamily Liguliflorae

CRASSULACEAE

Sedum lanceolatum Torr. Stonecrop

(m) Sedum rhodanthum Gray Rosecrown

Sedum rosea (L.) Scop. ssp. integrifolium (Raf.)

Hultén

Kings Crown

(p) CRUCIFERAE

Arabis

Arabis glabra (L.) Bernh.

Rockcress

Tower mustard

(m) Descurainia californica

(A. Gray) Schulz ......... Tansymustard

(m) Rorippa islandica (Oeder)

Borbas -.......-..-.-.-- Marshcress

\section{ELEAGNACEAE}

(p) Shepherdia canadensis

\section{ERICACEAE}

(L.) Nutt.

Arctostaphylos uva-ursi

(L.) Spreng.
TABLE 1.-Scientific names, and common names if available, of plant taxa mentioned in text, table, and illustrations-Continued

Scientific name and author

Common name, if available

DIVISION SPERMATOPHYTA-Continued

ERICACEAE-Continued

Kalmia polifolia Wang. ---- Swamp laurel

Ledum glandulosum

Nutt.

Phyllodoce empetriformis

(Smith) D. Don -..........

FAGACEAE

(p) Quercus -..................... Oak

GENTIANACEAE

Gentianopsis thermalis

(O. Kuntze) Iltis

(=Gentiana thermalis

Kuntze)

Mountainheath

Myrtle blueberry

Rocky Mountain
fringed gentian

HALORAGACEAE

(m) Myriophyllum

(m)? Myriophyllum spicatum $\mathrm{L}$. ssp. exalbescens (Fern.)

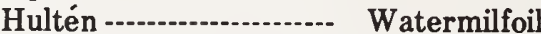

(m)? Myriophyllum verticillatum
Greenmilfoil

HYDROPHYLLACEAE

Phacelia

JUGLANDACEAE

(p) Juglans

(p) LEGUMINOSAE

Lupinus argenteus Pursh.

LENTIBULARIACEAE

Utricularia minor L.......-. Small bladderwort

Utricularia vulgaris L..... Common bladderwort

LORANTHACEAE

(p) Arceuthobium

(p)? Arceuthobium americanum

Nutt.

Lodgepole pine dwarf mistletoe

Arceuthobium campylopodum Engelm

Western dwarf mistletoe

Arceuthobium douglasii

Engelm.

Douglas-fir dwarf mistletoe

MENYANTHACEAE

(p) (m) Menyanthes trifoliata L. -- Buckbean

NYMPHAEACEAE

(p) (m) Nuphar luteum

Sibth. \& Sm. ssp.

polysepalum (Engelm.)

OLEACEAE Beal-

Yellow pond lily

(p) Fraxinus

Ash

(p) ONAGRACEAE
(m)? Epilobium adenocaulon Hausskn.
(m)? Epilobium glandulosum Lehm.
(m) Epilobium lactiflorum Hausskn.

Pale willow-herb 
TABLE 1-Scientific names, and common names if available, of plant taxa mentioned in text, tables, and illustrations-Continued

Scientific name and author

Common name, if available

DIVISION SPERMATOPHYTA-Continued

PLATAGINACEAE

(p) Plantago

POLEMONIACEAE

Phlox multiflora

A. Nels.

POLYGONACEAE

(p) Bistorta

(p) Bistorta bistortoides

(Pursh.) Small (=Poly-

gonum bistortoides

Pursh)

Plantain

(p)? Bistorta vivipara (L.)
S. Gray (=Polygonum

viviparum L.) -.-.---.--- Viviparous bistort

(p) Eriogonum-.................... Umbrellaplant

(p) Koenigia islandica L.

(p) Oxyria

(p)? Persicaria amphibia (L.)

$$
\begin{aligned}
& \text { S. Gray } \\
& \text { (= Polygonum amphibium } \\
& \text { L.) }
\end{aligned}
$$

(p)? Persicara maculata (Raf.)
S. Gray
(=Polygonum persicaria L.)
Ladysthumb

(p)? Polygonum ramosissimum Michx.

(p) Rumex

(p)?(m)Rumex fueginus Phil. -...-(=Rumex maritimus $\mathrm{L}$. var. fueginus (Phil.) Dusen)

Rumex paucifolius Nutt.

(p)?(m)Rumex salicifolius Weinm. ssp. triangulivalvis Danser

RANUNCULACEAE

Aconitum columbianum

Nutt.

Anemone multifida Pair. var. globosa (Nutt.)

T \& G.

(p) Ranunculus

(m) Ranunculus aquatilis L. ---

(p) Thalictrum-......-.........-..RHAMNACEAE

(p)? Ceanothus velutinus

(p) ROSACEAE

$$
\text { Dougl. }
$$

(p)? Cercocarpus

Fragaria

Geum macrophyllum

Willd.

Pentaphylloides floribunda

(Pursh) A. Love -........-

(=Potentilla fruticosa L.)

Alpine sorrel

Water smartweed

Bushy knotweed

Dock

Golden dock

Willow dock

Monkshood

Globose anemone

Water crowfoot

Meadow rue

Sticky-laurel

Mountainmahogany

Strawberry

\section{Large-leaf avens}

Shrubby cinquefoil

(m)? Potentilla biennis Greene

(m)? Potentilla gracilis Dougl.

ex. Hook

Soft cinquefoil
TABLE 1.-Scientific names, and common names if available, of plant taxa mentioned in text, tables, and illustrations-Continued

Scientific name and author

Common name, if available

DIVISION SPERMATOPHYTA-Continued

(p) ROSACEAE-Continued

(m)? Potentilla norvegica L. ---- Norway cinquefoil

(p)?(m)Potentilla palustris (L.)

Scop.

(m) Sibbaldia procumbens L. RUBIACEAE

SALICACEAE

Galium trifidum L.

Marsh cinquefoil

(p) Populus

(p)?(m)Populus balsamifera L. -..Populus tremuloides Michx.

Populus trichocarpa

Torr. and Gray

(p) Salix

Salix arctica Pallas.

Salix ligulifolia (Ball) Ball

(m)? Salix subcoerulea Piper -.- Blue willow

SAXIFRAGACEAE

(m) Saxifraga caespitosa L.--.- Matted saxifrage

(m) Saxifraga rhomboidea Greene

\section{Diamondleaf} saxifrage

(p)? SCROPHULARIACEAE

(p)? Pedicularis

Pedicularis groenlandica

Retz

Elephantella

(p)? Mimulus --.-.-.-.-.-.-.-. Monkey flower

(p) UMBELLIFERAE

URTICACEAE

(p) Urtica

Nettle

(p) CYPERACEAE

(m) Carex aquatilis Wahlenb.

(m) Carex canescens L.

(m) Carex diandra Schrank

Carex geyeri Boott

Carex hoodii Boott

(m) Carex limosa L.

Carex phaeocephala Piper

(m) Carex utriculata Boott

(=Carex rostrata Stokes)

(m) Carex vesicaria L.

(m) Eleocharis macrostachya

Britt.

Eriophorum

Scirpus acutus Muhl

(p) GRAMINEAE

Agropyron --.---.--.---.--.-- Wheatgrass

Bromus --.-.-.-.......... Bromegrass

Bromus inermis Leyss. ...- Smooth brome

Calamagrostis canadensis

(Michx.) Beauv. -------.- Bluejointgrass

Calamagrostis inexpansa

A. Gray -................-.-. Northern reedgrass

Deschampsia caespitosa

(L.) Beauv

Elymus

Tufted hairgrass

Glyceria borealis (Nash)

Batchelder Wild-rye

Northern mannagrass 
TABLE 1.-Scientific names, and common names if available, of plant taxa mentioned in text, tables, and illustrations-Continued

Scientific name and author

Common name, if available

DIVISION SPERMATOPHYTA-Continued

(p) GRAMINEAE-Continued

(m) Glyceria maxima (Hartm.)

Holmb. ssp. grandis

(Wats.) Hulten

(=Glyceria grandis

S. Wats.) -

Poa

Sitanion longifolium J. G.

Smith

(=Sitanion hystrix

(Nutt.) J. G. Smith)

JUNCACEAE

Stipa

Luzula parviflora (Ehrh.)

Desv.

NAIADACEAE

Luzula spicata (L.) DC..--- Spike woodrush

(m) Naias flexilis (Willd.)

Rostk. and Schmidt ..... Naiad

(m) Potamogeton alpinus

Balbis -...-................ Northern pondweed

(m) Potamogeton filiformis

Pers.

(m) Potamogeton gramineus $\mathrm{L}$.

(m)? Potamogeton illinoensis

Morong

Potamogeton pectinatus

L.

Potamogeton vaginatus

Turcz.

SPARGANIACEAE

(p)? Sparganium

Sparganium angusti-

folium Michx.

Burreed

Sparganium minimum

TYPHACEAE

(p)? Typha angustifolia L. --..-- Narrowleafed cattail

(p) Typha latifolia L............. Broadleaf cattail

\section{REGIONAL VEGETATION}

ARTEMISIA STEPPE ASSOCIATION

The lowest vegetation type in the park is Artemisia (sagebrush) steppe at the base of the north edge of the Yellowstone plateau (fig. 6). Artemisia tridentata is the dominant plant in this association, but Sarcobatus vermiculatus (greasewood) and Atriplex spp. (saltbush) are common on clayey or alkaline sites, and in many places Chrysothamnus spp. are scattered among the sagebrush. Grasses including Elymus spp. (wild-rye) and Bromus spp. (bromegrass) are locally common. This type occurs between Mammoth and Gardiner in the northern part of the park and is common around the margins of the park below about
6,000 feet. Large areas of Artemisia steppe on the Snake River Plain southwest of the park may be an important source of Artemisia pollen.

The lower limit of trees above the Artemisia steppe is highly variable because of local factors. Near Mammoth, it ranges from about 5,800 to 6,800 feet. East of the park in the rain shadow of the Absaroka Range it is 6,500-7,600 feet $(\mathrm{H}$. E. Wright Jr., unpub. data, 1967). At Mammoth it is associated with a mean annual temperature of about $40^{\circ} \mathrm{F}$, mean January temperature of $18^{\circ} \mathrm{F}$, mean July temperature of $63^{\circ} \mathrm{F}$, and mean annual precipitation of 15.5 inches.

Artemisia tridentata (big sagebrush) also dominates in forest openings up to several acres in size on the Yellowstone plateau, where it is more stunted than at lower elevations. In the southeast corner of the park, these Artemisia openings occur on dry south-facing slopes adjacent to the Southeast Arm of Yellowstone Lake (fig. 3). They occur locally on south-facing slopes of Buckbean fen and adjacent lagoons (fig. 7).

Plants associated with Artemisia in the southeast part of the park include Eriogonum subalpinum (umbrellaplant), Lupinus argenteus (silvery lupine), Achillea lanulosa (yarrow), Antennaria sp. (pussytoes), Phacelia sp. (scorpion-weed), Arabis glabra (rockcress), Phlox multiflora (common phlox), Carex hoodii (sedge), Carex petasata (sedge), Agropyron spp. (wheatgrass), Stipa spp. (needlegrass), Bromus inermis (bromegrass), Campanula rotundifolia (common harebell), Sitanion hystrix (squirrel-tail), and Arctostaphylos uva-ursi (kinnikinnick). Artemisia tridentata in this community may have been an important supplier of Artemisia pollen in the fossil record.

\section{PSEUDOTSUGA ASSOCIATION}

Pseudotsuga menziesii (Douglas-fir) is dominant in the next lowest vegetation association but is sporadic in occurrence in the Yellowstone region. Locally Pinus flexilis (limber pine) and Populus tremuloides (quaking aspen) are common in this association. Pinus ponderosa (ponderosa pine), which normally occurs in this elevational zone, is not present in northwestern Wyoming (Choate, 1963). Juniperus virginiana var. scopulorum (Rocky Mountain juniper) occurs at lower elevations along the forest-steppe boundary. Pseudotsuga menziesii is not common on the Yellowstone plateau, but it grows sparsely about 6 miles north of the coring sites and on the east slope of the Absaroka Range about 12 miles to the east.

The Pseudotsuga association grows as low as 6,000 feet in an open savanna, along stream valleys, and in closed forests as high as about 8,000 feet $(H$. E. 

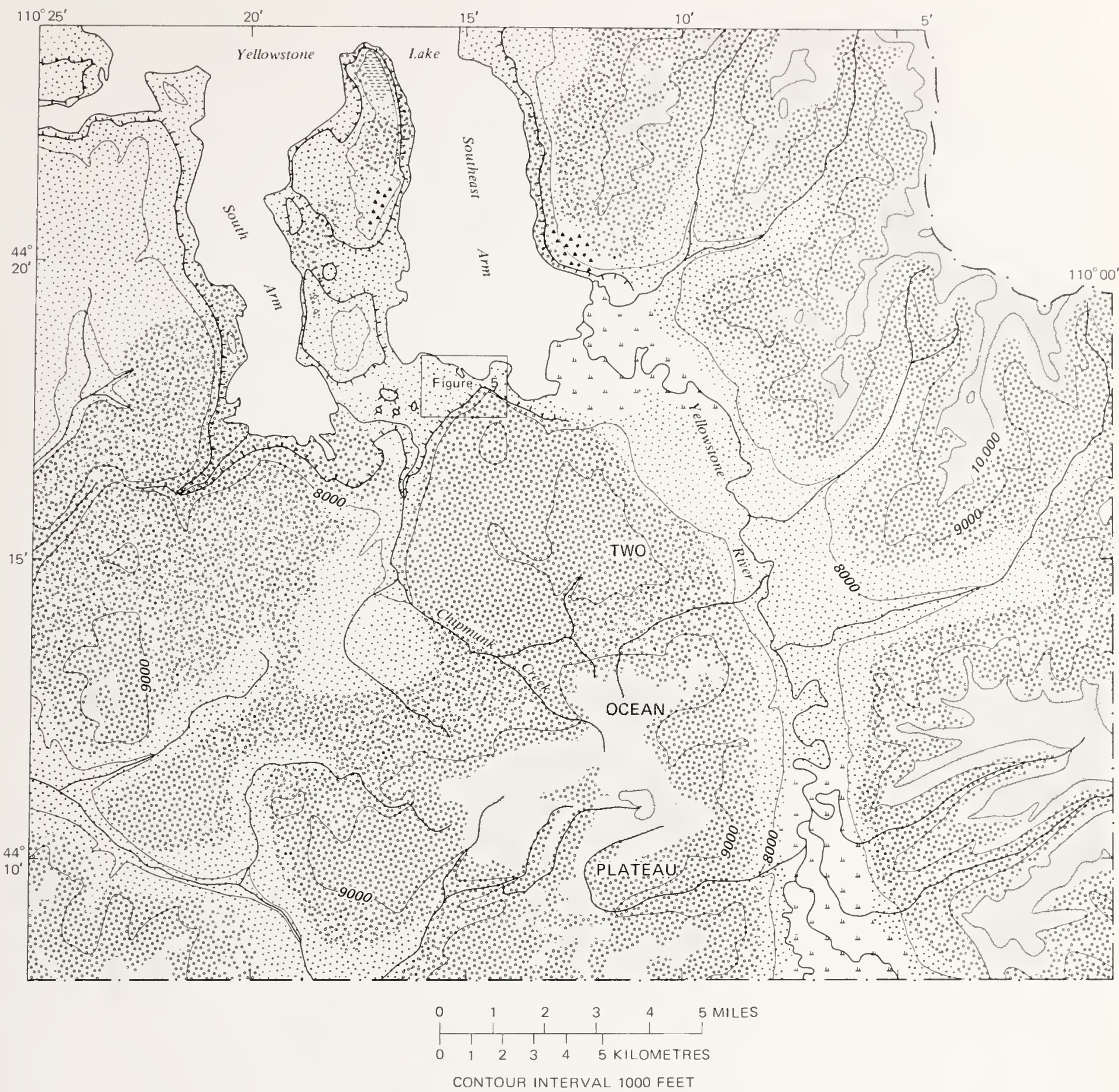

EXPLANATION
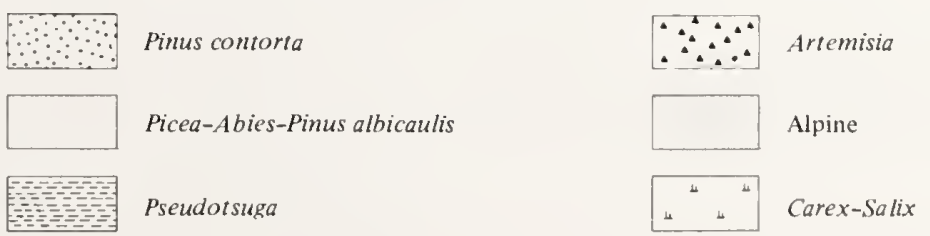

FIGURE 6. - Vegetation map of the southeast corner of Yellowstone National Park. The hachured line is 110 feet above Yellowstone Lake; it shows the highest lake level interpolated from the base maps. Contacts between vegetation units are approximate and are not marked by lines. In part from unpublished map of vegetation of Yellowstone National Park by National Park Service. Base from U.S. Geological Survey Eagle Peak, Frank Island, Mount Hancock, and Two Ocean Pass 1:62,500 topographic quadrangles, 1959. 
Wright Jr., unpub. data, 1973). No climatological data were available for this association.

\section{PINUS CONTORTA FOREST ASSOCIATION}

The Pinus contorta (lodgepole pine) forest is by far the most common vegetation type in Yellowstone National Park. It covers about 80 percent of the total forested area (National Park Service, unpub. data). Picea engelmannii (Engelmann spruce) and Abies lasiocarpa (subalpine fir) grow in the upper part of this type. Most Pinus contorta forests are open and dry and contain little underbrush, and they commonly grow on porous grus soils. Near the coring sites the common understory plants are Juniperus communis (common juniper), Shepherdia canadensis (buffaloberry), Vaccinium myrtillus (myrtle blueberry), Arctostaphylos uva-ursi, Eriogonum subalpinum, Arabis spp., and various composites and grasses. Pinus contorta is more dominant on the flat plateau areas of the park than in the dissected southeast corner, but it still is the most $\aleph_{\text {nmon }}$ tree in the southeast corner (fig. 3).

Pinus contorta forests are usually found between 7,000 and 8,500 feet (McDougall and Baggley, 1956). They are best developed where annual precipitation exceeds 18-21 inches, growing season is short (60-100 days), and mean July temperature is $55^{\circ}-63^{\circ} \mathrm{F}$ (Tackle, 1961).

Pinus contorta spreads rapidly after fires (Porter, 1962; Tackle, 1961) and is commonly said to be a successional tree. Tackle believed that it is a climax species in some areas, and some of the forest in the park appear to be climax. Küchler (1964) mapped Yellowstone National Park as potentially a Pseudotsuga climax forest, but the scarcity of Pseudotsuga on the Yellowstone plateau and the relatively high precipitation and cool summers there argue for Picea-Abies as more probable potential climax species in the absence of fire. On the average, 32 fires, mostly small ones, occur in the park every year (National Park Service, unpub. data). In the northern part of the park, Houston (1973) estimated that 8-10 extensive fires have occurred in the last $300-400$ years. Judged from the abundance of charcoal in cores and in some exposures, fires have been common throughout postglacial time. Large fires occurred in 1931 (a dry year) and 1940 in the southern part of the park.

\section{PICEA-ABIES-PINUS ALBICAULIS} FOREST ASSOCIATION

The Picea-Abies-Pinus albicaulis forest occurs throughout the park above the Pinus contorta forest. In the southeastern corner of the park, this association occurs on most of the Two Ocean Plateau (fig. 6) and in the high parts of the Absaroka Range. Picea and Abies also occur in some areas along the lake, probably because in summer the lake creates a cooling effect around its margin. This forest also grows along the north-facing slopes of the Two Ocean Plateau close to the coring sites (fig. 6).

Picea engelmannii (Engelmann spruce) and Abies lasiocarpa (subalpine fir) are the dominant trees of this type. In many places Pinus albicaulis (whitebark pine) is an associate, especially at higher elevations or in dry rocky or porous soils. Pinus contorta is commonly associated with Picea and Abies below 8,500 feet, and Populus tremuloides (quaking aspen) is occasionally present. The understory commonly includes Carex geyeri (sedge), Luzula parviflora (woodrush), Juniperus communis, Vaccinium spp., Mertensia spp. (bluebell), Aconitum columbianum (monkshood), and Lupinus argenteus.

Picea-Abies-Pinus albicaulis forests occur from about 8,500 feet to treeline in the park. Treeline is about 9,200-9,800 feet in the Absaroka Range and $9,400-10,000$ feet on the Two Ocean Plateau. In the Yellowstone National Park region the Picea-AbiesPinus albicaulis forest is probably best developed where mean annual temperatures are $30^{\circ} \mathrm{F}-35^{\circ} \mathrm{F}$, mean January temperatures are $5^{\circ} \mathrm{F}-15^{\circ} \mathrm{F}$, mean July temperatures are $45^{\circ} \mathrm{F}-55^{\circ} \mathrm{F}$, and mean annual precipitation is $25-35$ inches.

\section{ALPINE ASSOCIATION}

Alpine vegetation is developed more extensively on the Beartooth Plateau, northeast of Yellowstone National Park (Porter, 1962; Johnson and Billings, 1962), but it also occurs on high areas in the park including the Absaroka Range and the Two Ocean Plateau (fig. 6).

Gramineae (Grass family), Cyperaceae (Sedge family), and Juncaceae (Rush family) are abundant in alpine areas of the park as are many other perennial herbs. In the southeast corner of the park, the most common perennial plants include Bistorta vivipara (viviparous bistort), Bistorta bistortoides (bistort), Polemonium spp. (Jacobs ladder), Potentilla spp. (cinquefoil), Salix arctica (arctic willow), Saxifraga rhomboidea (diamondleaf saxifrage), Saxifraga caespitosa (matted saxifrage), and Selaginella densa (small clubmoss).

Alpine vegetation is found from about $9,200-9,800$ feet up to the highest peaks. No climatic data are available for the alpine association in Wyoming. At the University of Colorado's alpine climatic station in the Front Range at 12,300 feet, the mean annual, mean January, and mean July temperatures were, respectively, $26^{\circ}, 7^{\circ}$, and $47^{\circ} \mathrm{F}$, some $7^{\circ}-10^{\circ} \mathrm{F}$ 
cooler than at the subalpine station at 10,000 feet for the years 1953-64 (Marr and others, 1968). Precipitation averaged about 26 inches annually at the subalpine and the alpine stations in Colorado for the years $1953-64$.

\section{LOCAL VEGETATION AROUND THE CORING SITES}

A reconnaissance map of the local vegetation was made in early September, 1966 and 1967. Four mesic to xeric communities and five semiaquatic communi- ties (herein called vegetation types) are recognized (fig. 7). Of the mesic to xeric communities, Pinus contorta forest surrounds the coring area, and PiceaAbies-Pinus albicaulis forest grows down to the base of the steep slope along the north edge of the Two Ocean Plateau (fig. 7). Grass-forb meadows grow on gentle slopes underlain by silty lake sediments, and Artemisia openings occur on south-facing steeper slopes underlain by gravel (fig. 7). The two forest types and the Artemisia openings are predominant in the regional vegetation and were discussed in the

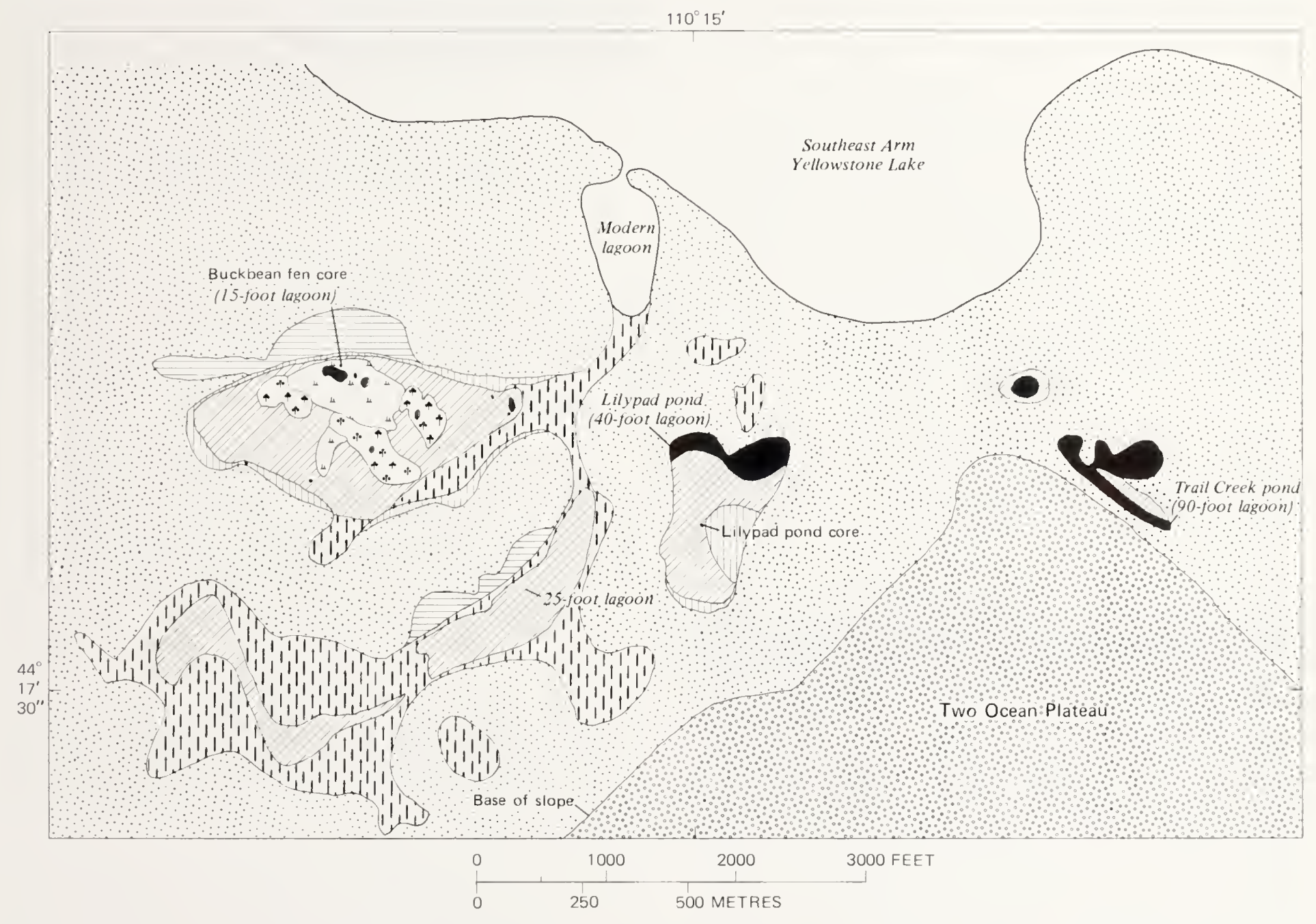

EXPLANATION

AQUATIC AND DAMP-GROUND VEGETATION (SEMIAQUATIC)

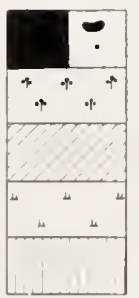

Nuphar-Potamogeton (shallow-pond aquatic) type

Menyanthes trifoliata type

Carex utriculata fen

Carex diandra-Potentilla palustris fen

Calamagrostis-Salix-Sedum rhodanthum type
UPLAND VEGETATION

(MESIC TO XERIC)

pinus contorta forest

Picea-sbies-Pinus albicauli. forest

Artemisia tridentata openings

Gramineae-forb meadows

Figure 7.- Map of local vegetation around coring sites, showing surface sample and core localities at Buckbean fen and Lilypad pond. 
preceding section. Grass-forb meadows are locally common where lake silts are present. The five semiaquatic types are discussed in the following paragraphs.

\section{NUPHAR-POTAMOGETON TYPE}

This type is the only true aquatic community. It is found in ponds on Buckbean fen and Lilypad pond (figs. 7, 8, and 9). The aquatic flora contains Nuphar luteum ssp. polysepalum (yellow pond lily), Utricularia vulgaris (common bladderwort), $U$. minor (small bladderwort), Potamogeton alpinus (northern pondweed), and Potamogeton sp. (pondweed). Only two or three of these species usually occur in any one pond.

\section{MENYANTHES TRIFOLIATA TYPE}

The Menyanthes trifoliata type occurs locally only in Buckbean fen (fig. 7) and perhaps should be included in the Nuphar-Potamogeton type. It contains mainly Menyanthes trifoliaia (buckbean) with occasional Carex utriculata (sedge). The dominant moss is Drepanocladus sp. These species grow on organic mud which was covered with a few inches of water in the fall in 1966 and 1967. The mudflats may be filled-in remnants of small ponds.

\section{CAREX UTRICULATA TYPE}

The Carex utriculata type is the most widespread of the fen communities (figs. 7, 8, and 10). Its habitat ranges from standing water to fairly dry peaty turf.
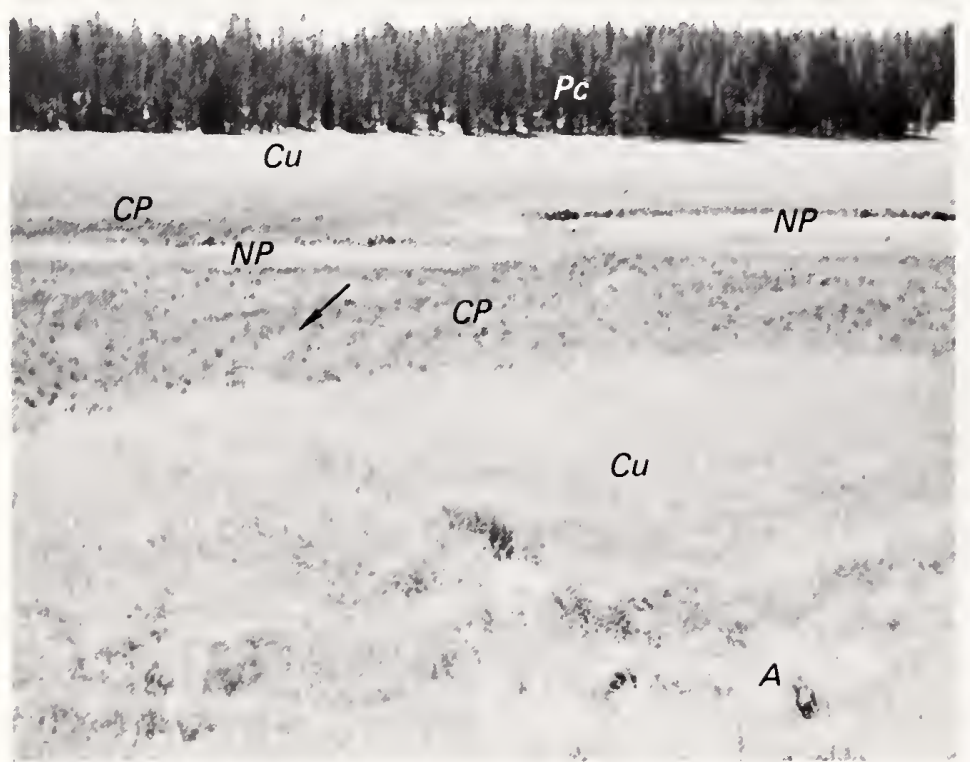

Figure 8. - Coring site (arrow) at Buckbean fen; viewed from the north. Vegetation types are Pinus contorta $(P c)$, Carex diandra - Potentilla palustris (CP), Carex utriculata $(C u)$, which is 3-4 feet high, Nuphar-Potamogeton (NP), and Artemisia (A).

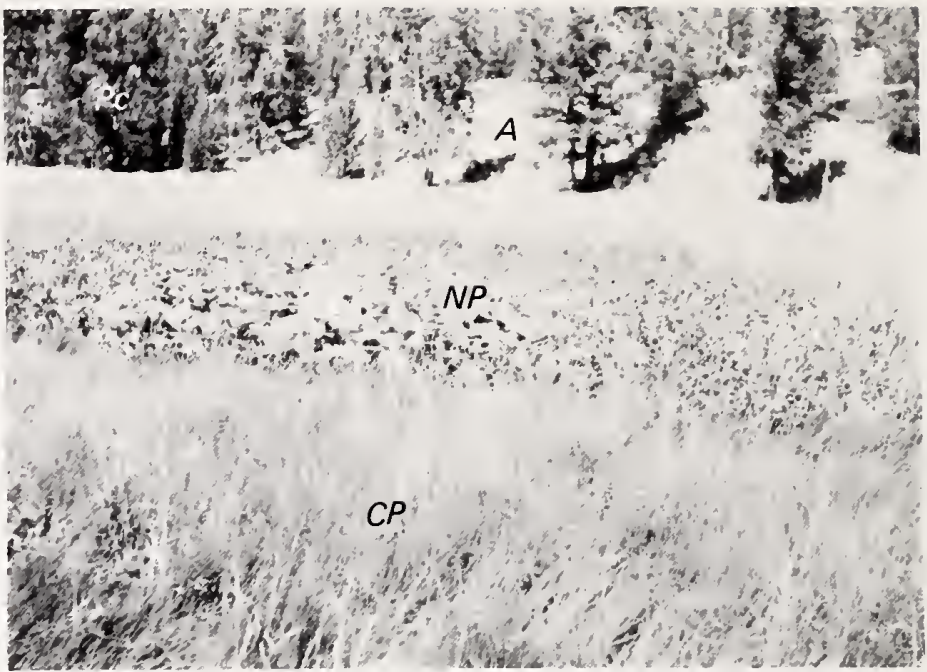

Figure 9.-Closeup of small pond shown on left in figure 8. Vegetation types are Carex diandra-Potentilla palustris ICF Nuphar-Potamogeton (NP), Artemisia (A) opening in Pinus contorta $(P c)$ forest. Sedges in foreground are about 1 foot high. View to northwest.

Carex utriculata is by far the dominant plant, with occasional Carex aquatilis, and rare Galium trifidum (small bedstraw), Salix ligulifolia, S. subcoerulea (blue willow), and Persicaria amphibia (water smartweed). The dominant moss is Drepanocladus $\mathrm{sp}$.

\section{CAREX DIANDRA-POTENTILLA PALUSTRIS TYPE}

This fen community is one of the most distinctive of the semiaquatic communities (fig. 11). It is limited to the Buckbean fen. The fen had no standing water on it in late summer, 1966 and 1967, but the roots of the plants were in water-saturated peat. The dominant plants are Carex diandra, C. limosa, C. aquatilis, Potentilla palustris (marsh cinquefoil), Eriophorum

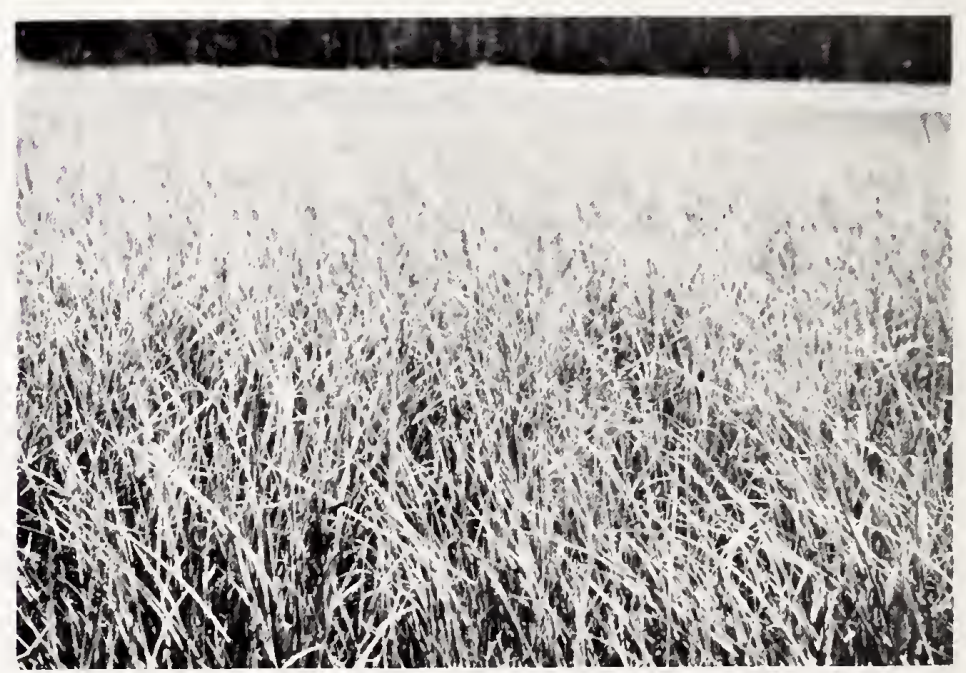

Figure 10.-Carex utriculata type. Extensive poorly drained flats underlain by peat and covered by 3 - to 4 -foot-high sedges. 


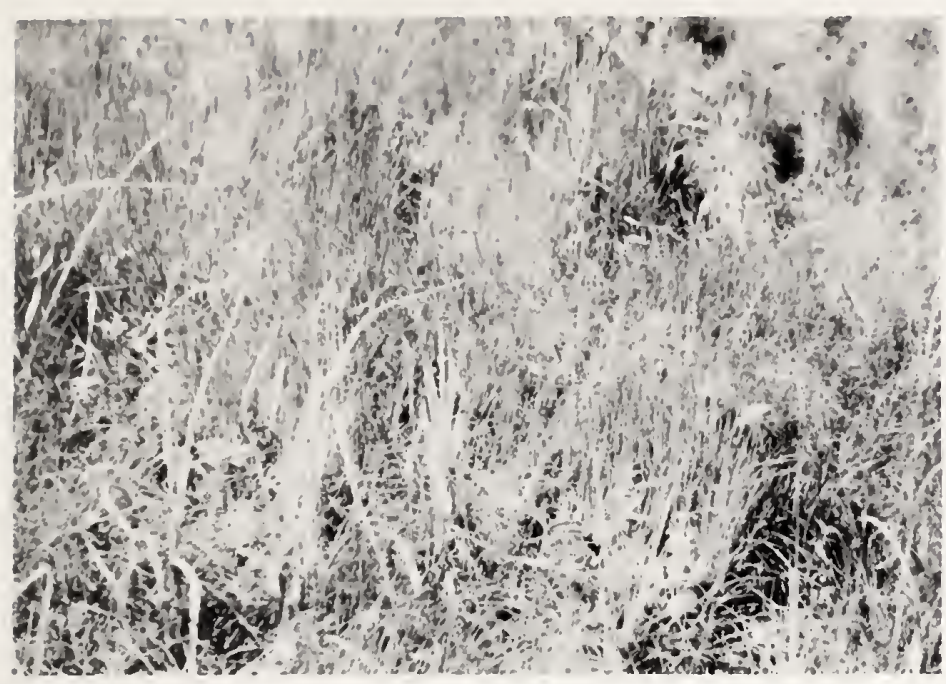

Figure 11.-Carex diandra-Potentilla palustris type. Poorly drained flats underlain by peat and covered by sedges and other forbs $0.5-2$ feet high.

sp. (cottongrass), with occasional Galium trifidum, Calamagrostis inexpansa (northern reedgrass), C. canadensis (bluejoint grass), Menyanthes trifoliata and Carex utriculata. The dominant moss is Drepanocladus sp.

\section{CALAMAGROSTIS-SALIX-SEDUM RHODANTHUM TYPE}

The community grows mainly around the margins of the depressions, though an impoverished form of this community grows on a gently sloping surface on the south part of Lilypad pond (fig. 7). This community is the richest of the semiaquatic communities. Common plants are Sedum rhodanthum (rosecrown), Pedicularis groenlandica (elephantella), Gentianopsis thermalis (Rocky Mountain fringed gentian), Anemone multifida (globose anemone), Salix subcoerulea, S. ligulifolia, Calamagrostis canadensis, C. inexpansa, Luzula parviflora, Carex canescens, and Aster spp., with occasional Pentaphylloides floribunda (shrubby cinquefoil), Bromus sp., Deschampsia caespitosa (tufted hairgrass), Luzula spicata (spike woodrush), Carex phaeocephala, and Geum macrophyllum (large-leaf avens). The dominant mosses are Climacium dendroides and in wetter places Aulacomnium palustre and Helodium blandowii. Drepanocladus sp. is less common in this community.

\section{OTHER PALEOBOTANICAL WORK IN THE AREA}

Three cores from nearby localities were recently analyzed for pollen (H. E. Wright, Jr., written commun., 1967; Waddington and Wright, 1970, 1974). One of these was taken at Cub Creek pond 12 miles west of the East Entrance to Yellowstone National
Park (SS - 26 in fig. 12), where modern vegetation is similar to that of Buckbean fen. The other cores were collected from two ponds in steppe vegetation near Cody, Wyo. Cub Creek pond pollen curves closely resemble those from Buckbean fen and suggest a similar paleoecological history. $\mathrm{A} \mathrm{C}^{14}$ - date on pine, where it shows an abrupt increase at the boundary between the two major zones, is $11,630 \pm 180$ years B.P. (sample I - 2285). The record from the two ponds near Cody dates from after Altithermal time, and the sequences are difficult to correlate with that at Buckbean fen.

Other Wyoming pollen diagrams are of cores taken from lower elevations and are dominated by steppe elements. R. C. Bright (written commun., 1967) has two unpublished diagrams from sites near Pinedale just south of the Wind River Range (fig. 12); one pollen sequence dates from late Pinedale to present time, and the other from middle Pinedale(?) to present time. Hansen (1951) reported two postglacial diagrams from the Eden Valley archeological site (fig. 12).

Bright (1966) discussed vegetation history inferred from pollen and plant macrofossil diagrams of cores from Swan Lake,west of Red Rock Pass, southeastern Idaho (fig. 12). Red Rock Pass also has a steppe vegetation at present, and the diagrams are dominated by pollen from steppe plants during postglacial time. The Swan Lake record extends back to about 12,000 years B.P.

Elsewhere in the Rocky Mountains, pollen records have been published from Glacier National Park, Mont. (Hansen, 1948); from the Front Range, Colo., (Pennak, 1963; Maher, 1972); from the San Juan Mountains, Colo. (Maher, 1963); and from the Chuska Mountains, N. Mex.(Bent and Wright, 1963; Wright and others, 1973). Bent and Wright (1963) and Maher (1963) include pollen surface samples as well as fossil-pollen diagrams.

\section{POLLEN SURFACE SAMPLES}

Pollen released by plants may be preserved in certain depositional environments. The pollen rain on any surface bears some relationship to the vegetation associations from which it is derived (Davis, 1965). If pollen rain and modern vegetation are known quantitatively, a transform function can be derived that will convert pollen percentages to numbers of plants growing in the region (Davis, 1963). If only the broad vegetational associations are known, as in Yellowstone National Park, these associations may be recognizable from their pollen rain, even though quantitative terms cannot be used. If fossil and 
modern pollen assemblages are similar, it is assumed that they were derived from similar vegetation associations. Yellowstone National Park is well suited for comparison of surface pollen assemblages with fossil pollen assemblages because of its undisturbed vegetation and simplicity of forest composition.

The relationship between the modern pollen rain and modern vegetation was examined for analogs for
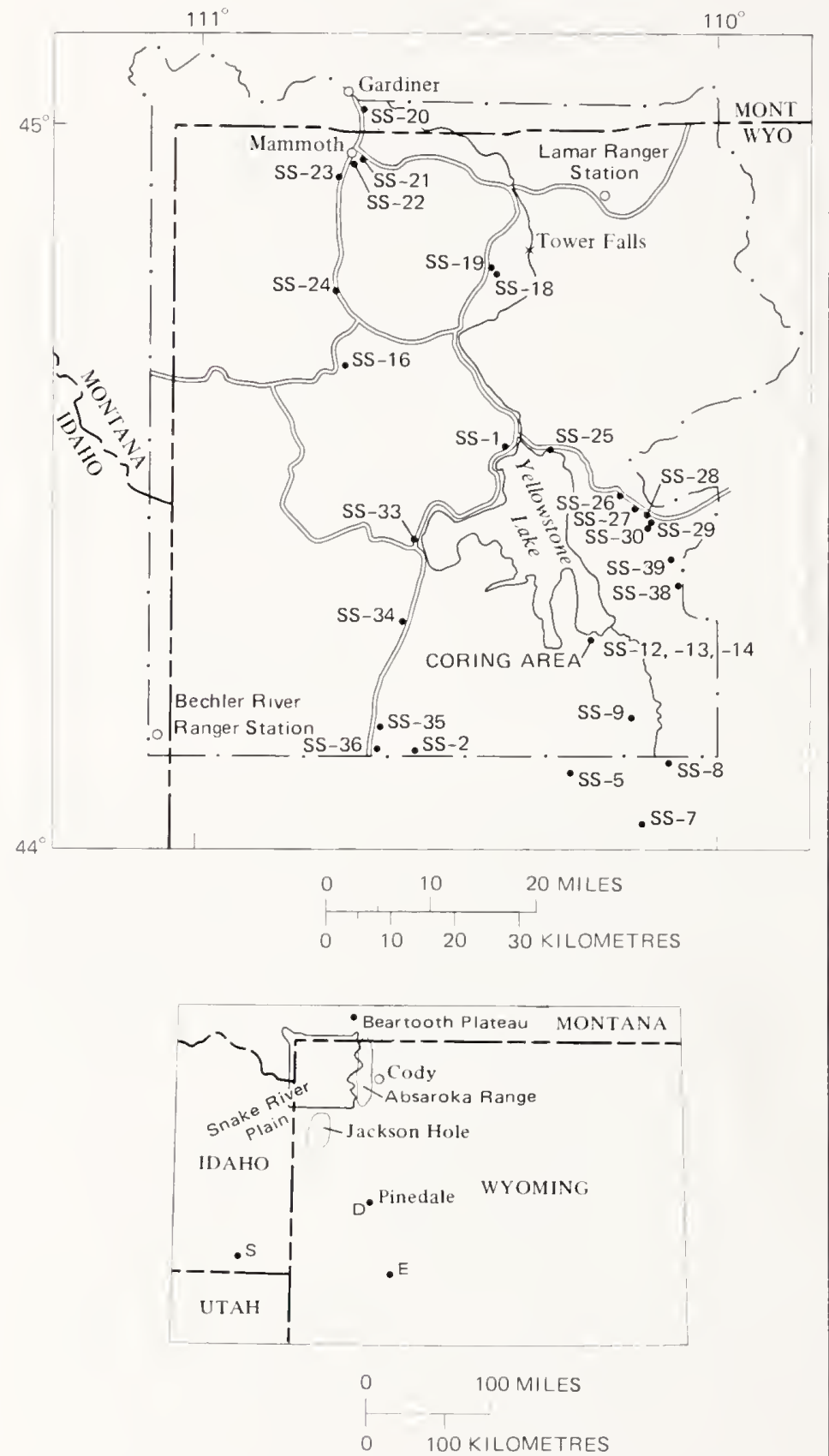

Figure 12.-Map of Yellowstone National Park, showing localities of surface samples and coring area. Surface sample SS-26 is Cub Creek pond (Waddington and Wright, 1970). SS - 12, -13, and -14 are surface samples from the coring area. Lower map shows location of other fossil pollen work: E, Eden Valley archeological site (Hansen, 1951); S, Swan Lake (Bright, 1966); D, Dew Lake (R. C. Bright, unpub. data, 1967). interpreting fossil pollen assemblages. Surface mud samples were collected for pollen analysis from ponds in the major vegetation associations of the park (fig. 12; table 2). Where pond sediments were not available moss polsters were collected. A description of the vegetation association around each surface-sample site (table 2) aids in comparing the pollen rain with the vegetation associations. The results of the surface-sample study are plotted in figure 13 .

Pollen was prepared for analysis by taking about one $\mathrm{cm}^{3}$ of sediment and adding successively $\mathrm{KOH}$, $\mathrm{HCl}, \mathrm{HF}, \mathrm{HCl}$, and acetolysis solution $(9$ parts acetic anhydride +1 part $\left.\mathrm{H}_{2} \mathrm{SO}_{4}\right)$. The preparations were mounted in silicone oil (viscosity 12,000 centistokes) for preservation and counting. Pollen percentages are based on the sum of 300 or more grains (for most samples) of total terrestrial-plant pollen (fig. 13).

\section{SURFACE SAMPLES FROM THE ARTEMISIA STEPPE}

Pollen rain in the Artemisia steppe association near the north edge of the Yellowstone plateau is fairly distinctive (fig. 13). Pinus pollen percentages are lower (45-60 percent) than almost anywhere else in the park, and Chenopodiaceae-Amaranthaceae (hereafter called Cheno-Ams) are abundant. Sarcobatus (greasewood) is nearly 20 percent in sample SS-20 and is absent in sample SS-21 (figs. 12 and 13). Artemisia pollen percentages are suprisingly low (less than 10 percent) considering that Artemisia tridentata grows abundantly at sites SS-20 and SS-21.

Maher (1963) found low Artemisia percentages at low elevations near the San Juan Mountains, Colo., and H. E. Wright, Jr. (unpub. data, 1967) found similar results in the upper levels of cores near Cody, Wyo. Bright (1966). however, found 20-60 percent Artemisia and less than 10 percent Pinus in surface samples from a steppe region in southeastern Idaho. Bright's samples were from a largely unforested area of steppe, whereas the other samples were from steppe regions bordered by large forests.

Pinus and Picea pollen in the Artemisia steppe samples probably are the same species that occur at higher elevations in the park. The few grains of Picea pollen probably represent Picea engelmannii. Picea pungens (blue spruce), a spruce of lower elevations, is not abundant in the park, and McDougall and Baggley (1956) list only one record of it. The Pinus pollen represents mainly Pinus contorta type, though no attempt was made to differentiate Pinus ponderosa, which does not occur in northwest Wyoming and adjacent areas (Critchfield and Little, 1966). Pinus contorta type pollen is distinct from that of Pinus 
TABLE 2.-Locality and description of surface samples and collection stations, Yellowstone National Park and vicinity

\begin{tabular}{|c|c|c|c|}
\hline $\begin{array}{l}\text { No. in } \\
\text { fig. } 12 \\
\text { (SS-) }\end{array}$ & $\begin{array}{l}\text { Elevation } \\
\text { (ft above } \\
\text { sea level) }\end{array}$ & Locality & Description \\
\hline
\end{tabular}

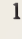

7,840

North of Lake Lodge, north edge of Yellowstone Lake.

9,140

8,660

Cub Creek pond about 1.6 miles east of Yellowstone Lake along East Entrance Road (also site of Waddington and Wright's (1970) core)

8,414 Southwest side Sylvan Lake, on East Entrance Road.

Southeast end of Eleanor Lake on East Entrance Road.

First pond on stream south of Eleanor Lake.

9,080 Highest lake south of Eleanor Lake.

7,790 Duck Lake near West Thumb.

\section{7,780 Lewis Lake}

Small artificial(?) pond between road and Lewis Canyon about 3 miles north of South Ent rance.

Pond between road and Snake River 0.2 mile north of South Entrance.

9,684 Pond 1 mile northwest of Mount Schurz, Absaroka Range.

9,640 Pond at southeast end of saddle southeast of Mount LangPond at southeast end of saddle southeast of Mount Lan
ford, Absaroka Range (pond not shown on Eagle Peak quadrangle).
Surface muds of small artificial pond. Forb meadow opening in Pinus contorta forest.

Surface muds of small pond. Carex.Gramineae meadow in PiceaA bies parkland. Pinus albicaulis in nearby areas, but none at the site.

Surface muds of small pond; pond surrounded by mosses and some Cyperaceae species, forest was mixed Pinus contorta-Picea-Abies. Moss polster from large sedge fen. Fen with Carex utriculata, $C$ spp., and Salix spp. Pinus contorta locally up to $8,300 \mathrm{ft}$, but Picea-A bies-Pinus albicaulis forest on surrounding slopes.

Surface muds: Carex fen surrounds outlet area: Pinus contorte dominates valley-bottom forest; Picea and Abies grow on higher valley slopes.

Moss polster from margin of lake; alpine vegetation with Picea A bies-Pinus albicaulis parkland on nearby slopes.

Surface muds from Carex utriculata community.

Moss polster from Calamagrostis-Salix-Sedum rhodanthum community.

Surface muds from small pond. Surface peat from the core in the Buckbean fen; Carex diandra-Potentilla palustris fen.

Surface muds of pond. Aquatics Nuphar, Potamogeton, and Callitriche in pond; narrow ring of Carex aquatilis and $C$. utruculata around pond margin; forest is pure Pinus contorta with understory of Juniperus communis.

Moss polster; tundra vegetation with Pinus albicaulis parkland just below.

Soil sample. Pinus albicautis-Picea parkland, Abies rare.

Surface muds from small (ephemeral?) pond; steppe with Sarcobatus vermiculatus, Artemisia tridentata, and abundant Bromus, Elymus, and other Gramineae.

Surface muds from pond; pond surrounded by dense growth of Scirpus cf. acutus and other sedges, grasses, and rushes: upland steppe vegetation with A rtemisia tridentata, Sarcobatus, Chrysothamnus, and numerous Gramineae.

Surface muds from pond; open Populus tremuloides-Pseudotsuga forest; Shepherdia canadensis, Ceanothus velutinus, Juniperus virginiana, and Artemisia tridentata common in open areas.

Mud from between rocks in depression; large open meadow with Carex, Gramineae. Pentaphylloides floribunda; Artemisia tridentata on higher unforested slopes below Pinus contorta tridentete

Surface muds from north end of lake; Nuphar, Myriophyllum, and Sparganium in lake; Vaccinium, Kalmia polifolia, Carex, and Gramineae along margin; Picea and Abies sparse near lake; Pinus contorta forest on upland.

Moss polster from east side of lake; a few Picea, Abies, and Pinus albicaulis near lake; Gramineae-Artemisia tridentata steppe surrounding lake; mainly Pinus contorta forest on surrounding uplands.

Surface muds from north edge of pond; large Carex utriculata fen surrounding lake; upland forest is Pinus contorta-Picea-Abrieswith occasional Pinus albicaulis.

Surface muds from shallow bay: Potamogeton alpinus and Sparganium in bay; few pond margin Carex; Picea-Abies-Pinus

albicaulis-Pinus contorta forest.
Silty surface sands. Picea-Abies-Pinus albicaulis-Pinus contorta forest.

Surface muds from northwest shore of pond; Isoetes in pond; Picea Abies-Pinus albicaulis forest. Juniperus communis and Ledum glandulosum in understory.

Surface muds from north end of lake; Vaccinium, Carex, and Phyllodoce empetriformis on shore; Picea-Abies-Pinus albicaulis forest.

Surface muds from southwest end of lake; Sparganium angustifolium, Persicario amphibia, and Isoetes in lake: Carex vesicaria and several Gramineae spp, around lake border; Piceavesicaria and several Gramineae Spp. around lake border; Picea-

Surface muds from fen on north side of lake; Carex utriculata, Persicaria amphibia, Salix sp., and Vaccinium sp. in fen: surrounded by Pinus contorta forest.

Surface muds from pond; Pinus contorta forest.

Surface muds from pond; pond aquatics are Nuphar luteum, Sparganium angustifolium, Eleocharis macrostachya, and Carex spp.; forest is Pinus contorta with reproduction of Pinus Rexilis(?). Surface muds from pond; parkland near upper edge of Picea-Abies Pinus albicaulis forest.

Surface muds from pond; Picea-A bies-Pinus albicaulis parkland. flexilis and Pinus albicaulis. (See "Pollen and Seed Identification," p. E24). The latter two species are haploxylon pines with verrucae on the distal face of the pollen grain; the former species is diploxylon and has no verrucae (Ting, 1966, p. 7). Pollen of Pinus albicaulis type includes pollen of Pinus flexilis. Ecolog. ical considerations suggest that, of these two, Pinus flexilis pollen should prevail in the Artemisia steppe 
and Pinus albicaulis pollen should dominate in higher vegetation associations, although no distinction between pollen of these pines is made here.

\section{SURFACE SAMPLE FROM PSEUDOTSUGA ASSOCIATION}

Pollen rain from one sample in an open Pseudotsuga forest cannot be distinguished from that in other forest types. Less than 1 percent Pseudotsuga pollen was found (fig. 13). Pseudotsuga is apparently a very small pollen producer; in other surface sample studies less than 5 percent Pseudotsuga pollen is usually found, even in Pseudotsuga stands (Bent and Wright, 1963; Maher, 1963; Bright, 1966). Its pollen apparently ruptures easily; the grains found in this study were commonly broken. Small fragments cannot be identified; hence, counts of Pseudotsuga may be low partly because of poor preservation. No other pollen types diagnostic of this vegetation association were found.

\section{SURFACE SAMPLES IN PINUS CONTORTA FORESTS}

Pinus pollen makes up over 80 percent of the pollen rain in Pinus contorta forests, and nonarboreal pollen is low except in large meadows (fig. 13; table 2). Pinus contorta-type pollen is usually substantially more abundant than Pinus albicaulis type. Abies and Picea pollen range from 0 to 1 percent in pure Pinus contorta stands and from 1 to 4 percent where these species grow locally in mixed forests with Pinus contorta. Diversity of pollen types is least in this vegetation association.

\section{SURFACE SAMPLES FROM \\ PICEA-ABIES-PINUS ALBICAULIS FORESTS}

Pinus pollen percentages are 80 and 85 percent, Picea is over 3.5 percent, and Abies is 1.5 percent in this forest association (fig. 13). Pinus albicaulis type pollen is several times as abundant as Pinus contorta type.

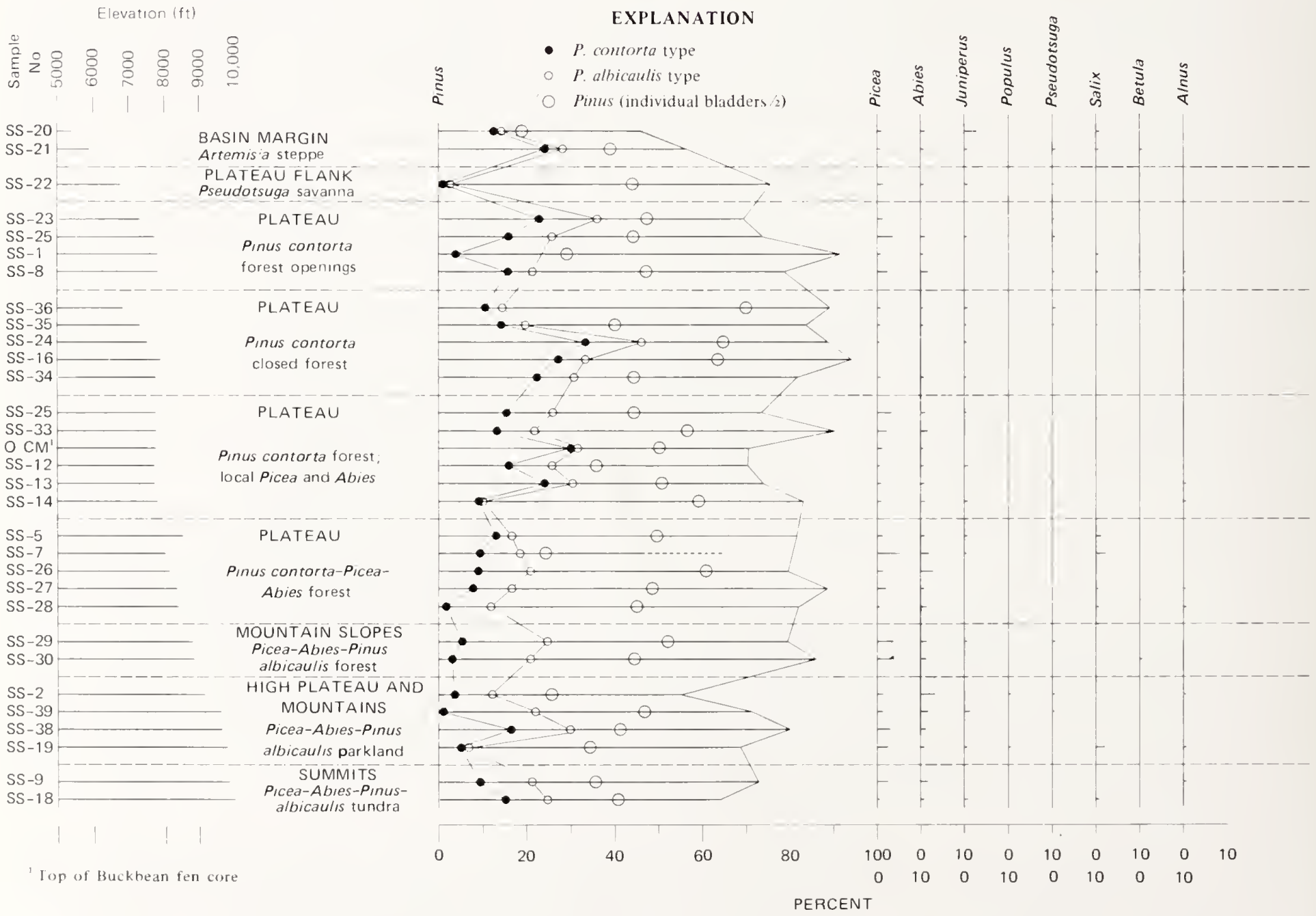

FIGURE 13. - Pollen from surface samples arranged by elevations and by vegetation types. Dashed line in sample SS - 7 shows 


\section{SURFACE SAMPLES FROM \\ PICEA-ABIES-PINUS ALBICAULIS \\ PARKLANDS AND TUNDRA}

Insufficient data are available to distinguish high-level Picea-Abies-Pinus albicaulis parklands from tundra, but together they can be distinguished from other associations by their pollen rain (figs. 13, 14). Parklands and tundra receive an average of about 70 percent Pinus pollen in Yellowstone National Park. Samples from these associations differ from those in forests by having low but consistent values of Compositae (1-3 percent) and Gramineae (4-10 percent), and they do not have the high Cheno-Ams or Sarcobatus of steppe samples. Occasional grains of plants common in alpine associations, such as Bistorta and Selaginella densa, help to define alpine and subalpine parkland pollen rain.

Maher (1963) found that in the San Juan Mountains, Colo., the Pinus pollen values are higher in alpine tundra than in Picea-Abies forests. Such is not the case in Yellowstone National Park samples. However, Pinus albicaulis is a common tree in Picea-Abies forests just below treeline in Yellowstone National Park; no ecologically analogous species is present in the San Juan Mountains. Also, my alpine sites are all from slightly above timberline. Samples from far above timberline might have higher Pinus percentages.

Artemisia pollen percentages are also higher (up to 18 percent) in subalpine and tundra areas than at lower elevations where $A$. tridentata grows (up to 7

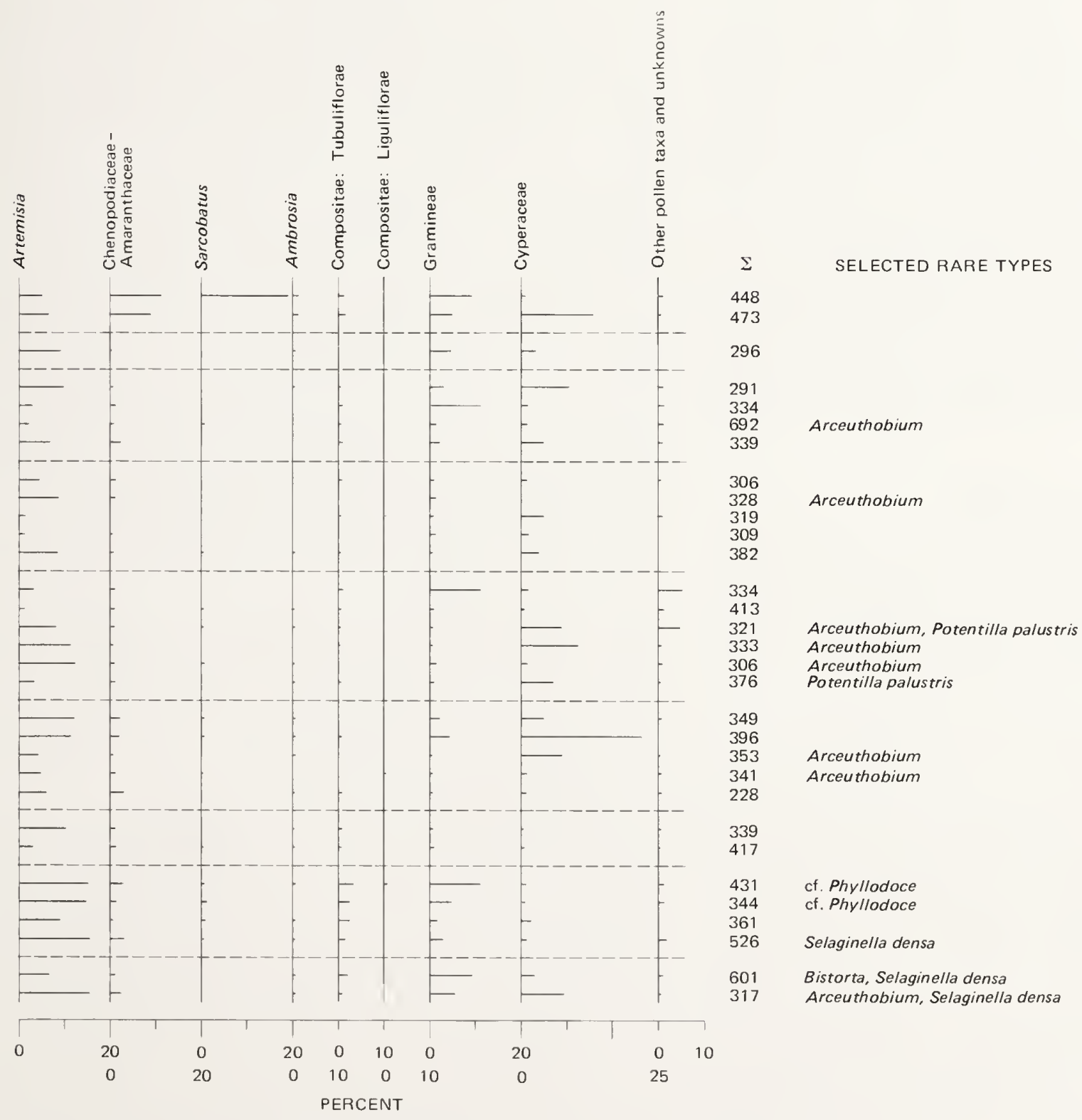

the Pinus curve with Cyperaceae excluded from the pollen sum. Pine curves are cumulative. 
percent) both in Yellowstone National Park and in the San Juan Mountains. Maher (1963) suggested that cirque lakes contain high values of Artemisia because the lakes remain frozen during the early flowering season. Pollen that falls on the ice is washed out during the melt season, and only pollen from lateflowering plants, such as Artemisia, is incorporated into the lake sediments. This process may explain the abundance of Artemisia pollen in high-elevation lakes in Yellowstone National Park.

Whether the flowering season is important or not, the source of the Artemisia pollen in alpine surface samples is still a problem. Does the pollen come from local subalpine or alpine species or does it blow in from steppe vegetation surrounding the park? The alpine species are small and produce less pollen than the larger steppe species. Pollen of other steppe species apparently were blown 10-20 miles laterally and 4,000-5,000 feet upward before deposition.

The presence of Sarcobatus and Cheno-Ams pollen in small amounts at some alpine sites (fig. 13) provides evidence that pollen from the steppe association does blow up to the tundra; these taxa grow abundantly in steppe areas but are absent from alpine areas. Compositae and Gramineae pollen in alpine sites may likewise blow up from their abundant steppe representatives, but plants in these families grow at all elevations in the park. Pinus and Picea certainly blow up from just below treeline, and in tundra areas where pollen production is low, relatively small amounts of pollen blowing in from afar could yield high pollen percentages.

\section{POLLEN RATIOS}

Ratios between two pollen types often show trends that are masked by other curves on the aggregate pollen diagram (Maher, 1963). A number of ratios were tested in the surface sample and fossil pollen diagrams, and two proved useful. Pinus albicaulis/ Pinus contorta ratios delimit Picea-Abies-Pinus albicaulis forests from other forest types (fig. 14). The dominance of Pinus contorta over such large areas in the park makes this pollen ratio low (less than 1.3) except where Pinus albicaulis grows locally. At several sites preservation of pine pollen was not good enough to identify a large proportion of the grains as to species. Even with imperfect identification, however, most pine-pollen ratios were ecologically reasonable. The assumption that the two Pinus types are preserved equally well and are representative of the entire sample seems valid.

Gramineae/Pinus ratios distinguish forested from nonforested areas (fig. 14). These ratios are high (about $0.050-0.209$ ) in the steppe and alpine vegetation associations and in large forests openings; they are low (less than 0.025) in forested areas (fig. 14; table 2).

Picea/Pinus ratios that were used successfully by Maher (1963) as an indication of subalpine vegetation show no meaningful trends in Yellowstone National Park surface samples, probably because of pollen production of Pinus albicaulis in the subalpine vegetation of the park. Lack of an ecologically analogous pine in the San Juan Mountains makes the Picea/Pinus ratio a more effective indicator of subalpine vegetation.

\section{QUATERNARY PALYNOLOGY MATERIALS AND PROCEDURES}

The cores were taken with a modified 2-inch Livingstone piston sampler (Wright and others, 1965) in early October 1966 and early September 1967. Long cores were taken from Buckbean fen and Lilypad pond (fig. 7), and shorter cores were extracted from Trail Creek pond. When core length was less than penetration, it was arbitrarily assumed for labeling purposes that the basal segment of each drive was missing. The cores were wrapped in the field in saran and heavy-duty aluminum foil, sealed with masking tape, and stored in a refrigerator. Reported here are pollen and macrofossil analyses from the 10 -m core taken in Buckbean fen and macrofossil analyses from the basal $2 \mathrm{~m}$ of the core taken in Lilypad pond. For Buckbean fen, pollen samples were taken at about $10-\mathrm{cm}$ (centimetres) intervals in the basal $2 \mathrm{~m}$ and at about $20-\mathrm{cm}$ intervals in the remainder of the core. These samples received the same chemical treatment as the surface samples.

Plant macrofossils were prepared by soaking a 50 - $\mathrm{ml}$ (millilitre) sample of sediment for as long as 2 days in very weak (less than 5 percent) $\mathrm{KOH}$. The sample was then washed through 32- and 140-mesh $(0.5$ and $1.0 \mathrm{~mm})$ screens with a shower nozzle. Macrofossils were picked from the washed samples with a small brush and stored in glycerin.

The pollen was identified by comparison with the reference collection at the U.S. Geological Survey, Denver, Colo. The collection is large but is incomplete for Rocky Mountain species. Macrofossils were identified by comparison with the seed collection at the University of Colorado Herbarium. The collection is small and is fairly complete only for taxa encountered as fossils.

The certainty of identification of pollen and macrofossils is indicated by the use of "type" and "cf." 


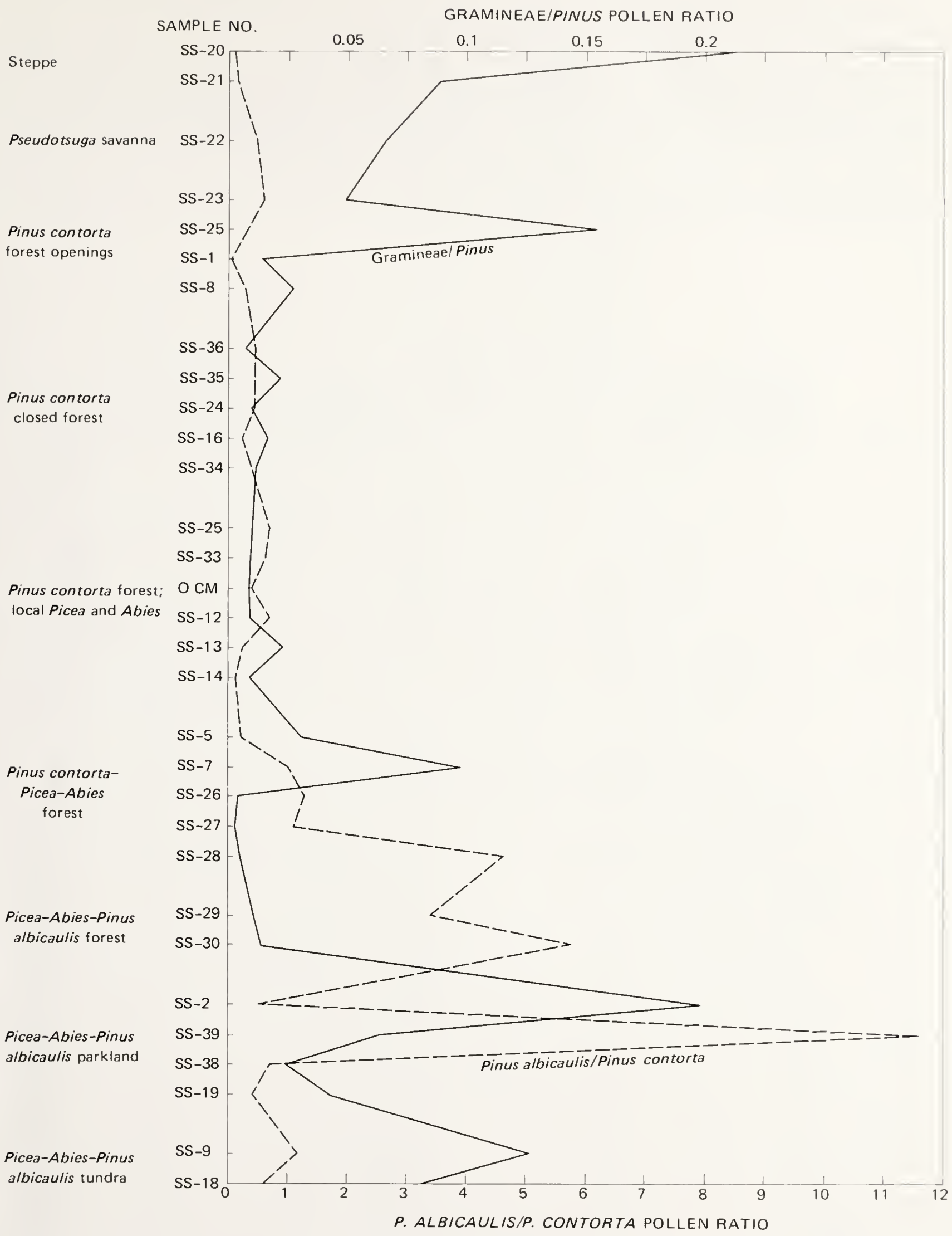

FIGURE 14.-Ratios for surface pollen samples. 
If the name of a taxon is followed by "type," the specimen matches not only that taxon but also others, and the name is selected for ecological or geographical reasons. The use of "cf." (=confere) means that identification is uncertain because of poor preservation, inadequate reference materials, or ill-defined morphology (Watts and Winter, 1966).

Relative pollen frequencies were determined with few exceptions from counts of at least 300 grains/slide. The slides used in this study are stored in the University of Colorado Museum. Percentage curves in the pollen diagram (fig. 15) are based on a pollen sum of total pollen excluding spores and aquatic-plant pollen.

The Pinus pollen curve is a cumulative plot of four curves (fig. 15). Pinus albicaulis type is plotted at the base of the total pine curve. Above that curve is plotted Pinus contorta type. The next higher curve compresses individual bladders (treated as half grains) of Pinus pollen (times $1 / 2$, that is, two half pines are counted as one pine); the top curve comprises whole Pinus grains that could not be differentiated as to

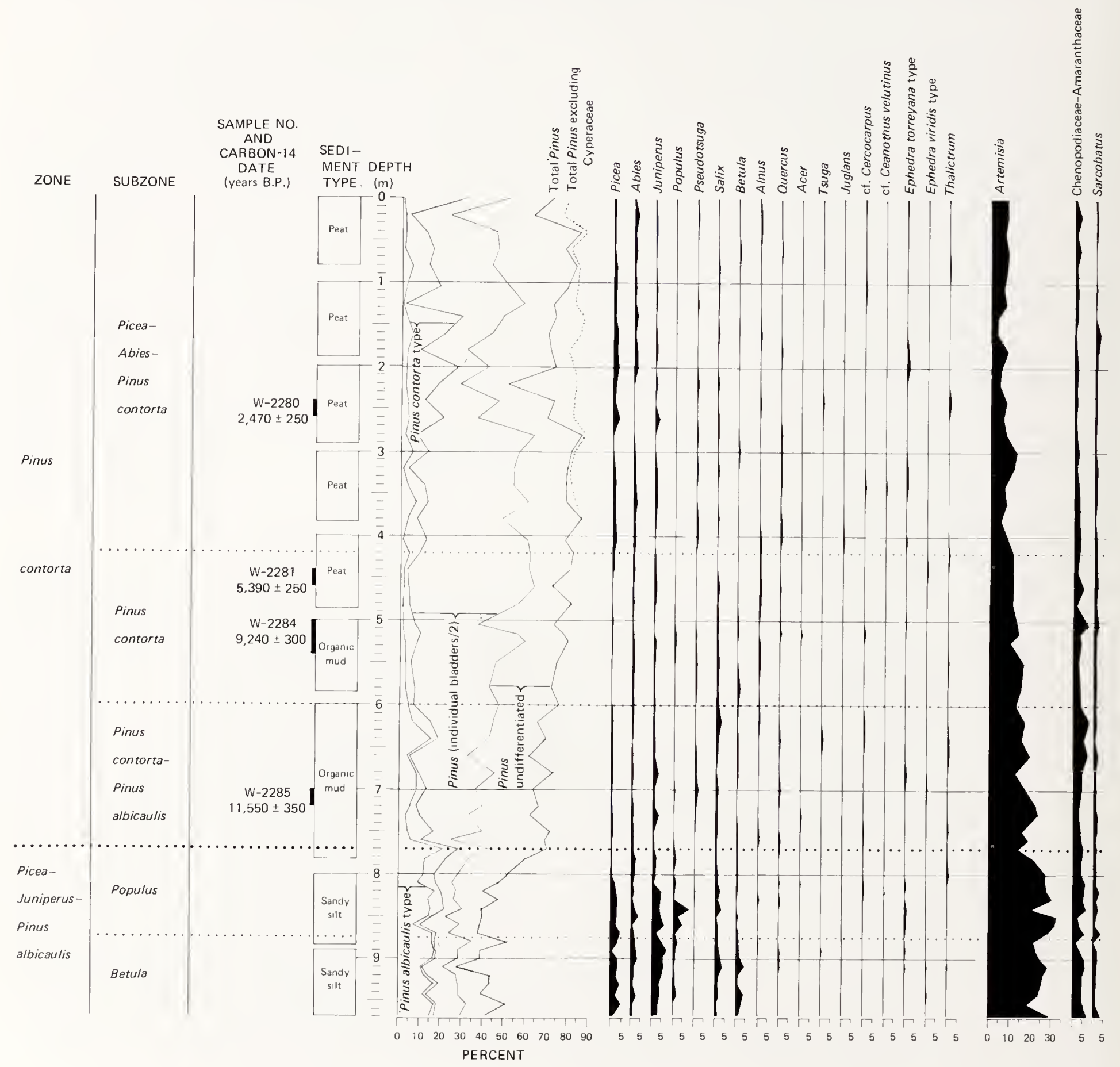

Figure 15.- 
species. A separate total Pinus pollen curve is plotted for the upper $400 \mathrm{~cm}$ of the core. This curve excludes Cyperaceae pollen from the pollen sum because of its local origin.

The pollen diagram (fig. 15) is divided into two pollen assemblage zones (hereafter simply called zones). The zones are biostratigraphic units called assemblage zones as defined by the American
Commission on Stratigraphic Nomenclature (1961). The zones are defined by their fossil content and position in the core. The name of each zone carries implications about the ecological conditions at the time of deposition. Similar zones appear in the core from Cub Creek pond (Waddington and Wright, 1970) and other cores (R. G. Baker, unpub. data). This regional similarity of zones implies that vegetation changes

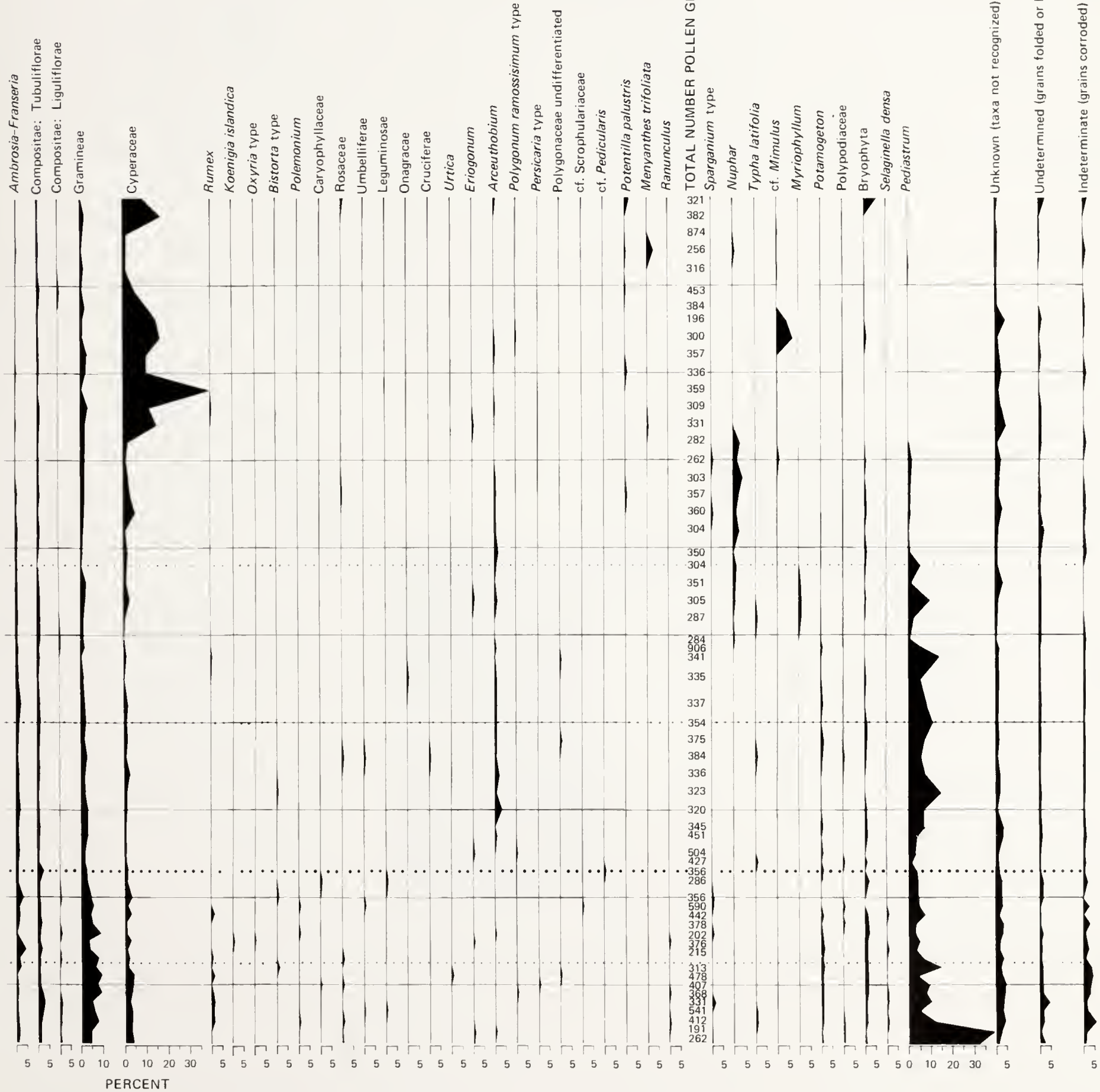

Pollen from Buckbean fen core. 
were similar throughout the region. The zonation of the diagram is summarized in table 3 , and the pollen counts for Buckbean fen are listed in table 4.

The time and stratigraphic relationship between the assemblage zones, the $\mathrm{C}^{14}$ dates, and the glacial periods is shown in figure 16 .

\section{POLLEN AND SEED IDENTIFICATION}

Pollen and spores were identified using the reference collection of the U.S. Geological Survey, Denver, Colo. Plant macrofossils were identified by comparison with a collection that I assembled from the University of Colorado Herbarium. On plates $5-10$, the COLO numbers are the University of Colorado Herbarium numbers of voucher specimens for reference seeds, needles, and bracts. RGB numbers are my own collection. Some of the criteria for identification are discussed here so that the pollen and macrofossil taxa can be better evaluated.

\section{SELAGINELLACEAE}

Trilete spores in the lower part of the Buckbean fen core match Selaginella densa perfectly (pl. 1), and this is the only species reported in the modern park flora (McDougall and Baggley, 1956). It is most common above timberline. Two other species occur in eastern Wyoming (Porter, 1962). Another species, S. selaginoides, occurs at middle elevations in western Wyoming, but its spores can be distinguished from those of $S$. densa on morphologic grounds.

\section{PINACEAE}

A few grains were found that match Pseudotsuga menziesii (pl. 1). Larix occidentalis Nutt. and Larix lyallii Parl. have similar but smaller grains, and these trees now grow from central Idaho westward (Bright, 1966). Pseudotsuga grows locally in Yellowstone National Park. I have, therefore, identified the pollen as Pseudotsuga. One needle of Pseudotsuga was found (pl. 5).

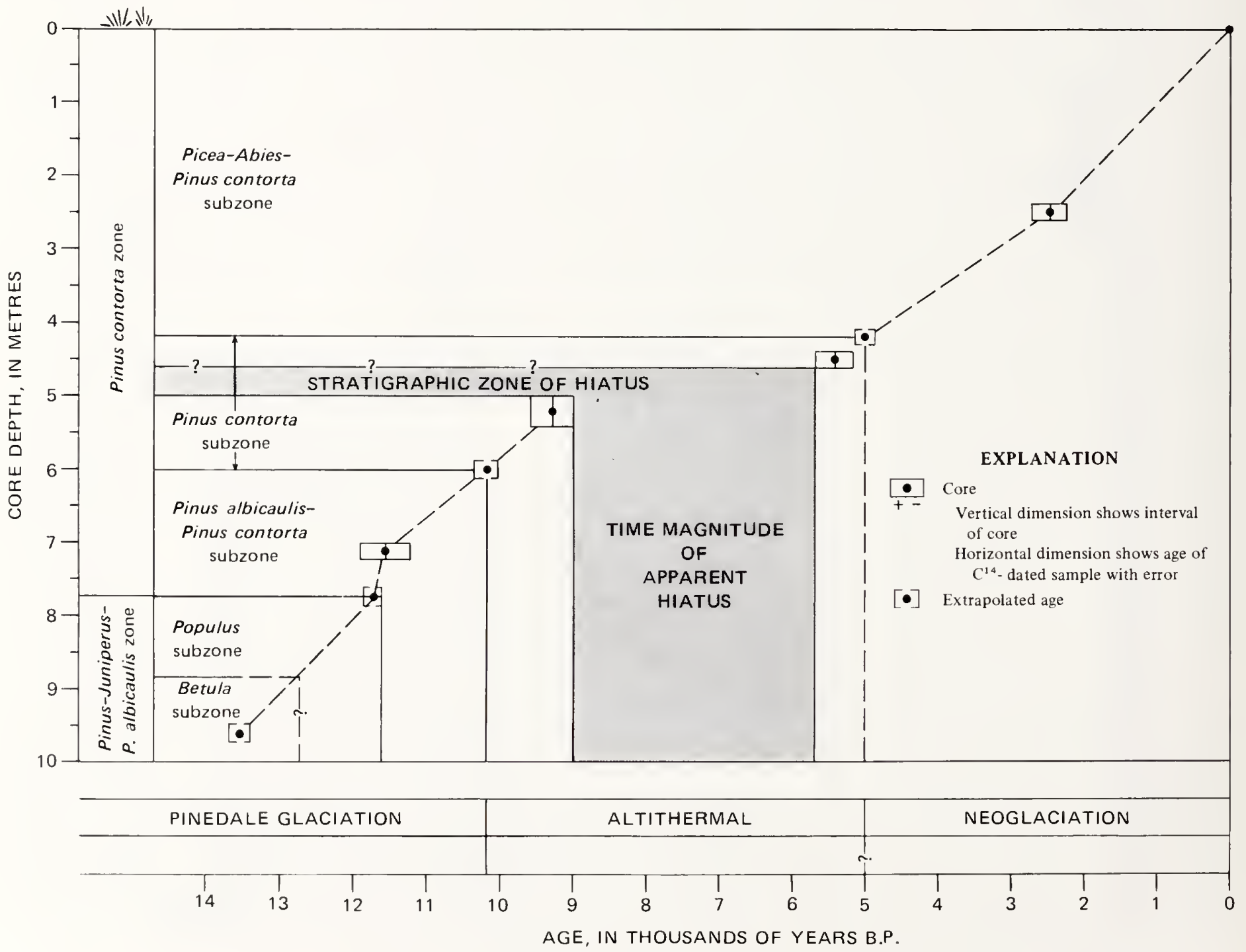

FIGURE 16.-Relationships between assemblage zones, carbon-14 and extrapolated ages, and time-stratigraphic boundaries. 


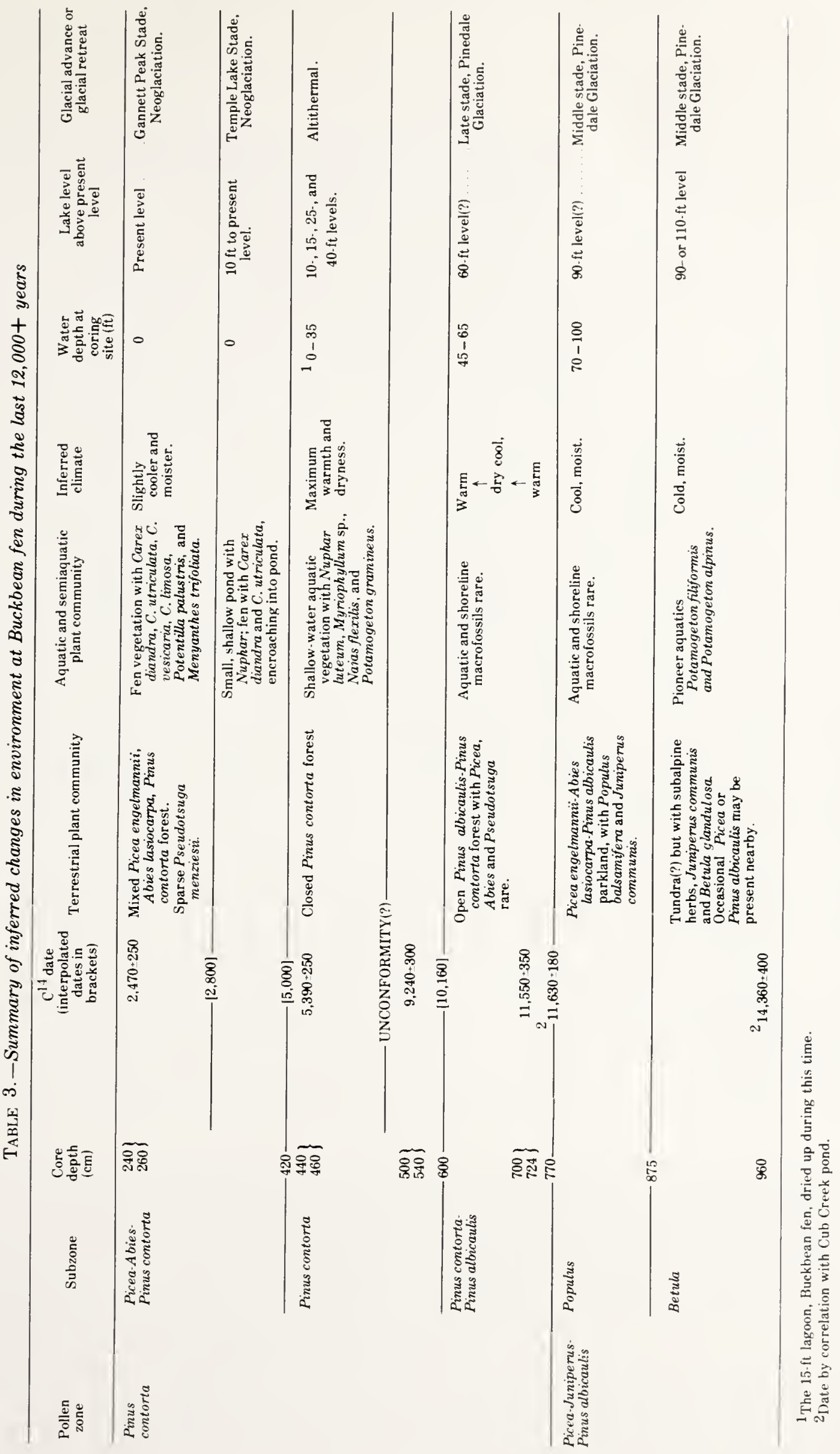




\begin{tabular}{|c|c|c|c|c|c|c|c|c|c|c|c|c|c|c|c|c|c|c|c|c|c|c|c|}
\hline 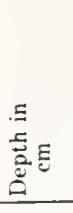 & 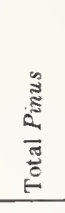 & 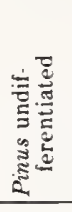 & 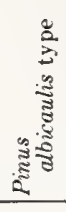 & 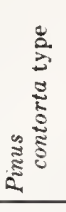 & $\begin{array}{l}\tilde{u} \\
\text { s. } \\
\end{array}$ & 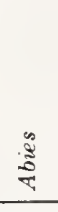 & 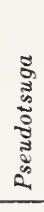 & 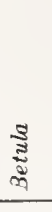 & $\frac{\tilde{3}}{\tilde{3}}$ & 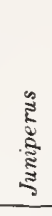 & $\begin{array}{l}\frac{3}{3} \\
\frac{3}{2} \\
2\end{array}$ & $\begin{array}{l}\text { 胥 } \\
\text { 永 }\end{array}$ & है & ב气 & 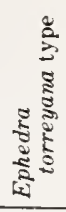 & 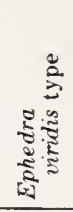 & 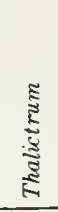 & 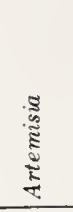 & 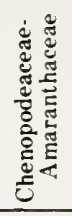 & 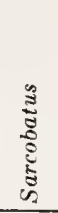 & 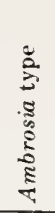 & 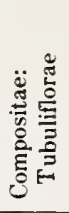 & 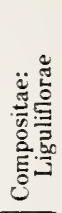 \\
\hline $\begin{array}{r}0 \\
20 \\
40 \\
60 \\
80 \\
105 \\
125 \\
140 \\
160 \\
180 \\
200 \\
220 \\
240 \\
260 \\
260 \\
300 \\
320 \\
340 \\
3460 \\
380 \\
405 \\
420\end{array}$ & $\begin{array}{l}230 \\
241 \\
748 \\
200 \\
262 \\
357 \\
278 \\
143 \\
211 \\
253 \\
246 \\
181 \\
223 \\
228 \\
241 \\
211 \\
238 \\
280 \\
231 \\
260 \\
272 \\
249\end{array}$ & $\begin{array}{l}129 \\
223 \\
644 \\
161 \\
221 \\
2275 \\
272 \\
86 \\
147 \\
223 \\
155 \\
118 \\
187 \\
152 \\
219 \\
176 \\
227 \\
243 \\
195 \\
237 \\
229 \\
221\end{array}$ & $\begin{array}{r}4 \\
8 \\
19 \\
4 \\
16 \\
10 \\
2 \\
5 \\
17 \\
10 \\
8 \\
8 \\
10 \\
12 \\
6 \\
15 \\
3 \\
10 \\
20 \\
10 \\
3 \\
12\end{array}$ & $\begin{array}{c}97 \\
10 \\
85 \\
35 \\
25 \\
72 \\
4 \\
52 \\
47 \\
20 \\
83 \\
55 \\
26 \\
64 \\
16 \\
20 \\
88 \\
27 \\
16 \\
13 \\
40 \\
16\end{array}$ & $\begin{array}{r}5 \\
3 \\
5 \\
2 \\
6 \\
8 \\
6 \\
2 \\
7 \\
7 \\
8 \\
5 \\
2 \\
10 \\
1 \\
0 \\
3 \\
6 \\
4 \\
5 \\
7 \\
2\end{array}$ & $\begin{array}{l}1 \\
8 \\
6 \\
4 \\
1 \\
1 \\
5 \\
2 \\
3 \\
2 \\
6 \\
6 \\
6 \\
0 \\
0 \\
0 \\
1 \\
2 \\
4 \\
5 \\
2 \\
3 \\
2\end{array}$ & $\begin{array}{l}0 \\
3 \\
0 \\
0 \\
0 \\
0 \\
1 \\
0 \\
0 \\
0 \\
0 \\
2 \\
0 \\
0 \\
0 \\
0\end{array}$ & $\begin{array}{l}0 \\
0 \\
0 \\
3 \\
0 \\
0 \\
0 \\
0 \\
0 \\
0 \\
0 \\
0 \\
0 \\
0 \\
0 \\
1 \\
0 \\
0 \\
0 \\
0 \\
0 \\
0\end{array}$ & $\begin{array}{l}0 \\
0 \\
0 \\
0 \\
2 \\
1 \\
1 \\
0 \\
1 \\
0 \\
0 \\
1 \\
0 \\
1 \\
1 \\
0 \\
1 \\
0 \\
0 \\
1 \\
0 \\
0\end{array}$ & $\begin{array}{l}0 \\
1 \\
4 \\
0 \\
0 \\
1 \\
1 \\
0 \\
1 \\
2 \\
0 \\
2 \\
0 \\
7 \\
0 \\
0 \\
2 \\
4 \\
3 \\
1 \\
1\end{array}$ & $\begin{array}{l}0 \\
0 \\
0 \\
0 \\
0 \\
0 \\
0 \\
0 \\
0 \\
0 \\
0 \\
0 \\
0 \\
0 \\
0 \\
0 \\
0 \\
0 \\
0 \\
0 \\
0 \\
0\end{array}$ & $\begin{array}{l}1 \\
0 \\
0 \\
2 \\
0 \\
0 \\
0 \\
0 \\
0 \\
1 \\
0 \\
0 \\
0 \\
0 \\
2 \\
1 \\
1 \\
2 \\
0 \\
1 \\
2 \\
0\end{array}$ & $\begin{array}{l}0 \\
1 \\
1 \\
0 \\
0 \\
1 \\
0 \\
0 \\
1 \\
0 \\
0 \\
0 \\
1 \\
0 \\
0 \\
0 \\
0 \\
0 \\
0\end{array}$ & $\begin{array}{l}2 \\
0 \\
0 \\
0 \\
0 \\
1 \\
0 \\
0 \\
0 \\
0 \\
0 \\
0 \\
0 \\
0 \\
0 \\
0 \\
0 \\
1 \\
0 \\
0 \\
0 \\
0\end{array}$ & $\begin{array}{l}2 \\
0 \\
0 \\
0 \\
0 \\
0 \\
0 \\
0 \\
0 \\
2 \\
0 \\
0 \\
0 \\
0 \\
0 \\
0 \\
0 \\
0 \\
0 \\
0 \\
0\end{array}$ & $\begin{array}{l}0 \\
0 \\
0 \\
0 \\
0 \\
0 \\
0 \\
0 \\
0 \\
4 \\
0 \\
0 \\
0 \\
0 \\
0 \\
1 \\
0 \\
1 \\
0\end{array}$ & $\begin{array}{l}0 \\
0 \\
0 \\
0 \\
1 \\
0 \\
0 \\
0 \\
0 \\
0 \\
0 \\
0 \\
1 \\
0 \\
0 \\
0 \\
0 \\
0 \\
0 \\
0 \\
1\end{array}$ & $\begin{array}{l}28 \\
31 \\
62 \\
22 \\
26 \\
30 \\
30 \\
7 \\
11 \\
29 \\
17 \\
16 \\
24 \\
21 \\
22 \\
33 \\
33 \\
23 \\
22 \\
15 \\
30 \\
33\end{array}$ & $\begin{array}{r}3 \\
13 \\
10 \\
7 \\
5 \\
9 \\
7 \\
3 \\
2 \\
2 \\
4 \\
5 \\
4 \\
3 \\
2 \\
3 \\
6 \\
3 \\
9 \\
7 \\
8 \\
11 \\
7\end{array}$ & $\begin{array}{l}1 \\
3 \\
6 \\
0 \\
0 \\
1 \\
1 \\
0 \\
6 \\
2 \\
2 \\
2 \\
1 \\
1 \\
1 \\
0 \\
0 \\
3 \\
1 \\
2 \\
0 \\
2 \\
2\end{array}$ & $\begin{array}{l}1 \\
2 \\
0 \\
1 \\
1 \\
0 \\
0 \\
0 \\
1 \\
0 \\
1 \\
1 \\
0 \\
1 \\
0 \\
0 \\
0 \\
0 \\
0 \\
2 \\
1 \\
2\end{array}$ & $\begin{array}{l}1 \\
1 \\
4 \\
2 \\
1 \\
8 \\
4 \\
1 \\
2 \\
3 \\
4 \\
2 \\
5 \\
3 \\
1 \\
2 \\
2 \\
4 \\
1 \\
2 \\
0\end{array}$ & $\begin{array}{l}0 \\
0 \\
0 \\
0 \\
0 \\
1 \\
0 \\
0 \\
0 \\
0 \\
0 \\
0 \\
0 \\
0 \\
0 \\
0 \\
0 \\
0 \\
0 \\
0 \\
0 \\
0\end{array}$ \\
\hline $\begin{array}{l}440 \\
460 \\
480 \\
505 \\
515 \\
525 \\
550 \\
580 \\
600\end{array}$ & $\begin{array}{l}282 \\
220 \\
235 \\
208 \\
697 \\
271 \\
248 \\
241 \\
265\end{array}$ & $\begin{array}{l}271 \\
209 \\
224 \\
188 \\
610 \\
244 \\
231 \\
217 \\
243\end{array}$ & $\begin{array}{r}5 \\
4 \\
2 \\
3 \\
13 \\
8 \\
9 \\
9 \\
14\end{array}$ & $\begin{array}{r}6 \\
7 \\
9 \\
17 \\
74 \\
19 \\
8 \\
15 \\
8\end{array}$ & $\begin{array}{l}2 \\
0 \\
0 \\
1 \\
1 \\
1 \\
0 \\
0 \\
0\end{array}$ & $\begin{array}{l}3 \\
1 \\
1 \\
0 \\
2 \\
2 \\
2 \\
1 \\
2\end{array}$ & $\begin{array}{l}1 \\
0 \\
0 \\
0 \\
1 \\
0 \\
2\end{array}$ & $\begin{array}{l}0 \\
0 \\
0 \\
1 \\
1 \\
0 \\
0 \\
4 \\
1\end{array}$ & $\begin{array}{l}0 \\
3 \\
1 \\
2 \\
2 \\
2 \\
3 \\
2 \\
3 \\
3\end{array}$ & $\begin{array}{l}1 \\
4 \\
1 \\
0 \\
0 \\
3 \\
2 \\
1 \\
4\end{array}$ & $\begin{array}{l}0 \\
0 \\
0 \\
0 \\
1 \\
1 \\
0 \\
0 \\
0\end{array}$ & $\begin{array}{l}0 \\
1 \\
0 \\
0 \\
3 \\
0 \\
0 \\
0 \\
0\end{array}$ & $\begin{array}{l}1 \\
3 \\
1 \\
0 \\
0\end{array}$ & $\begin{array}{l}0 \\
0 \\
0 \\
0 \\
2 \\
0 \\
0 \\
0 \\
0\end{array}$ & $\begin{array}{l}1 \\
0 \\
0 \\
0 \\
0 \\
0 \\
0 \\
0 \\
0\end{array}$ & $\begin{array}{l}0 \\
0 \\
0 \\
1 \\
0 \\
0 \\
0 \\
0 \\
0\end{array}$ & $\begin{array}{l}0 \\
0 \\
0 \\
0 \\
0 \\
0 \\
1 \\
0 \\
0\end{array}$ & $\begin{array}{r}38 \\
34 \\
31 \\
37 \\
126 \\
34 \\
54 \\
50 \\
43\end{array}$ & $\begin{array}{r}6 \\
14 \\
4 \\
21 \\
29 \\
12 \\
9 \\
11 \\
10\end{array}$ & $\begin{array}{l}2 \\
4 \\
3 \\
5 \\
7 \\
3 \\
4 \\
4 \\
3\end{array}$ & $\begin{array}{l}1 \\
1 \\
2 \\
1 \\
8 \\
2 \\
3 \\
8 \\
\mathbf{5}\end{array}$ & $\begin{array}{l}2 \\
3 \\
3 \\
4 \\
5 \\
2 \\
1 \\
2 \\
5\end{array}$ & $\begin{array}{l}0 \\
0 \\
0 \\
0 \\
1 \\
0 \\
0 \\
0 \\
0\end{array}$ \\
\hline $\begin{array}{l}620 \\
640 \\
660 \\
680 \\
700 \\
720 \\
730 \\
750 \\
760 \\
770\end{array}$ & $\begin{array}{l}243 \\
266 \\
207 \\
236 \\
203 \\
227 \\
277 \\
361 \\
294 \\
249\end{array}$ & $\begin{array}{l}188 \\
195 \\
192 \\
208 \\
163 \\
200 \\
234 \\
282 \\
250 \\
150\end{array}$ & $\begin{array}{l}26 \\
58 \\
12 \\
25 \\
27 \\
17 \\
13 \\
20 \\
24 \\
76\end{array}$ & $\begin{array}{r}29 \\
13 \\
3 \\
3 \\
13 \\
10 \\
30 \\
59 \\
20 \\
23\end{array}$ & $\begin{array}{l}3 \\
2 \\
2 \\
3 \\
1 \\
0 \\
3 \\
6 \\
1 \\
1\end{array}$ & $\begin{array}{l}1 \\
0 \\
1 \\
1 \\
0 \\
2 \\
2 \\
4 \\
3 \\
3 \\
3\end{array}$ & $\begin{array}{l}0 \\
0 \\
1 \\
1 \\
5 \\
2 \\
1 \\
0\end{array}$ & $\begin{array}{l}0 \\
1 \\
1 \\
2 \\
1 \\
0 \\
0 \\
2 \\
2 \\
0\end{array}$ & $\begin{array}{l}8 \\
4 \\
2 \\
0 \\
3 \\
3 \\
5 \\
4 \\
2 \\
0\end{array}$ & $\begin{array}{r}2 \\
4 \\
3 \\
10 \\
2 \\
4 \\
12 \\
2 \\
2 \\
2\end{array}$ & $\begin{array}{l}0 \\
0 \\
0 \\
0 \\
1 \\
0 \\
0 \\
0 \\
2 \\
2\end{array}$ & $\begin{array}{l}0 \\
1 \\
0 \\
0 \\
1 \\
0 \\
0 \\
0 \\
2 \\
2\end{array}$ & $\begin{array}{l}1 \\
0 \\
0 \\
0 \\
0\end{array}$ & $\begin{array}{l}2 \\
1 \\
0 \\
0 \\
0 \\
0 \\
0 \\
1 \\
0 \\
0\end{array}$ & $\begin{array}{l}0 \\
0 \\
0 \\
1 \\
0 \\
0 \\
0 \\
0 \\
0 \\
0\end{array}$ & $\begin{array}{l}0 \\
0 \\
0 \\
0 \\
0 \\
0 \\
0 \\
0 \\
0 \\
0\end{array}$ & $\begin{array}{l}0 \\
1 \\
1 \\
0 \\
0\end{array}$ & $\begin{array}{r}63 \\
59 \\
65 \\
39 \\
56 \\
76 \\
105 \\
78 \\
70 \\
48\end{array}$ & $\begin{array}{l}27 \\
19 \\
22 \\
12 \\
13 \\
10 \\
14 \\
17 \\
17 \\
17\end{array}$ & $\begin{array}{l}4 \\
1 \\
6 \\
3 \\
4 \\
3 \\
8 \\
6 \\
2 \\
5\end{array}$ & $\begin{array}{l}5 \\
3 \\
3 \\
3 \\
6 \\
3 \\
3 \\
5 \\
6 \\
4 \\
0\end{array}$ & $\begin{array}{l}4 \\
2 \\
3 \\
1 \\
2 \\
5 \\
4 \\
1 \\
3 \\
8\end{array}$ & $\begin{array}{l}0 \\
0 \\
0 \\
0 \\
0 \\
0 \\
0 \\
0 \\
0 \\
0\end{array}$ \\
\hline $\begin{array}{l}782 \\
801 \\
810 \\
820 \\
830 \\
842 \\
850 \\
860 \\
870 \\
880 \\
890 \\
900 \\
910 \\
920 \\
930 \\
943 \\
953 \\
958\end{array}$ & $\begin{array}{r}172 \\
1182 \\
279 \\
175 \\
179 \\
79 \\
149 \\
83 \\
136 \\
167 \\
186 \\
157 \\
101 \\
144 \\
233 \\
160 \\
98 \\
109\end{array}$ & $\begin{array}{r}107 \\
121 \\
172 \\
86 \\
99 \\
34 \\
89 \\
61 \\
71 \\
113 \\
101 \\
86 \\
60 \\
98 \\
129 \\
108 \\
64 \\
67\end{array}$ & $\begin{array}{l}34 \\
42 \\
58 \\
75 \\
53 \\
30 \\
53 \\
14 \\
59 \\
51 \\
82 \\
65 \\
38 \\
39 \\
87 \\
47 \\
32 \\
38\end{array}$ & $\begin{array}{r}31 \\
19 \\
49 \\
14 \\
27 \\
15 \\
7 \\
8 \\
6 \\
3 \\
3 \\
6 \\
3 \\
7 \\
17 \\
5 \\
2 \\
4\end{array}$ & $\begin{array}{r}1 \\
3 \\
13 \\
12 \\
14 \\
7 \\
11 \\
6 \\
17 \\
11 \\
5 \\
16 \\
14 \\
10 \\
24 \\
11 \\
10 \\
5\end{array}$ & $\begin{array}{r}6 \\
5 \\
5 \\
7 \\
3 \\
4 \\
414 \\
1 \\
6 \\
6 \\
11 \\
12 \\
4 \\
5 \\
5 \\
10 \\
2 \\
3\end{array}$ & $\begin{array}{l}0 \\
0 \\
0 \\
2 \\
1 \\
0 \\
0 \\
0 \\
0 \\
0 \\
0 \\
0 \\
0 \\
0 \\
0 \\
0 \\
0 \\
0\end{array}$ & $\begin{array}{r}1 \\
0 \\
4 \\
2 \\
0 \\
0 \\
2 \\
0 \\
5 \\
3 \\
6 \\
6 \\
14 \\
3 \\
3 \\
15 \\
4 \\
2\end{array}$ & $\begin{array}{r}1 \\
4 \\
7 \\
9 \\
6 \\
6 \\
2 \\
3 \\
6 \\
5 \\
9 \\
10 \\
13 \\
5 \\
9 \\
7\end{array}$ & $\begin{array}{r}6 \\
6 \\
1 \\
19 \\
0 \\
7 \\
16 \\
13 \\
7 \\
15\end{array}$ & $\begin{array}{r}5 \\
0 \\
10 \\
5 \\
1 \\
16 \\
8 \\
9 \\
3 \\
4 \\
5 \\
4 \\
1 \\
3 \\
4 \\
9 \\
0 \\
0\end{array}$ & $\begin{array}{l}0 \\
0 \\
3 \\
0 \\
3 \\
0 \\
0 \\
0 \\
0 \\
0 \\
1 \\
1 \\
0 \\
0 \\
0 \\
0 \\
0 \\
1\end{array}$ & $\begin{array}{l}0 \\
0 \\
2 \\
0 \\
2 \\
0 \\
1 \\
1 \\
0 \\
2 \\
1 \\
0 \\
2 \\
1 \\
3 \\
0 \\
0 \\
0\end{array}$ & $\begin{array}{l}0 \\
0 \\
0 \\
0 \\
0 \\
0 \\
0 \\
0 \\
0 \\
0 \\
0 \\
0 \\
0 \\
0 \\
0 \\
0 \\
0 \\
0\end{array}$ & $\begin{array}{l}0 \\
0 \\
0 \\
0 \\
0 \\
0 \\
0 \\
0 \\
0 \\
0 \\
1 \\
0 \\
1 \\
0 \\
0 \\
0 \\
0 \\
0\end{array}$ & $\begin{array}{l}0 \\
0 \\
1 \\
0 \\
0 \\
1 \\
0 \\
1 \\
0 \\
0 \\
0 \\
0 \\
1 \\
0 \\
1 \\
0 \\
0\end{array}$ & $\begin{array}{l}0 \\
3 \\
0 \\
1 \\
0 \\
0 \\
0 \\
0 \\
0 \\
0 \\
0 \\
0 \\
1 \\
0 \\
0 \\
0 \\
0 \\
0\end{array}$ & $\begin{array}{r}61 \\
97 \\
911 \\
122 \\
113 \\
41 \\
121 \\
67 \\
102 \\
69 \\
106 \\
97 \\
103 \\
85 \\
135 \\
97 \\
36 \\
75\end{array}$ & $\begin{array}{r}12 \\
15 \\
35 \\
26 \\
18 \\
13 \\
9 \\
7 \\
20 \\
5 \\
18 \\
23 \\
21 \\
16 \\
24 \\
18 \\
9 \\
18\end{array}$ & $\begin{array}{r}3 \\
6 \\
6 \\
11 \\
6 \\
4 \\
4 \\
1 \\
13 \\
0 \\
9 \\
8 \\
7 \\
5 \\
7 \\
3 \\
2 \\
9\end{array}$ & $\begin{array}{r}2 \\
10 \\
8 \\
8 \\
4 \\
0 \\
7 \\
9 \\
5 \\
7 \\
1 \\
2 \\
4 \\
1 \\
2 \\
4 \\
3 \\
3\end{array}$ & $\begin{array}{r}4 \\
3 \\
9 \\
4 \\
7 \\
2 \\
5 \\
4 \\
4 \\
3 \\
6 \\
5 \\
9 \\
10 \\
14 \\
6 \\
3 \\
4\end{array}$ & $\begin{array}{l}0 \\
1 \\
0 \\
0 \\
0 \\
1 \\
0 \\
0 \\
1 \\
0 \\
0 \\
0 \\
0 \\
2 \\
2 \\
2 \\
0 \\
1\end{array}$ \\
\hline
\end{tabular}

Juniperus pollen is common at the bottom of the core (pl. 1). Species of Juniperus cannot be distinguished by their pollen, but needles and a twig of Juniperus communis are identified from two levels (pl. 5). Juniperus communis is the only juniper that grows from low elevations below the plateau up to and above timberline. Juniperus virginiana L. var. scopulorum Lemmon grows only at low elevations around Mammoth and in other areas. I believe most of the Juniperus pollen to be Juniperus communis.

Picea pollen (pl. 1) was not differentiated as to species, but Picea engelmannii is the only spruce that grows abundantly on the plateau. The only fir that grows in the park is Abies lasiocarpa. Needles of Picea engelmanii have been identified (pl. 5). Probably all the spruce and fir pollen belongs to these two species.

Pine pollen (pl. 1) was grouped into haploxylon (with distal verrucae) and diploxylon (without distal verrucae) (Ting, 1966). Two haploxylon pines, Pinus flexilis and Pinus albicaulis, occur in the park (McDougall and Baggley, 1956). Pinus flexilis grows only at low elevations around the margins of the plateau. Pinus albicaulis grows mostly up near timberline but also on rocky cliffs and ledges at lower 


\begin{tabular}{|c|c|c|c|c|c|c|c|c|c|c|c|c|c|c|c|c|c|c|c|c|c|}
\hline 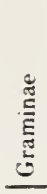 & 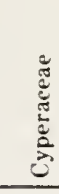 & 气્气 & $\frac{5}{5}$ & 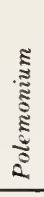 & 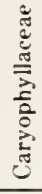 & 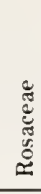 & 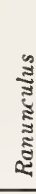 & 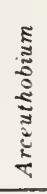 & 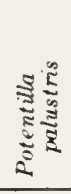 & & 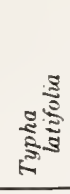 & 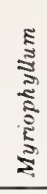 & 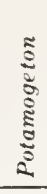 & 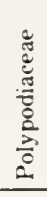 & 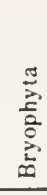 & 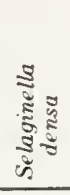 & 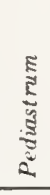 & 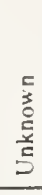 & 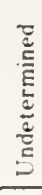 & 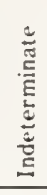 & 营 \\
\hline 2 & 29 & 0 & 0 & 0 & 0 & 2 & 0 & 4 & 7 & 2 & 0 & 0 & 0 & 2 & 20 & 0 & 1 & 5 & 9 & 7 & 0 \\
\hline 9 & 66 & 0 & 0 & 0 & 0 & 0 & 0 & 0 & 0 & 0 & 1 & 0 & 0 & 0 & 0 & 0 & 0 & 1 & 2 & 1 & 0 \\
\hline 12 & 15 & 0 & 0 & 0 & 0 & 0 & 0 & 0 & 1 & 1 & 0 & 0 & 0 & 0 & 0 & 0 & 0 & 14 & 1 & 0 & 0 \\
\hline 2 & 3 & 0 & 0 & 0 & 0 & 0 & 0 & 0 & 1 & 2 & 0 & 0 & 0 & 0 & 0 & 0 & 0 & 2 & 1 & 3 & Menyanthes 7 . \\
\hline 7 & 4 & 0 & 0 & 0 & 0 & 0 & 0 & 0 & 0 & 0 & 0 & 0 & 0 & 0 & 0 & 0 & 2 & 4 & 0 & 1 & 0 \\
\hline 5 & 24 & 0 & 0 & 0 & 0 & 0 & 0 & 0 & 1 & 0 & 1 & 0 & 0 & 1 & 0 & 0 & 0 & 3 & 0 & 0 & Caprifoliaceae 1, Equisetum 1. \\
\hline 8 & 45 & 0 & 0 & 0 & 0 & 0 & 0 & 0 & 0 & 0 & 0 & 0 & 0 & 0 & 1 & 0 & 0 & 4 & 1 & 1 & 0 \\
\hline 2 & 30 & 0 & 0 & 0 & 0 & 0 & 0 & 0 & 0 & 0 & 0 & 0 & 0 & 1 & 0 & 0 & 0 & 18 & 2 & 1 & 0 \\
\hline 3 & 50 & 0 & 0 & 0 & 0 & 0 & 0 & 1 & 0 & 0 & 0 & 0 & 0 & 0 & 4 & 0 & 0 & 25 & 0 & 0 & Polygonum ramosissimum type 1 . \\
\hline 10 & 37 & 0 & 0 & 0 & 0 & 0 & 0 & 1 & 0 & 1 & 0 & 0 & 0 & 0 & 0 & 0 & 0 & 7 & 1 & 0 & 0 \\
\hline 8 & 34 & 0 & 0 & 0 & 0 & 0 & 0 & 0 & 1 & 0 & 0 & 0 & 0 & 0 & 0 & 0 & 0 & 9 & 2 & 5 & 0 \\
\hline 2 & 142 & 0 & 0 & 0 & 0 & 0 & 0 & 0 & 0 & 0 & 0 & 0 & 0 & 0 & 0 & 0 & 0 & 5 & 0 & 1 & 0 \\
\hline 10 & 36 & 1 & 0 & 0 & 0 & 0 & 0 & 1 & 0 & 0 & 0 & 0 & 0 & 0 & 0 & 0 & 0 & 7 & 3 & 0 & Tsuga 1. \\
\hline 5 & 50 & 0 & 0 & 0 & 0 & 0 & 0 & 0 & 0 & 0 & 0 & 0 & 0 & 1 & 0 & 0 & 0 & 16 & 3 & 0 & Eriogonum 1, Menyanthes 1 . \\
\hline 5 & 5 & 0 & 0 & 0 & 0 & 0 & 0 & 0 & 0 & 7 & 0 & 0 & 0 & 0 & 0 & 0 & 0 & 1 & 2 & 3 & 0 \\
\hline 4 & 3 & 0 & 0 & 0 & 0 & 0 & 0 & 0 & 0 & 4 & 0 & 0 & 0 & 0 & 1 & 0 & 4 & 7 & 0 & 0 & 0 \\
\hline 5 & 6 & 0 & 0 & 0 & 0 & 0 & 0 & 1 & 0 & 12 & 0 & 0 & 0 & 0 & 0 & 0 & 3 & 5 & 0 & 0 & 0 \\
\hline 6 & 9 & 0 & 0 & 0 & 0 & 0 & 0 & 2 & 2 & 8 & 0 & 0 & 0 & 0 & 1 & 0 & 3 & 5 & 3 & 2 & cf. Ceanothus velutinus 1 . \\
\hline 5 & 14 & 0 & 0 & 0 & 0 & 0 & 0 & 1 & 0 & 4 & 0 & 0 & 0 & 0 & 2 & 0 & 2 & 9 & 0 & 1 & Sparganium 1. \\
\hline 3 & 1 & 0 & 0 & 0 & 0 & 0 & 0 & 1 & 0 & 7 & 0 & 0 & 0 & 0 & 0 & 0 & 0 & 4 & 6 & 0 & 0 \\
\hline 2 & 6 & 0 & 0 & 0 & 0 & 0 & 0 & 6 & 0 & 0 & 0 & 0 & 0 & 0 & 2 & 0 & 2 & 2 & 5 & 2 & Juglans 1. \\
\hline 0 & 3 & 0 & 0 & 0 & 0 & 0 & 0 & 1 & 0 & 3 & 0 & 0 & 0 & 0 & 1 & 0 & 16 & 2 & 0 & 0 & 0 \\
\hline 8 & 3 & 0 & 0 & 0 & 0 & 0 & 0 & 0 & 0 & 2 & 0 & 1 & 0 & 0 & 0 & 0 & 3 & 11 & 1 & 0 & 0 \\
\hline 6 & 7 & 0 & 0 & 0 & 0 & 0 & 0 & 3 & 0 & 1 & 0 & 2 & 0 & 0 & 1 & 0 & 30 & 2 & 2 & 0 & Eriogonum 1. \\
\hline 3 & 2 & 0 & 0 & 0 & 0 & 0 & 0 & 0 & 0 & 0 & 1 & 2 & 0 & 0 & 0 & 0 & 6 & 3 & 1 & 0 & 0 \\
\hline 3 & 0 & 0 & 0 & 0 & 0 & 0 & 0 & 0 & 0 & 1 & 0 & 0 & 0 & 0 & 0 & 0 & 2 & 0 & 2 & 4 & 0 \\
\hline 14 & 3 & 0 & 0 & 0 & 0 & 0 & 0 & 2 & 0 & 0 & 0 & 0 & 1 & 0 & 0 & 0 & 54 & 15 & 0 & 3 & 0 \\
\hline $\begin{array}{r}17 \\
0\end{array}$ & 4 & 1 & 0 & 0 & 0 & 0 & 0 & 0 & 0 & 0 & 0 & 0 & 0 & 1 & 0 & 0 & 50 & 3 & 0 & 1 & 0 \\
\hline 3 & 0 & 0 & 0 & 0 & 0 & 0 & 0 & 1 & 0 & 0 & 0 & 0 & 0 & 0 & 1 & 0 & 18 & 4 & 0 & 1 & Onagraceae 1. \\
\hline 5 & 5 & 0 & 0 & 0 & 0 & 0 & 0 & 2 & 0 & 0 & 0 & 0 & 1 & 0 & 0 & 0 & 29 & 3 & 1 & 3 & 0 \\
\hline 7 & 4 & 0 & 0 & 0 & 0 & 0 & 0 & 1 & 0 & 0 & 0 & 1 & 0 & 0 & 3 & 0 & 39 & 3 & 0 & 0 & 0 \\
\hline 4 & 7 & 0 & 0 & 0 & 0 & 0 & 0 & 2 & 0 & 0 & 0 & 0 & 3 & 0 & 3 & 0 & 26 & 5 & 1 & 1 & Polygonum 1. \\
\hline 10 & 2 & 0 & 0 & 0 & 0 & 2 & 0 & 1 & 0 & 0 & 1 & 0 & 1 & 1 & 1 & 0 & 21 & 2 & 0 & 1 & Cruciferae 1 , Umbelliferae 1. \\
\hline 6 & 7 & 0 & 0 & 0 & 0 & 0 & 0 & 6 & 0 & 0 & 0 & 0 & 0 & 0 & 0 & 0 & 25 & 6 & 0 & 1 & \\
\hline 6 & 3 & 0 & 1 & 0 & 0 & 0 & 0 & 1 & 0 & 0 & 0 & 0 & 0 & 0 & 0 & 0 & 47 & 6 & 1 & 1 & 0 \\
\hline 10 & 3 & 0 & 0 & 0 & 0 & 0 & 0 & 8 & 0 & 0 & 0 & 0 & 0 & 0 & 1 & 0 & 21 & 1 & 0 & 0 & 0 \\
\hline 10 & 1 & 0 & 0 & 0 & 0 & 0 & 0 & 0 & 0 & 0 & 0 & 0 & 1 & 0 & 0 & 0 & 23 & 10 & 2 & 2 & 0 \\
\hline 13 & 2 & 0 & 0 & 0 & 0 & 0 & 0 & 1 & 0 & 0 & 0 & 0 & 0 & 0 & 4 & 0 & 16 & 12 & 2 & 5 & Acer ne gundo 1. \\
\hline 9 & 1 & 0 & 0 & 0 & 0 & 0 & 0 & 0 & 0 & 0 & 0 & 0 & 1 & 0 & 0 & 0 & 13 & 6 & 0 & 0 & Polygonum ramosissimum 1 Eriogonum 1. \\
\hline 8 & 4 & 0 & 0 & 0 & 0 & 0 & 0 & 0 & 0 & 0 & 2 & 0 & 0 & 1 & 1 & 0 & 4 & 3 & 0 & 2 & \\
\hline 9 & 6 & 0 & 0 & 0 & 0 & 0 & 0 & 0 & 0 & 0 & 0 & 0 & 1 & 0 & 0 & 0 & 11 & 5 & 0 & 0 & cf. Pedicularis 2. \\
\hline 8 & 3 & 0 & 0 & 0 & 1 & 0 & 0 & 0 & 0 & 0 & 0 & 0 & 0 & 0 & 4 & 0 & 11 & 7 & 3 & 3 & Leguminosae 1, Equisetum 1. \\
\hline 11 & 8 & 0 & 1 & 0 & 0 & 0 & 0 & 0 & 0 & 0 & 0 & 0 & 0 & 0 & 0 & 0 & 15 & 7 & 3 & 0 & \\
\hline 32 & 7 & 0 & 0 & 1 & 3 & 0 & 0 & 0 & 0 & 0 & 0 & 0 & 0 & 1 & 0 & 0 & 21 & 0 & 15 & 14 & Sparganium 1, Acer 3, cf. Scrophulariaceae 1 \\
\hline 17 & 14 & 5 & 0 & 0 & 0 & 0 & 0 & 0 & 0 & 0 & 0 & 0 & 3 & 0 & 4 & 2 & 34 & 4 & 0 & 0 & Fraxinus 1 . \\
\hline 19 & $\underset{2}{14}$ & 0 & 0 & 0 & 0 & 0 & 0 & 0 & 0 & 0 & 0 & 0 & 0 & 1 & 0 & 0 & 13 & 11 & 0 & 10 & 0 \\
\hline 18 & 1 & 0 & 0 & 1 & 0 & 0 & 0 & 1 & 0 & 0 & 0 & 0 & 0 & 0 & 3 & 0 & 6 & 5 & 2 & 1 & 0 \\
\hline 12 & 11 & 0 & 0 & 0 & 0 & 0 & 1 & 0 & 0 & 0 & 0 & 0 & 2 & 0 & 4 & 0 & 17 & 6 & 2 & 5 & Eriogonum 1, Oxyria 1, Koenigia 1. \\
\hline 8 & 2 & 0 & 0 & 0 & 0 & 0 & 0 & 0 & 0 & 0 & 0 & 0 & 2 & 0 & 2 & 1 & 7 & 3 & 2 & 4 & 0 \\
\hline 29 & 8 & 2 & 0 & 0 & 0 & 2 & 0 & 0 & 0 & 0 & 0 & 0 & 1 & 0 & 4 & 0 & 23 & 12 & 1 & 2 & 0 \\
\hline 20 & 3 & 0 & 0 & 0 & 0 & 0 & 0 & 0 & 0 & 0 & 0 & 0 & 3 & 0 & 3 & 1 & 47 & 7 & 2 & 11 & Erigonum 3. \\
\hline 45 & 19 & 7 & 0 & 0 & 0 & 0 & 0 & 0 & 0 & 0 & 0 & 0 & 1 & 0 & 8 & 0 & 21 & 13 & 3 & 18 & Urtica 3, Eriogonum 3. \\
\hline 28 & 15 & 0 & 1 & 0 & 1 & 1 & 0 & 0 & 0 & 0 & 0 & 0 & 0 & 0 & 4 & 0 & 37 & 17 & 5 & 11 & Polygonum persicaria 1. \\
\hline 34 & 12 & 2 & 0 & 0 & 0 & 0 & 1 & 0 & 0 & 0 & 0 & 0 & 1 & 0 & 5 & 1 & 29 & 14 & 6 & 9 & Polygonum ramosissimum type 1 , Plantago 1 \\
\hline 15 & 7 & 4 & 0 & 0 & 0 & 0 & 0 & 0 & 0 & 0 & 0 & 0 & 0 & 0 & 1 & 1 & 32 & 13 & 0 & 3 & Sparganium 4. \\
\hline 31 & 19 & 5 & 0 & 0 & 0 & 0 & 0 & 0 & 0 & 0 & 1 & 0 & 1 & 0 & 1 & 2 & 29 & 15 & 9 & 10 & Umbelliferae 1, Leguminosae 1. \\
\hline 31 & 12 & 6 & 0 & 1 & 0 & 2 & 1 & 0 & 0 & 0 & 1 & 0 & 1 & 2 & 3 & 3 & 51 & 17 & 6 & 21 & 0 \\
\hline 9 & 6 & 0 & 0 & 0 & 0 & 0 & 0 & 1 & 0 & 0 & 0 & 0 & 0 & 1 & 0 & 0 & 75 & 5 & 0 & 3 & Eriogonum 1. \\
\hline 11 & 10 & 0 & 0 & 0 & 0 & 1 & 0 & 0 & 0 & 0 & 0 & 0 & 1 & 1 & 2 & 0 & 85 & 4 & 5 & 2 & 0 \\
\hline
\end{tabular}

elevations on the plateau. Haploxylon pine needles are fairly common in the cores (pl. 5), but no morphological criteria have been found to distinguish Pinus flexilis from Pinus albicaulis needles. In fact, the living trees are distinguished only by difference in cone length. Considering present distribution, the pollen and needles are referred to Pinus albicaulis type, and they almost certainly represent this species.

The only diploxylon pine that grows in or near the park is Pinus contorta. Pinus ponderosa is absent from northwest Wyoming. Needles are identified with certainty as Pinus contorta (pl. 5).
A few grains of Tsuga were found in the core (pl. 1). Both T. mertensiana and T. heterophylla are represented. A Tsuga grain also was found in the surface samples, and all grains are attributed to long-distance transport. Both species have mainly a west coast distribution, though both extend inland to northern Idaho.

\section{BETULACEAE}

Betula pollen grains are most abundant near the bottom of the Picea-Abies-Pinus albicaulis zone in Buckbean fen. They are even more abundant in this zone at Cub Creek pond (Waddington and Wright, 
1974). No Betula macrofossils were found in Buckbean fen core, but in the equivalent zone of the Lilypad pond core Betula glandulosa seeds and catkin scales are common (pl. 6). Betula occidentalis, the only other birch that occurs in northwestern Wyoming, is found at lower elevations. The pollen of the birch peak, therefore, is attributed to $B$. glandulosa.

Alnus pollen, which occurs sparsely but continuously in the Pinus contorta subzone of the Pinus contorta zone, probably represents Alnus tenuifolia. It is the only species that occurs in Wyoming today, and one fruit of Alnus tenuifolia was found (pl. 6). The fruits are wingless and cannot be confused with other species of western alder or birch.

\section{COMPOSITAE}

A single Compositae seed was found in the Lilypad pond core. It may be identifiable to species, but the reference collection for the large family has not been completed. Compositae pollen was separated into Ambrosia type (pl. 2), Artemisia, subfamily Tubuliflorae, and subfamily Liguliflorae (pl. 2). Ambrosia type probably includes pollen of Franseria, a western plant of semiarid regions.

\section{CRASSULACEAE}

The Sedum seed is referred to $S$. rhodanthum. $S$. rosea has similar seeds, but a delicate epidermal reticulum and black tip seem to be absent on seeds of S. rosea. S. rhodanthum now grows on the margins of the fen surface.

\section{CRUCIFERAE}

Seeds of Rorippa occur in both Lilypad pond and Buckbean fen (pl. 10). They match $R$. islandica but cannot be distinguished on the basis of our reference material from other Rocky Mountain Rorippa species.

One seed of Descurainia californica was found in the Lilypad pond (pl. 8). This species has broader seeds with coarser surface reticulum than other species in this area. It is a montane to subalpine species in Colorado (Harrington, 1954).

\section{HALORAGACEAE}

Four-pored Myriophyllum pollen occurs at the same level as the single seed in Buckbean fen (pl. 2). The seed cannot be assigned to a species, but Myriophyllum spicatum ssp. exalbescens and $M$. verticillatum are the only two species that grow in the park today (McDougall and Baggley, 1956). Seeds of Myriophyllum occur abundantly in cores from nearby sites.

\section{LORANTHACEAE}

No attempt was made to identify Arceuthobium pollen to species because of insufficient reference material (pl. 2). Three species occur in northwest Wyoming: A. douglasii infects Pseudotsuga as its principal host, $A$. campylopodum is parasitic mainly on Pinus ponderosa, and $A$. americanum is parasitic on Pinus contorta (Hawksworth and Wiens, 1972). Because the fossil pollen occurs mainly in the Pinus contorta zone, the most likely species is Arceuthobium americanum.

\section{MENYANTHACEAE}

Menyanthes trifoliata pollen and seeds both can be confidently identified from the upper part of the Buckbean fen core (pls. 3 and 6). The plant now grows on the fen and elsewhere in the park.

\section{NYMPHAEACEAE}

Nuphar luteum ssp. polysepalum is distinct from eastern subspecies of the species because of its longer seeds (pl. 7). Pollen of this genus is also well represented and is easily identified by its monosulcate, echinate grains (pl. 2).

\section{ONAGRACEAE}

Epilobium seeds are found in several cores and in a surface sample. The Epilobium lactiflorum seed that occurs in Lilypad pond is small and has parallel rows of separate, long, narrow tubercles (pl. 8). The specimens in the Pinus contorta zone of Buckbean fen are more elongate, with rows of short projections; the rows are connected by low crossbars (pl. 8). They are referred to Epilobium glandulosum type which includes $E$. adenocaulon.

\section{POLEMONIACEAE}

Pollen of Polemonium (pl. 3) is distinct from other genera in the family, because of its striate or striate-reticulate sculpture and its periporate apertures (Stuchlik, 1967). Reference collections were insufficient to attempt a specific identification.

\section{POLYGONACEAE}

Pollen of Polygonum (including Bistorta) can be separated into three types. Bistorta type is tricolporate, tectate, prolate, and psilate, with prominent columellae; it has slitlike furrows and an equidimensional pore ( $\mathrm{pl}$. 3). Polygonum persicaria type is periporate with a coarse reticulum. Polygonum ramosissimum type is tricolporate, prolate, and psilate, but with transverse furrows. Bistorta type includes Bistorta bistortoides and Bistorta vivipara, both subalpine to alpine plants. Because of incomplete reference material, species included in the other two types are unknown.

Single pollen grains of Koenigia and Oxyria type were found at $850 \mathrm{~cm}$ in Buckbean fen. Koenigia pollen is periporate, echinate, and tectate, with about 12 small, elongate pores. The fossil is about $22 \mu \mathrm{m}$ 
(micrometres) in diameter, whereas the reference material is about $25 \mu \mathrm{m}$. Oxyria-type pollen is spheroidal, tricolporate, psilate, and tectate, with slit-shaped furrows and small pores. Both plants are restricted to arctic-alpine environments, and Koenigia is rare in the modern flora of the tundra in the Rocky Mountains (Weber, 1967).

The pollen of Eriogonum or Rumex could not be separated into morphological types. However, one fragmentary and one whole seed of Rumex salicifolius (pl. 6) suggest that Rumex pollen (pl. 4) belongs to that species in the Picea-Juniperus-Pinus albicaulis zone. The seeds also resemble the adventive $R$. crispus but are distinct in size and shape from other native species. Rumex fueginus seeds and perianths are present in the Pinus contorta zone of Buckbean fen and they are abundant in the upper zones of other cores in the area. The distinctive denticulate valves of $R$. fueginus (pl. 6) distinguish it from all other species. The separate seeds closely resemble those of $R$. paucifolius.

\section{RANUNCULACEAE}

Only two fruits of Ranunculus aquatilis were found (pl. 8). The distinctive ribbed achenes distinguish it from all other species of Ranunculus.

\section{ROSACEAE}

Potentilla seeds were difficult to identify as to species because of the large number of species in the Rocky Mountain area. The Potentilla cf. gracilis is smaller than all the reference material, but it comes closest in size and shape to Potentilla gracilis (pl. 8). Potentilla biennis type matches both the striated seeds of $P$. biennis and $P$. norvegica (pl. 8). For plant-geographical and autoecological reasons, the seeds are referred to as $P$. biennis. The large, broad seeds of $P$. palustris are distinct from all other species (pl. 8), and the striate pollen is also distinctive (pl. 4). Sibbaldia procumbens, a genus closely related to Potentilla, has larger and broader seeds distinct in shape from species of Potentilla. It is a subalpine and alpine plant.

\section{SALICACEAE}

The bracts referred to Populus balsamifera (pl. 6) also resemble Populus trichocarpa. The former is a boreal forest tree extending from Northeastern United States through western Canada with disjunctions south to the Yellowstone National Park area (Fowells, 1965). Populus trichocarpa is a west coast tree whose distribution extends inland to the Yellowstone National Park area (Fowells, 1965). Their present ranges overlap, and the acceptance of Populus balsamifera in Yellowstone National Park by McDougall and Baggley (1956) is in need of verification. Fossils of these two species are difficult to distinguish, but bracts of $P$. balsamifera are narrower than those of $P$. trichocarpa in our material. Populus trichocarpa grows along streambanks and flood plains at low elevations. Populus balsamifera is not strictly riparian, and it grows in the montane and subalpine zones up to 11,000 feet (Porter, 1967; Weber, 1967). Ecological and morphological considerations support the referral of the fossil bracts to Populus balsamifera, and the pollen probably is of this species also (pl. 4).

A fairly distinct morphologic type of Salix pollen (pl. 4) was found in some alpine surface samples. Inadequate reference material for this genus has made careful study unwarranted. Buds of Salix have not been identified to species, but a few leaf bases can tentatively be referred to Salix subcoerulea. Seed and leaf reference collections are also incomplete for this genus.

SAXIFRAGACEAE

A single seed of Saxifraga caespitosa was found in the Lilypad pond core (pl. 10). The seed is ovate-oblong and has a surface pattern of linear rows of tiny beadlike projections. Only Saxifraga rivularis has a similar beaded pattern, but in that species the beads form a reticulum. I have collected Saxifraga caespitosa from the Two Ocean Plateau and from the Beartooth Plateau, and it is an alpine species.

Another saxifrage seed is referred to Saxifraga rhomboidea (pl. 10). It also is ovate-oblong, and its surface is traversed by discontinuous, often indistinct ridges. This species ranges from the plains to the alpine tundra.

\section{CYPERACEAE}

Although the genus Carex is represented by many species in the Rocky Mountain region, collections from wet-ground species in Yellowstone National Park have allowed several species to be identified from their fruits. Usually the perigynium, an inflated sac covering the achene, must be present for identification.

Several fruits with perigynia of Carex aquatilis were found (pl. 9). Separate achenes, when preservation was excellent, were placed in this species, but others less well preserved or with different morphology were placed under Carex biconvex. Carex aquatilis is the commonest of the Carex species with biconvex achenes that grow in wet places in Yellowstone National Park.

Carex canescens fruits are biconvex and their small plump perigynia are strongly veined (pl. 9). Carex diandra fruits (pl. 9) have a corky-based perigynium that tightly encases the achene. The achenes are shaped somewhat like Scirpus fruits, but they are round rather than biconvex in cross section. Achene 
and perigynium are usually found together but can be recognized separately. Carex limosa fruits were never found with perigynia. The achenes are weakly triangular to round in cross section, obovate, and usually indented in one side (pl. 7). They match reference material perfectly, and Carex limosa grows at present in the Carex diandra-Potentilla palustris community on the fen. Carex vesicaria and $C$. utriculata are two other species now common on the fen. Their perigynia are distinguished by shape; $C$. vesicaria perigynia taper gradually to a slender base, whereas those of $C$. utriculata are abruptly expanded to a broader base (pl. 7).

A single Eleocharis macrostachya fruit, corroded but identifiable, was found in the Buckbean fen core (pl. 9). These fruits are much more common in other cores from this area. These biconvex fruits with the small, broad-based tubercle connected only at the top of the fruit are easily separable from other species in the area.

\section{GRAMINEAE}

Seeds of this family generally have thin seed coats and only a few genera with thick seed coats fossilize. Spikelets of Calamagrostis are abundant in one macrofossil surface sample from Buckbean fen but are not found as fossils. Calamagrostis canadensis and $C$. inexpansa are common on the fen surface today, and they probably grew there throughout most of postglacial time.

Seeds of Glyceria maxima ssp. grandis are present at only one horizon of the Buckbean fen core but are abundant in other cores from the area (pl. 9). This species has seeds similar to $G$. borealis, but the seed tip is blunt in G. maxima and sharp in G. borealis. The reference specimens are somewhat larger than the fossil material. Other species are quite different in morphology and size.

\section{NAIADACEAE}

Seeds of Naias flexilis are easily distinguishable from other species in the genus by size and surface texture (pl. 9). This species is not reported from the present flora of Wyoming or Colorado, though it does occur in Utah (Porter, 1963; Matsumura and Harrington, 1955). I have found seeds of Naias flexilis in approximately the midpostglacial from four ponds in Yellowstone National Park. The plant probably grows in Wyoming and Colorado, but it is unreported because it is inconspicuous and because aquatic plants are not commonly collected.

Several species of Potamogeton have very distinctive fruit-stones, and many of the North American species are treated in keys (Jessen, 1955; Martin and Barkley, 1961). In Potamogeton alpinus the lid reaches the top of the fruit-stone and is remote from the style base. One specimen was found with its soft outer covering intact (pl. 7). Potamogeton filiformis fruit-stones also have the lid remote from the style base, but the lid does not reach the top of the fruit-stone (pl. 7). It is similar to but smaller than fruit-stones of $P$. vaginatus and $P$. pectinatus. $P$. gramineus fruit-stones are rather small with a low central depression and a low-keeled lid (pl. 7). One fruit-stone without a lid best matches $P$. illinoensis, but certain identification is not possible. It occurs with a fruit-stone of $P$. alpinus.

\section{TYPHACEAE}

Fruits of Typha cannot be identified to species (pl. 10). Pollen of Typha latifolia remains in tetrads, so this species is recognizable (pl. 2). Typha angustifolia pollen cannot be distinguished from pollen of Sparganium or broken tetrads of Typha latifolia, and the pollen is here called Sparganium type because fruits of Sparganium angustifolium and $S$. minimum have been found in other nearby cores.

\section{OTHER TYPES OF FOSSILS}

Other types of macrofossils were tallied on a scale from one (rare) to five (very abundant). No attempt was made to differentiate among bryophyte spores, although the one shown on plate 1 is the commonest type. Abundance of Sphagnum leaves was noted, because the two types of cells in the leaves make them easy to recognize.

\section{ALGAE}

Pediastrum colonies (pl. 4) were counted and plotted in the pollen diagram (fig. 15) because they indicate an aquatic environment. They are present in many surface samples, especially those from larger or deeper ponds.

Oogonia of charophytes were tallied in the macrofossil diagrams (figs. 17 and 18). They disappear above $820 \mathrm{~cm}$ in the Buckbean fen core, but they are present in younger horizons from other cores in the area.

One species of diatom (Melosira?) was large enough to be caught by the 140 -mesh sieve; specimens were sent to R. C. Bright for identification. The species occurs below $800 \mathrm{~cm}$ in Buckbean fen and Lilypad pond cores.

Statoblasts of freshwater bryozoa and shells of rhizopods were not further identified. Both occur mainly in the small pond stage of the Buckbean fen core in the interval $275-475 \mathrm{~cm}$.

\section{DESCRIPTION OF POLLEN ZONES PICEA-JUNIPERUS-PINUS ALBICAULIS ZONE $(960-770 \mathrm{~cm})$}

The basal zone is defined by relatively low $(30-50$ percent) Pinus pollen (dominantly Pinus albicaulis 
type) and by maxima in Picea, Abies, Juniperus, Salix, Artemisia, Gramineae, Compositae (subfamilies Tubuliflorae and Liguliflorae), and Rumex (fig. 15). A mixture of subalpine and alpine macrofossils is present in this zone, and large diatoms (longer than $0.5 \mathrm{~mm}$ ) and charophytes are nearly limited to this zone (figs. 17 and 18). The concentration of the alga Pediastrum reaches 40 percent of the pollen sum at the base, and bryophyte spores are consistently present.

This pollen zone occurs in the lower $190 \mathrm{~cm}$ of the core from Buckbean fen and the lower $200 \mathrm{~cm}$ of the Lilypad pond core (figs. 15, 17, and 18). The sediment in both sections overlies a basal gravel and consists of $100-200 \mathrm{~cm}$ of gray sandy silts (table 5). The sandy silts in this zone contain too little carbon for $\mathrm{C}^{14}$. dating, but on the basis of two other dates on deglaciation (Sullivan and others, 1970; Bender and others, 1971) the sediments in this zone probably began to accumulate before 13,500 years ago. Also, an ash layer near the base of the Lilypad pond core (table 5) may represent the Glacier Peak ash dated at 12,000 years B.P. (Wilcox, 1965), but the ash was too thin and mixed with sediment to be identified. The age of the sediments at the top of the zone is unknown here, but the top of the correlative zone at Cub Creek pond is dated by $\mathrm{C}^{14}$ at $11,630 \pm 180$ years B.P. (I -2285 , Waddington and Wright, 1974). The zone is divided into two subzones on the basis of pollen and plant macrofossils: a lower Betula subzone and an upper Populus subzone.

\section{BETULA SUBZONE $(960-875 \mathrm{~cm})$}

The Betula subzone is defined primarily by low but persistent values ( $1-3.5$ percent) of Betula pollen (fig. 15). Rumex (dock) pollen is consistently present, and Compositae pollen, especially subfamily Liguliflorae, is most common in this subzone. Pinus albicaulis/ Pinus contorta ratios are highest in this subzone, ranging from 5.5 to 27 (fig. 19).

The lower $100 \mathrm{~cm}$ of the Lilypad pond core (fig. 18) is tentatively referred to this subzone on the basis of (1) presence of mixed alpine- and subalpine-plant macrofossils, (2) distribution of Betula glandulosa (bog birch) fruits and catkin scales, and (3) rare presence of arboreal macrofossils. The Cub Creek pond sequence (Waddington and Wright, 1970) shows a similar Betula pollen peak at the base of the core.

Betula glandulosa and Rumex salicifolius (willow dock) were identified from macrofossils from the Lilypad pond core (fig. 18), and these are probably the species represented by pollen (fig. 15). The Betula pollen is small mostly less than $21 \mu \mathrm{m}$ in diameter. Betula glandulosa is a common shrub of wet subalpine areas in the Rocky Mountains (Weber, 1967). Rumex
TABLE 5.-Lithologic description of Buckbean fen and basal section of Lilypad pond

$\begin{array}{ccc}\begin{array}{c}\text { Penetration } \\ (\mathrm{cm})\end{array} & \begin{array}{c}\text { Core length } \\ (\mathrm{cm})\end{array} & \text { Description }\end{array}$

Buckbean fen

$0-100 \quad 0-81$ Sedge peat, dark-brown fibrous; with intertwined rootlets. Rootlets of woody plants (Salix spp?) from $0-10 \mathrm{~cm}$.

$100-200100-188$ Sedge peat, dark-brown, somewhat decomposed; not so fibrous as $0-81 \mathrm{~cm}$, coarse Carex leaves from $100-115 \mathrm{~cm}$; abundant bryophytes from $130-188 \mathrm{~cm}$.

$200-300200-290$ Sedge peat, brown, somewhat decomposed, with bryophytes common.

$300-400300-383$ Peat, brown, with sedge remains, wood fragments, and Nuphar seeds from $300-$ $340 \mathrm{~cm}$; mainly bryophyte peat from 340 $383 \mathrm{~cm}$.

$400-500400-487$ Bryophyte peat, brown from $400-410 \mathrm{~cm}$, grading to olive-colored gyttja at $425 \mathrm{~cm}$. Fine-grained detrital peat from $430-487$ cm, black from $430-442 \mathrm{~cm}$, brown from $442-487 \mathrm{~cm}$.

$500-600500-585$ Gyttja (organic sediments of eutrophic lakes), brown, silty, fine-grained, inelastic, crumbly.

$600-700$ 600-699 Gyttja, brown, silty, fine-grained, inelastic crumbly from $600^{-}-620$, solid from $620-$ $640 \mathrm{~cm}$.

$700-800700-783$ Gyttja, brown, silty, clayey, inelastic; crumbly from $700-710$ and $751-783 \mathrm{~cm}$, firm elsewhere, dark band from $717-722$.

$800-890 \quad 800-884$ Silt, organic, highly diatomaceous; finely laminated (varved?) from $810-856 \mathrm{~cm}$ crumbly from $800-820 \mathrm{~cm}$, very firm from $820-84 \mathrm{~cm}$, sand layer at $805 \mathrm{~cm}$, becoming gray silt mottled with dark spots from $856-884 \mathrm{~cm}$. Sand lense at $873 \mathrm{~cm}$.

$890-975890-960$ Silt, gray, sandy, highly diatomaceous, with dark mottling from $890-928 \mathrm{~cm}$, lenses of gray medium-grained sand at 910 and 951.5 - $954.5 \mathrm{~cm}$, crumbly from 939-945 $\mathrm{cm}$, firm elsewhere. Pebbles impacted into bottom of core.

Lilypad pond

$800-900800-892$ Silt, gray, sandy, highly diatomaceous below $825 \mathrm{~cm}$, sand layer at $854-855 \mathrm{~cm}$ streaks of black sand at 881 and $883.5 \mathrm{~cm}$, gray clay from $887-890 \mathrm{~cm}$, laminated brown and buff silt from $890-892 \mathrm{~cm}$.

900-1,000 900-1,000 Clay, gray, sticky, from $907-910 \mathrm{~cm}$; coarse gray sand from $900-907$ and $910-917 \mathrm{~cm}$. Silt from $917-1,000 \mathrm{~cm}$ : gray, sandy dark layers at $950,953.4,996.5$, and 997.5 $\mathrm{cm}$; ash layer at $974.2-974.5 \mathrm{~cm}$.

salicifolius grows on dry sites at elevations from 3,500 to 9,500 feet in Wyoming (Porter, 1968).

Several local habitats are suggested by the pollen and macrofossils (figs. 15, 17, and 18). Rumex salicifolius, Potentilla cf. gracilis, and Descurainia californica are weedy species that probably grew in dry, disturbed areas or along the shores of the ancestral lake. Juniperus (probably J. communis) and various composites may have shared dry forest openings with these species. Pollen of steppe 


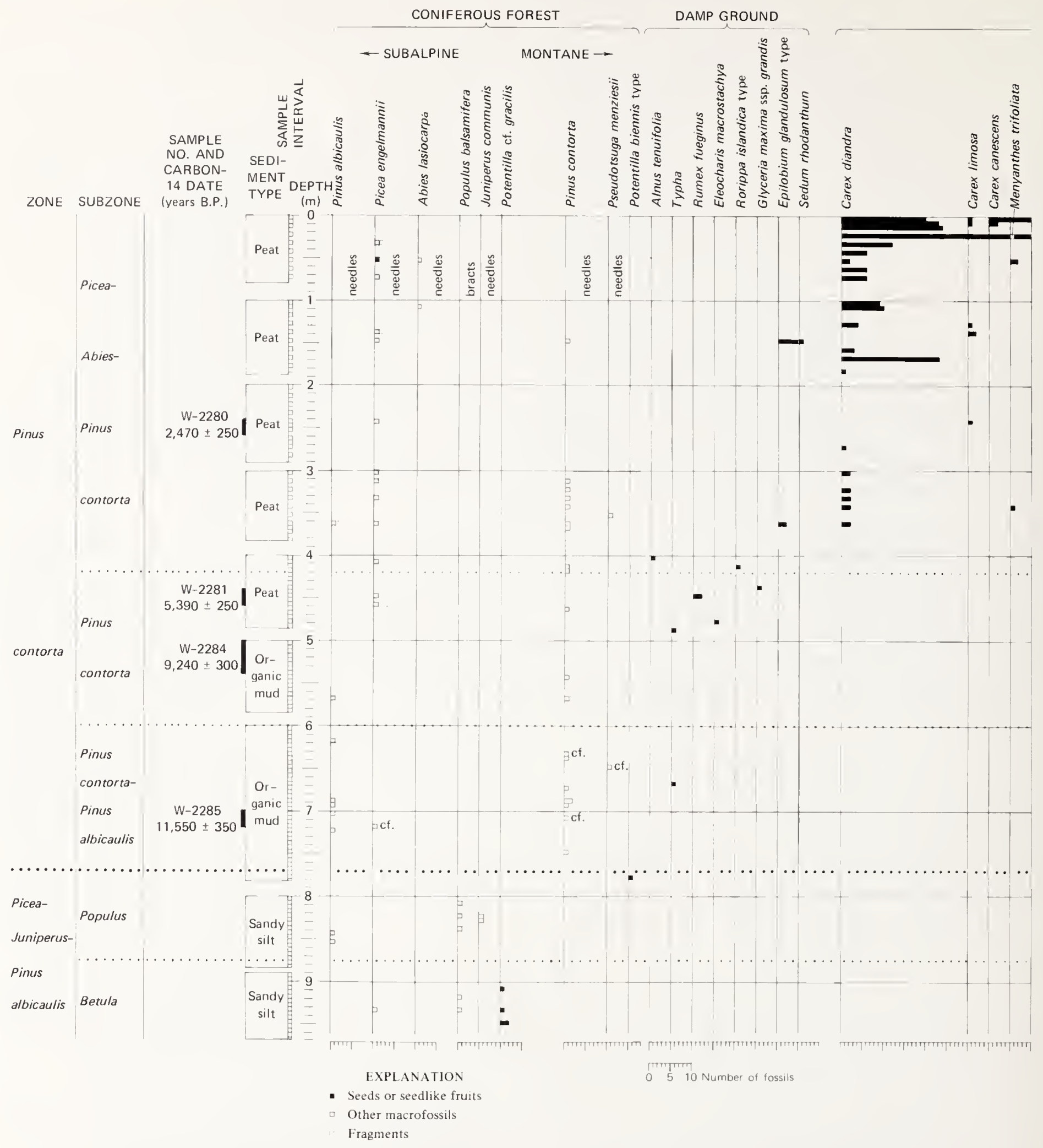

Figure 17 (above and right). - Plant macrofossils from Buckbean fen core.

elements, such as Artemisia, Cheno-Ams, and Sarcobatus, is common in this subzone, but it seems ecologically unreasonable that these plants grew near the coring sites. Woodland or tundra species of Artemisia may have contributed some pollen, but long-distance transport probably accounted for much of the pollen of steppe elements, as it apparently does at present in alpine sites.

Pollen of Potamogeton, fruit-stones of Potamogeton alpinus and $P$. filiformis, and fruits of Ranunculus 


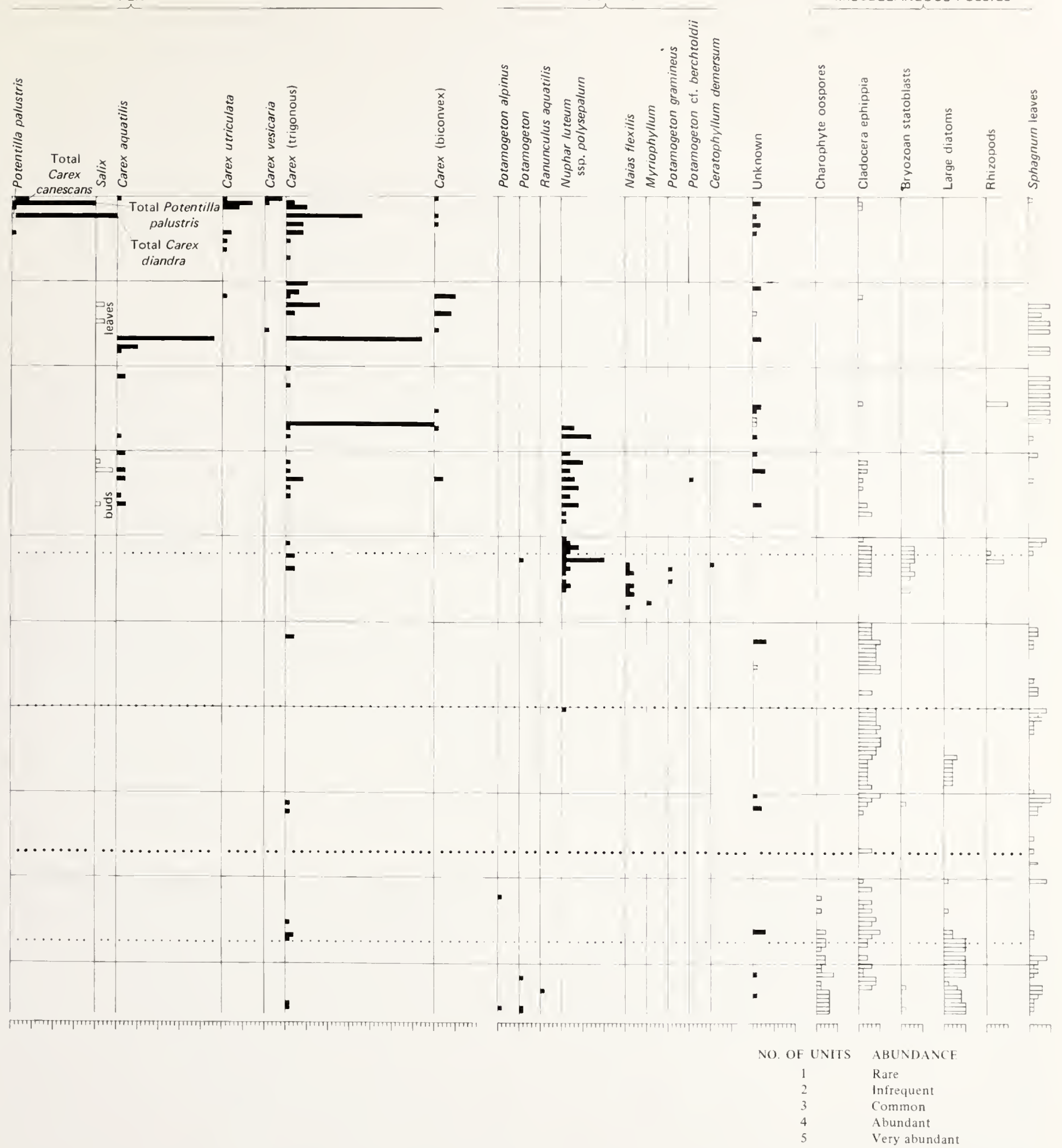

aquatilis (water crowfoot) indicate that pioneer aquatics had colonized the shallow lake margins. A few pollen grains of Typha latifolia (broadleaf cattail) and Sparganium (burreed) type suggests that these plants may also have grown in shallow water or along the shore (figs. 15, 17, and 18).
Macrofossils of Saxifraga caespitosa, S. rhomboidea, Potentilla sp., Sibbaldia procumbens, and Betula glandulosa, and pollen of Bistorta and Polemonium suggest that subalpine or alpine meadows were present in the area (figs. 17 and 18). These plants at present are common in the alpine parts of the Two 


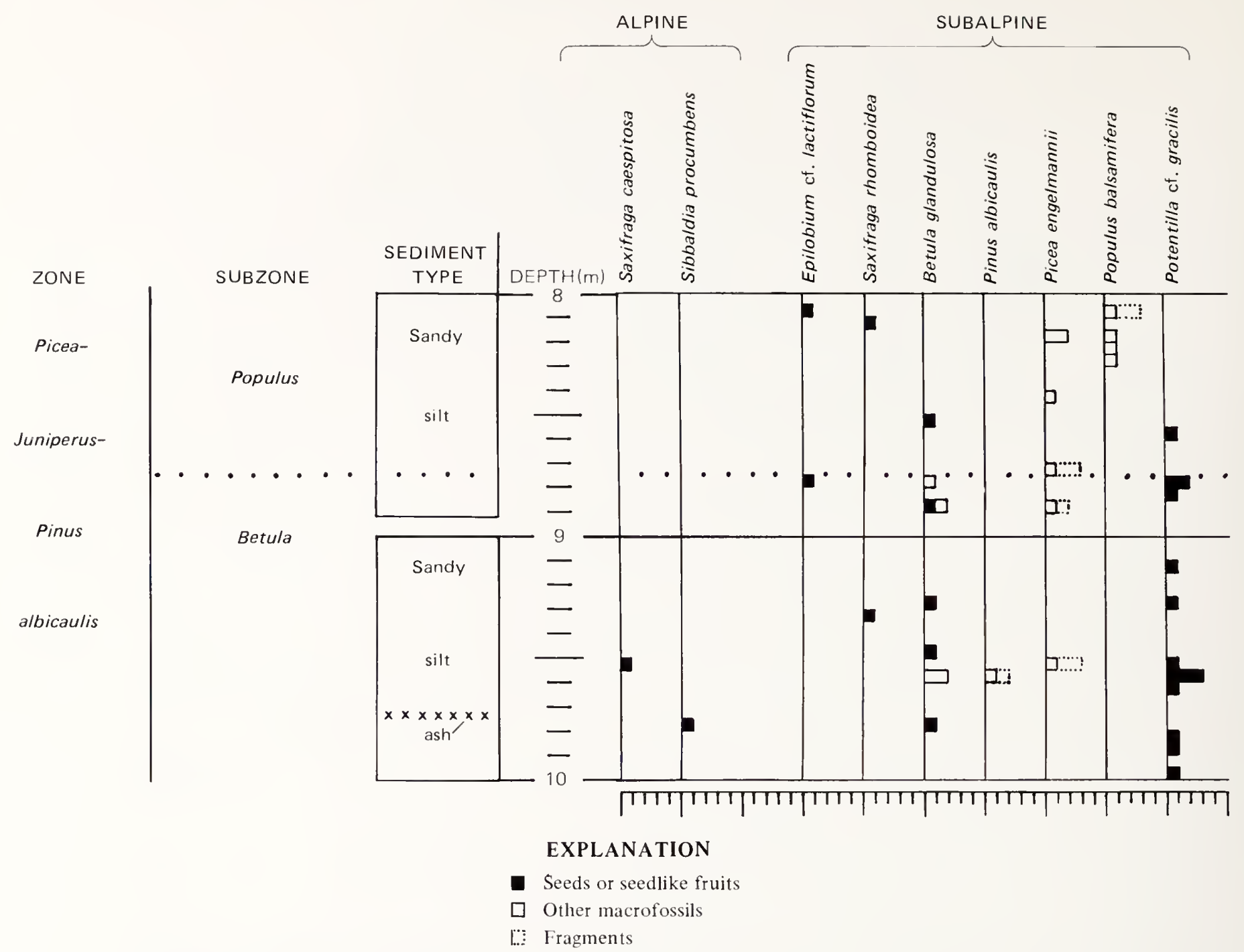

FIGURE 18 (above and right). - Plant macrofossils from lower 2 metres of Lilypad pond core.

Ocean Plateau, but only Saxifraga caespitosa is limited to the alpine tundra.

Rare Picea and Pinus albicaulis needles and a Populus bract suggest that only a few trees may have grown in favorable nearby habitats (figs. 17 and 18). Pollen percentages of Picea, Abies, and nonarboreal types compare best with modern surface samples from low alpine and parkland sites (figs. 13 and 15). Pinus pollen values are about 20 percent lower in the Betula subzone than in these surface samples. Low tree-pollen percentages might be expected at that time if the surface of the plateau was covered by tundra or mixed parkland and tundra instead of forest. Pollen ratios also support the conclusion that the site was near timberline during Betula subzone time. Pinus albicaulis/Pinus contorta and Gramineae/Pinus ratios are high $(1-11$ and $0.025-0.2)$ in modern surface samples collected at or above timberline (fig.
14). Both ratios are high $(5.5-11$ and $0.1-0.33)$ in the Betula subzone (fig. 19).

The proximity of trees to the coring site is difficult to determine. No nearby forested areas below this tundra or parkland were present, because the ancestral lake covered all lower ground in the vicinity. Conifer needles can blow for some miles when caught in the updraft of large forest fires. R. F. Bucknam and B. B. Kropf (written commun., 1969) reported conifer needles falling in Denver, Colo., during a forest fire on Mount Evans, which lies about 35 miles west and at least 6,000 feet higher. All the needles were carbonized, however, whereas most needles from the Betula subzone in the core studied were not.

Picea, Abies, Pinus albicaulis, and possibly Populus balsamifera (balsam poplar) were probably the only trees growing on the plateau parklands at this time. Pinus contorta type pollen percentages of less than 2 


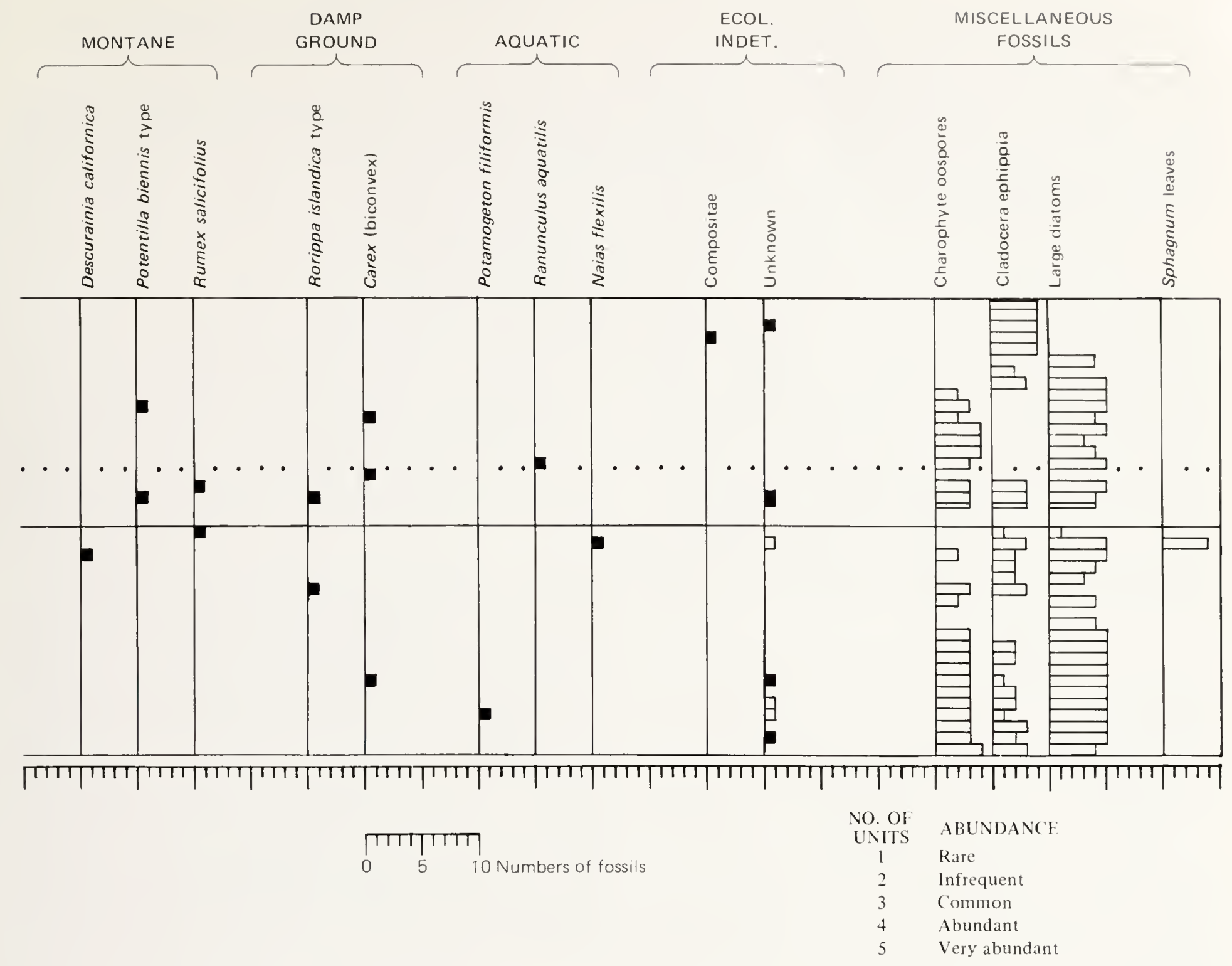

percent (fig. 15) suggest that this tree was not present on the Yellowstone plateau, although it probably grew in lowlands around the margins of the plateau.

Trees apparently did not require a long time to migrate onto the plateau after the melting of the icecap. The high ridges and plateaus in the southern and eastern parts of the park would have been above climatic treeline during this time and would have acted as barriers to migration. Migration probably took place along valleys, progressing gradually inward to the Southeast Arm of Yellowstone Lake as the valleys became free of ice. Scattered trees may have been present within a few miles of the coring area when it first became exposed.

An alternate hypothesis for forest migration would be that trees survived locally on nunataks and migrated a shorter distance down to the coring area.
However, no nunataks are known nearby that would have been below the climatic treeline.

The pollen and macrofossils of this subzone suggest subalpine to alpine vegetation and a cold, wet climate. Present lack of climatic stations in the subalpine and alpine areas of Yellowstone National Park makes it difficult to quantify the late-glacial climate, but average July temperature below $50^{\circ} \mathrm{F}$ now characterizes the areas above treeline (Marr and others, 1968) or north of it (Wolfe and Leopold, 1967). If subalpine spruce-fir-whitebark pine parkland occurred near Yellowstone Lake, such conditions probably prevailed.

$$
\text { POPULUS SUBZONE }(875-770 \mathrm{~cm})
$$

The Populus subzone of the Picea-Abies-Pinus albicaulis zone is defined by a peak in Populus pollen and by bracts of Populus balsamifera (figs. 15, 17, and 
18). A peak in the curve for Ambrosia also occurs in this subzone (fig. 15). Alpine-plant macrofossils are no longer present, Picea and Pinus albicaulis needles are more common, and Juniperus communis needles appear (figs. 17 and 18). Pinus albicaulis/Pinus contorta and Gramineae/Pinus ratios decrease throughout this zone and range from 1.1 to 7.5 and from 0.047 to 0.228 , respectively (fig. 19).

Several local habitats may be inferred from the fossils in this subzone. Betula glandulosa, Potentilla cf. gracilis, Rorippa islandica (marshcress) type, and Epilobium cf. lactiflorum (pale willow-herb) macrofossils (fig. 18) suggest a moist subalpine meadow nearby. A dry, open subalpine environment, such as might have been found near the shores of Yellowstone Lake, is inferred from macrofossils of Rumex salicifolius and Potentilla biennis type. The fossil aquatic flora includes Ranunculus aquatilis, Potamogeton alpinus, and Naias flexilis (naiad). Naias flexilis is not reported from the modern floras of Wyoming or Colorado. Single pollen grains of Oxyria

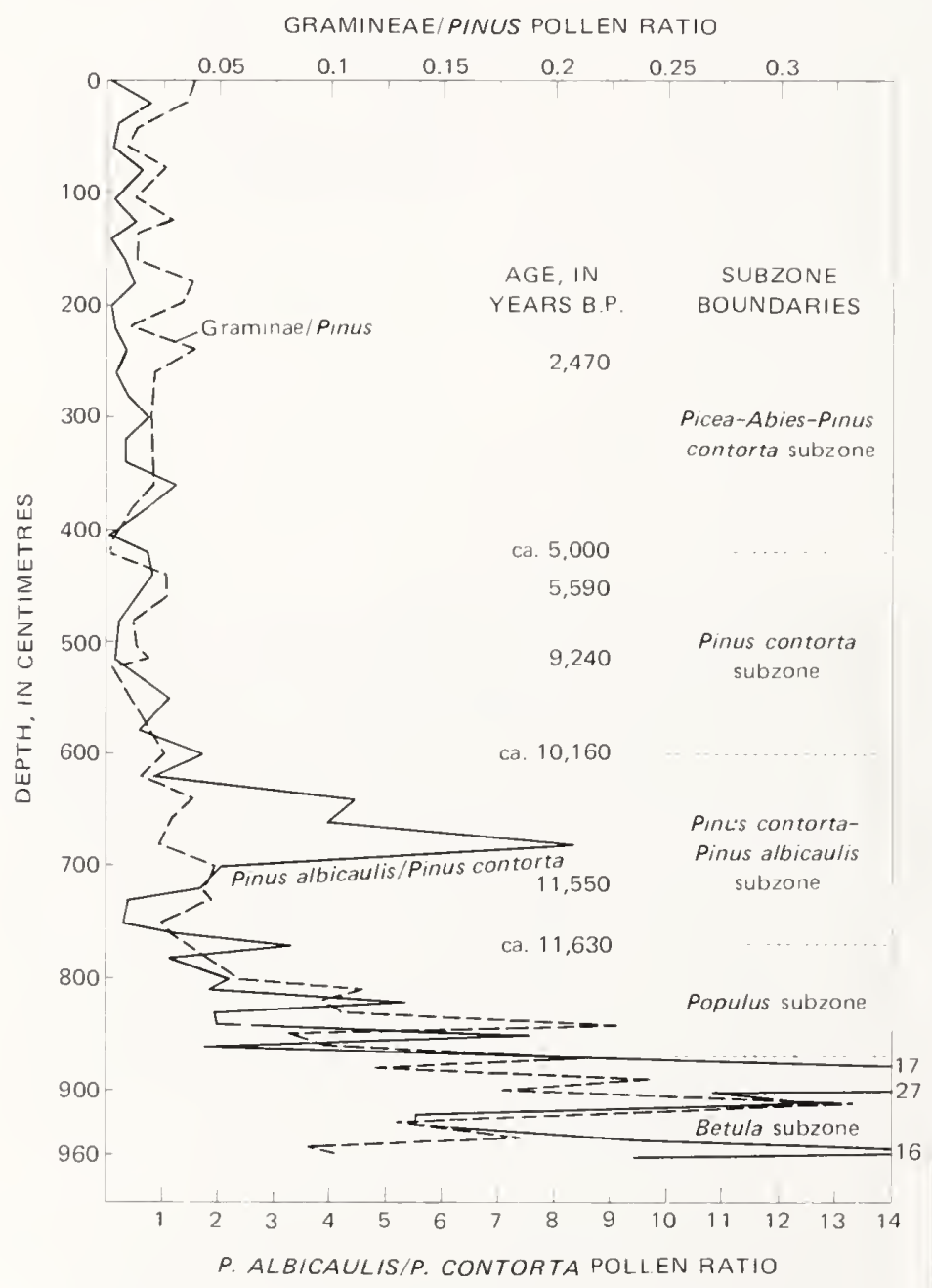

Figure 19.-Ratios for fossil pollen from Buckbean fen. (alpine sorrel) and Koenigia islandica at $850 \mathrm{~cm}$ suggest that alpine plants may have persisted for a while on exposed sites.

Picea engelmannii, Pinus albicaulis, Populus balsamifera, and probably Abies lasiocarpa were present locally in a subalpine parkland environment. This interpretation is suggested by analogy with surface samples and from the composition of the pollen and plant-macrofossil spectra. A closed Picea-AbiesPinus albicaulis forest is ruled out by the high nonarboreal pollen curves and high Gramineae/Pinus ratios that typify surface samples from modern parkland or tundra (figs. 14, 15, and 19).

Populus balsamifera probably was a pioneer species along the shores of Yellowstone Lake, perhaps as early as during the previous subzone. Populus trichocarpa (black cottonwood), a closely related species, is an early migrant onto deglaciated surfaces in southeast Alaska (Lawrence, 1958). Populus pollen maxima indicate that it was an early migrant in northwest Minnesota after deglaciation (McAndrews, 1967), and macrofossils of three species, including $P$. balsamifera, were found in sediments of late glacial age in southern Manitoba (Ritchie and de Vries, 1964).

To summarize the environments of the Picea-AbiesPinus albicaulis zone, the basal subzone represents an environment at or slightly above timberline with few, if any, trees present. During the time of the upper subzone, trees were present in a subalpine parklandtype vegetation. The climate for this zone was probably comparable to that of the high subalpine or low alpine associations today in Yellowstone Park. Treeline was approximately 2,000 feet lower than it is today.

\section{PINUS CONTORTA ZONE $(770-0 \mathrm{~cm})$}

This zone is defined by high percentages $(65-88$ percent) of the total pine pollen and by Pinus contorta macrofossils (figs. 15 and 17). Artemisia declines from more than 20 to less than 10 percent in this zone, and values of Juniperus, Picea, Abies, Betula, and most nonarboreal pollen are low (fig. 15).

The sediments in this zone are silty gyttja in the interval $770-500 \mathrm{~cm}$, transitional organic detritus in the interval $500-410 \mathrm{~cm}$, and peat from $410 \mathrm{~cm}$ to the surface (table 5). No dates are available from sediments at the base of this zone, but a date at the zone boundary at Cub Creek pond is $11,630 \pm 180$ years B.P. ( sample I-2285; Waddington and Wright, 1970).

The zone is divided into the following three subzones: the Pinus contorta-Pinus albicaulis subzone $(770-600 \mathrm{~cm})$, the Pinus contorta subzone $(600-420$ $\mathrm{cm})$, and the Picea-Abies-Pinus contorta subzone $(420-0 \mathrm{~cm})$ (fig. 15, table 3$)$. 
PINUS CONTORTA-PINUS ALBICAULIS SUBZONE $(770-600 \mathrm{~cm})$

This subzone is defined by a resurgence of Pinus albicaulis/Pinus contorta ratios up to 8.3 (fig. 19), and the occurrence of needles of both pine species (fig. 17). Pinus pollen percentages average 65 - 70 percent, and Artemisia ranges from 15 to 20 percent (fig. 15). Arceuthobium (dwarf mistletoe) is persistently present, and a few grains of Pseudotsuga occur. Concentrations of Picea, Abies, Juniperus, Populus, Betula, Salix, Ambrosia, Compositae, and Gramineae, all significant in the lower subzones, are several times lower in this subzone (fig. 15).

A radiocarbon date near the base of this subzone gives an age of $11,550 \pm 350$ years B.P. The age of the top of this subzone is interpolated to be 10,160 years B.P. (figs. 15 and 16, table 3 ), using the rate of sedimentation calculated from adjacent radiocarbon dates.

The pollen spectra from this subzone compare approximately with modern surface samples from forest openings (fig. 13). Gramineae/Pinus ratios for this subzone are between 0.025 and 0.050 ; these ratios are lower than those of modern surface samples in forest openings and parklands but higher than ratios in closed forests (figs. 14 and 19). An open, mixed forest with Pinus contorta, Pinus albicaulis, and Pseudotsuga menziesii probably grew in the area during the interval represented by this subzone. (Pollen values of Pseudotsuga as low as 1 percent probably indicate its local presence, based on surface samples.) The most significant change in vegetation after deposition of the lower zone was the arrival of Pinus contorta and Pseudotsuga in the coring area (figs. 15 and 17).

It is difficult to infer other habitats that might have been present during this period because few macrofossils other than pine needles are present. A few Carex fruits and a Typha fruit (fig. 17) suggest a possible pond-shore habitat.

Persistence of Arceuthobium in the pollen profile, beginning at $730 \mathrm{~cm}$ (fig. 15), gives evidence for a tentative mean annual temperature during that time. Its pollen appears at about the same level that Pinus contorta needles first appear (fig. 17). I could not determine the species using pollen morphology, but it is probably Arceuthobium americanum, a parasite that occurs exclusively on Pinus contorta in this region. It is the only species of Arceuthobium reported from the park by McDougall and Baggley (1956), but Hawksworth and Wiens (1972) reported $A$. douglasi, a parasite on Pseudotsuga, from the park as well. At present the upper limits of Arceuthobium americanum coincide with the $30^{\circ} \mathrm{F}$ mean annual isotherm in Colorado and Wyoming (Gill, 1957), suggesting that the temperature when Arceuthobium first appeared was about the same as it is now.

The coexistence of Pinus contorta, Pinus albicaulis, and probably Pseudotsuga menziesii, and the low values of Picea and Abies suggest a climate drier than the climate of the preceding zone and also the present climate.

\section{PINUS CONTORTA SUBZONE $(600-420 \mathrm{~cm})$}

This subzone is defined by $70-80$ percent Pinus pollen, low ratios of Pinus albicaulis/Pinus contorta pollen, and needles of Pinus contorta (figs. 15, 17, and 19). Pseudotsuga pollen is less common than in the preceding subzone, and Picea and Abies are low throughout. Artemisia pollen ranges from 10 to 15 percent, and Arceuthobium and Alnus are present at low but persistent values (fig. 15).

A sediment sample from interval $500-541 \mathrm{~cm}$ in the Buckbean fen core gives a $\mathrm{C}^{14}$ date of $9,240 \pm 300$ years B.P. (W - 2284). Another sample from interval $440-460 \mathrm{~cm}$ is dated at $5,390 \pm 250$ years B.P. (W-2281). Interpolation between older and younger dates suggests that this subzone began about 10,160 years ago and ended about 5,000 years ago (fig. 15, table 3 ), but the 4,000-year span of the dates in the zone, over only a $70-\mathrm{cm}$ interval, suggests a hiatus in the core. (See fig. 16.)

The fossil assemblage suggests that a virtually pure Pinus contorta forest was the dominat vegetation association around the coring site during this period. Fossils from local vegetation types are poorly represented, especially from interval $600-487 \mathrm{~cm}$ in this subzone.

From interval $487-420 \mathrm{~cm}$, macrofossils of Nuphar luteum ssp. polysepalum, Naias flexilis, Myriophyllum sp. (watermilfoil), Potamogeton gramineus, and Ceratophyllum demersum (hornwort) and pollen of Nuphar and Myriophyllum suggest a small, warm-water pond habitat (fig. 17). The presence of this habitat requires that Yellowstone Lake had fallen to a level within 15 feet of its present level by about 5,000 years ago.

One fragment of an Alnus tenuifolia (thinleaf alder) fruit at $405 \mathrm{~cm}$ (fig. 17) suggests that the Alnus pollen is also of that species. It is the only species of Alnus that now occurs in Wyoming (Porter, 1967), and it suggests that the habitat was the margin of a lake, pond, or fen.

Macrofossils of Glyceria maxima ssp. grandis (large mannagrass), Rumex fueginus, Carex utriculata, and 
Typha sp. also provide evidence for a wet-ground vegetation around the margins of the pond (fig. 17).

\section{PICEA-ABIES-PINUS CONTORTA SUBZONE $(420-0 \mathrm{~cm})$}

This subzone is defined by low but persistent values of Picea and Abies pollen, by their macrofossils, and by low pollen ratios of Pinus albicaulis/Pinus contorta (figs. 15 and 19). The Artemisia curve is at its lowest (4-10 percent) in the entire core. Cyperaceae pollen percentages are high but irregular in the subzone, but macrofossils indicate that the pollen comes from local fen species of Carex (figs. 15 and 17).

A sample from interval $240-260 \mathrm{~cm}$ gave a $\mathrm{C}^{14}$ date of $2,470 \pm 250$ years B.P. $(W-2280)$. The subzone represents the period from about 5,000 years ago by interpclation to the present. An interpolated date of 2,800 years B.P. marks a rise in Picea, Abies, and Cyperaceae pollen percentages (figs. 15 and 16, table 3).

Pollen and macrofossils of Pinus contorta, Picea, and Abies indicate that these trees were dominant in the forest association when this subzone was deposited (figs. 15 and 17). Pollen and a needle of Pseudotsuga menziesii and a needle of Pinus albicaulis type suggest that these trees may have been present early during this period, but they played a decreasing role in the forest association.

Most Picea needles in this subzone are charcoal. Frequent fires nearby might explain the carbonization, though other conifer needles are not charcoal. No prominent charcoal layers were observed in this core, but charcoal is abundant in some horizons of other cores taken in the area. Fires would favor propagation of Pinus contorta (Tackle, 1961) and might tend to eliminate Picea and Abies from the forest. However, no injurious long-term effects of fire on Picea and Abies can be recognized in the pollen diagram (fig. 15).

Changes in the local environment are well documented in this subzone by plant macrofossils (fig. 17). From interval $420-375 \mathrm{~cm}$, macrofossils of aquatic and pond-margin plants are still present, suggesting that little change in environment had occurred from the top of the previous subzone.

From interval $375-275 \mathrm{~cm}$, fen plants, such as Carex aquatilis, $C$. diandra, a trigonous Carex-probably $C$. utriculata-Salix sp., Menyanthes trifoliata, and Epilobium glandulosum type, appear (fig. 17). Nuphar luteum ssp. polysepalum pollen and seeds, Potamogeton fruits, and Pediastrum still are present (figs. 15 and 17). These macrofossils suggest that a fen began to encroach into the pond. The pond was probably becoming very shallow and was surrounded by sedges, grasses, and other fen plants, perhaps growing on a floating mat. The aquatic macrofossils testify that a small pond was still present.

From $275 \mathrm{~cm}$ to the surface, macrofossils of truly aquatic plants, such as Nuphar, are absent (fig. 17). The Cyperaceae pollen curve is high except between 100 and $40 \mathrm{~cm}$ and represents chiefly fen species of Carex. The Cyperaceae curve ranges from 10 to 40 percent in the interval $260-175 \mathrm{~cm}$ (fig. 15). A small pollen peak at $260 \mathrm{~cm}$ is associated with many achenes of a trigonous Carex, probably $C$. utriculata or $C$. vesicaria (figs. 15 and 17). The abrupt disappearance of aquatic-plant macrofossils and the abundance of sedges imply that this interval represents the demise of the pond at this coring site.

In the interval $260-175 \mathrm{~cm}$, few Carex macrofossils are found, even though the Cyperaceae pollen curve reaches its maximum at $220 \mathrm{~cm}$ (figs. 15 and 17). Sphagnum moss leaves are very abundant in this interval, and the local sedges may have been choked out by this bog moss. The high Cyperaceae pollen values suggest that Carex was still abundant in other parts of the bog, however. Sphagnum warnstorfianum seems to be the most common Sphagnum in the park today, and the fossil leaves are morphologically similar to leaves of this species. Sphagnum liberates acids in its metabolic processes (Parihar, 1965); hence, it creates a rather acidic environment. It apparently grew along the margin of the pond, at least sporadically, throughout the earlier history of this site, and it was able to colonize the bog surface when the lake became overgrown. The most abundant Sphagnum interval coincides with the inferred cooler, moister period about 2,800 to 1,000 years B.P. (see following paragraphs and table 3 ), but its sporadic occurrence in the core could be controlled by local plant succession.

From interval 175-100 cm, Carex diandra, $C$. aquatilis, and the trigonous Carex are very abundant, and definite Carex utriculata and $C$. vesicaria (with perigynia) and $C$. limosa are sparsely present (fig. 17). Cyperaceae pollen values range from 10 to 17 percent (fig. 15). Sphagnum leaves disappear above $125 \mathrm{~cm}$, and Salix sp. leaves are present. These data suggest a change from an acid bog to a neutral or slightly alkaline fen. The community was similar if not identical to the Carex limosa-Carex diandra-Potentilla palustris community that now grows at the coring site.

In the interval 100-40 $\mathrm{cm}$, Cyperaceae pollen curves drop to less than 2 percent, and only fruits of the sedge Carex diandra are abundant (figs. 15 and 17). Several causes of this locally important change are possible. Recurring fires on the fen surface might 
have such an effect, but charcoal horizons that would record fire history are not present. The sedges apparently were not again choked by Sphagnum moss inasmuch as no leaves were found. A rising water level in the fen might explain all the changes. As the water level began to rise, Carex might have initially been favored over Sphagnum. As water levels continued to rise, the Carex too might die out locally and survive only on the margins of the basin. There is some support for this latter hypothesis. A few pollen grains (but no seeds) of the water lily Nuphar occur in this interval, whereas none occur in the adjacent sediments above or below (fig. 15). There also is a recurrence of the colonial alga Pediastrum at $80 \mathrm{~cm}$ (fig. 15). These plants are suggestive of higher water levels, but further evidence is needed to document this hydrologic change.

From a depth of $40 \mathrm{~cm}$ to the surface, Cyperaceae pollen percentages rise, and fruits of Carex diandra, the trigonous Carex, and Potentilla palustris are very abundant, at least in some horizons (figs. 15 and 17). Fruits of Carex utriculata, C. vesicaria, C. limosa, C. aquatilis, C. canescens, and Menyanthes trifoliata appear near the top. The present fen vegetation apparently became reestablished above the $40-\mathrm{cm}$ level. Slight changes in climate in this subzone are apparently marked by subtle shifts in pollen percentages. The recurrence of small amounts of Picea and Abies pollen, substantiated by macrofossils, suggests a cooler, moister climate during the last 5,000 years than in the 11,600 - to 5,000 -year interval. Two cooling pulses may be indicated by the spruce pollen curve here and at Cub Creek pond (Waddington and Wright, 1974): a mild one that apparently began about 5,000 years ago, and a stronger one that began about 2,800 years ago. Pollen and macrofossils of Pinus albicaulis, Pseudotsuga menziesii, and Pinus contorta that occur in the interval from 5,000 to 2,800 years ago suggest that climate was not as moist during that period as it was from 2,800 to the present, when these species were absent.

The Cyperaceae pollen maximum in the PiceaAbies-Pinus contorta subzone is demonstrably local, and it would seem logical to regard it as a successional phenomenon without any climatic significance. However, the Cyperaceae curve at Cub Creek pond (Waddington and Wright, 1970) is very similar in its form and its relationship with the increase in Picea and Abies. The apparently identical timing of local lake to fen succession at these two sites may be coincidental. But this succession may also have been triggered at all potential sites by cooler, moister conditions at the end of the Altithermal. Further pollen and plant macrofossil work in progress at sites near the 15-foot lagoon should help clarify this problem.

\section{DISCUSSION AND CONCLUSIONS}

Sediments in Buckbean fen record a vegetational succession beginning with the Betula subzone (of the Picea-Juniperus-Pinus albicaulis zone) about 12,000 14,500 years ago (table 3 ). The initial vegetation following deglaciations was probably open and tundralike with few if any trees, but subalpine as well as alpine plants were present. The climate was cold and moist, but it was probably comparable to that of nearby modern high subalpine or low alpine areas. This cold period is correlated with the late stages of the Pinedale Glaciation. The base of this zone is dated at $13,500 \pm 130$ years B.P. in Swan Lake Flat (sample WIS-432; Bender and others, 1971). A date of $13,140 \pm 700$ years B.P. (sample W - 2037; Sullivan and others, 1970) on plant material in silts about 7 miles northeast of Buckbean fen closely postdates retreat of middle Pinedale ice. Waddington and Wright (1974) recently obtained a date of $14,360 \pm 500$ years B.P. (sample W-2780) from the base of Cub Creek pond.

The Populus subzone marks the invasion of subalpine forest into the coring area. Treeline presumably migrated above the coring area up the slopes of the Two Ocean Plateau as the climate ameliorated. The forests were more open, but otherwise similar to the Picea-Abies-Pinus albicaulis forests in the park today. The climate was still cool and moist, probably much like that in the present subalpine vegetation association. This period probably postdates the last stages of melting of the middle Pinedale icecap.

The basal subzone of the Pinus contorta zone represents about the period $11,630-10,160$ years B.P. The Pinus contorta-Pinus albicaulis forest inferred from this subzone was different from any modern vegetation association. The two species at present overlap in their elevational distribution, but they do not grow together in extensive mixed forests in the park. Their joint occurrence suggests a slight lowering of vegetation associations, and a climate slightly cooler than at present. Both trees occur on drier sites, suggesting less precipitation than at present. This inferred cool, dry period postdates retreat of middle Pinedale glaciers, but its relationship to late Pinedale glacial advance is still uncertain.

A Pinus contorta forest much like the modern one was present during deposition of the middle subzone of the Pinus contorta zone, extending from about 
10,160 to 5,000 years ago. Picea and Abies, which now grow in suitable habitats at lake level, were apparently present only at higher elevations on the slopes of the Two Ocean Plateau at that time. Perhaps the gravelly soils near Buckbean fen accentuated the dry conditions and locally exterminated Picea and Abies. The climate was the warmest and driest of any inferred from the core, and this interval is correlated with the Altithermal period.

Radiocarbon dates of 9,240 and 5,390 years in the Pinus contorta subzone are separated by less than 1 metre of sediment (fig. 15), suggesting that a hiatus is present between 500 and $460 \mathrm{~cm}$. The dates seem reliable, but no break in the pollen diagram occurs in this interval. Macrofossils and sediment lithology suggest a change from a large open-lake environment to a small pond environment between 500 and $460 \mathrm{~cm}$, but this change could be explained without postulating a hiatus. A period of erosion or nondeposition probably occurred in this interval, but more evidence is needed to substantiate it. A smiliar hiatus occurred in the Chuska Mountains, N. Mex., during the Altithermal interval (Bent and Wright, 1963).

The distribution of Picea and Abies apparently expanded from the slopes of the Two Ocean Plateau down to lake level and they grew in mixed forests with Pinus contorta during the upper subzone of the Pinus contorta zone about 5,000 years ago. Proportions of Picea in these forests probably increased about 2,800 years ago during the climax of Neoglacial activity. Little change in the pollen spectra can be seen during the last 2,800 years. Picea does not now grow at the coring site (elev 7,750 ft), but it grows at the same elevation in many areas around the Southeast Arm of Yellowstone Lake (fig. 6). The pollen sequence supports Porter and Denton's (1967) suggestion that post-Altithermal cooling began about 5,000 years ago.

The pollen sequence at Cub Creek pond (Waddington and Wright, 1970, 1974) correlates well with that from Buckbean fen. The basal date of 14,360 B.P. at Cub Creek pond $(\mathrm{H}$. E. Wright, written commun., 1973) is about 1,000 years older than other dates on deglaciation in Yellowstone National Park. No sedimentological evidence shows contamination with older carbon, and the date is tentatively correlated with the base of Buckbean fen. Pollen curves in the two diagrams are remarkably similar, and they suggest that climatic changes triggered nearly synchronous changes in vegetation over large areas on the Yellowstone Plateau. The primary zonation in the diagrams is identical and a date of 11,630 years B.P. on the boundary between the two zones at Cub Creek pond corresponds well with the
Buckbean fen date of 11,550 years B.P. just above the boundary.

Zone 1 at Cub Creek pond contains relatively high percentages of Picea, Juniperus, Abies, Betula, Gramineae, and Artemisia pollen, and low values of Pinus. Most of the pine in this zone is Pinus albicaulis type. This assemblage suggests a pollen rain identical to that in my Picea-Juniperus-Pinus albicaulis zone. The Betula and Populus subzones cannot be recognized at Cub Creek pond (H. E. Wright, written commun., 1973).

Zone 2 at Cub Creek pond has very high Pinus (mainly $P$. contorta) pollen percentages, and low values of most other taxa as in my Pinus contorta zone. Other pollen diagrams from Yellowstone National Park which I have prepared (unpub. data) support the zonation of Buckbean fen.

Tentative correlation of pollen sequences of Buckbean fen with those from more distant areas is summarized in table 6 . Different vegetation, both past and present, in the other areas complicates correlation of vegetation changes, although direction of shifts may be related. The chart does show that the general climatic trend in all areas is from cold to cool to warm and back to cool again.

Further work is needed to resolve several problems that arose during this study. I have proposed that sediments representing part of Altithermal time are missing in Buckbean fen. Pollen and plant macrofossil work in progress from nearby lagoons, and appropriate $\mathrm{C}^{14}$ dates, may clarify the validity and nature of this period of erosion or nondeposition. Cores should be taken from other areas in the park to evaluate the areal extent of this hiatus.

More precise dating of high stands of Yellowstone Lake may also be possible with further paleobotanical work and $\mathrm{C}^{14}$ dating of cores related to each lake level, if sediments deposited during these stands are preserved in abandoned lagoons along the lake. Lagoons at the different levels all became open for lacustrine sedimentation when the lake was 110 feet above its present level, but lagoon isolation progressed from highest to lowest elevations as lake level fell. The horizon of isolation might be recognized in core sediments from lagoons formed by the lake at each of its major levels by a change in macrofossils of aquatic plants from deep- to shallow-water forms. By such a study the horizons could be dated by radiocarbon and the sequence worked out.

Many plant species from arctic tundra grow on peaks in the Rocky Mountains far south of their continuous arctic distribution. Modern alpine tundra in the park appears to have fewer species and 
TABLE 6.-Tentative correlation of pollen sequences

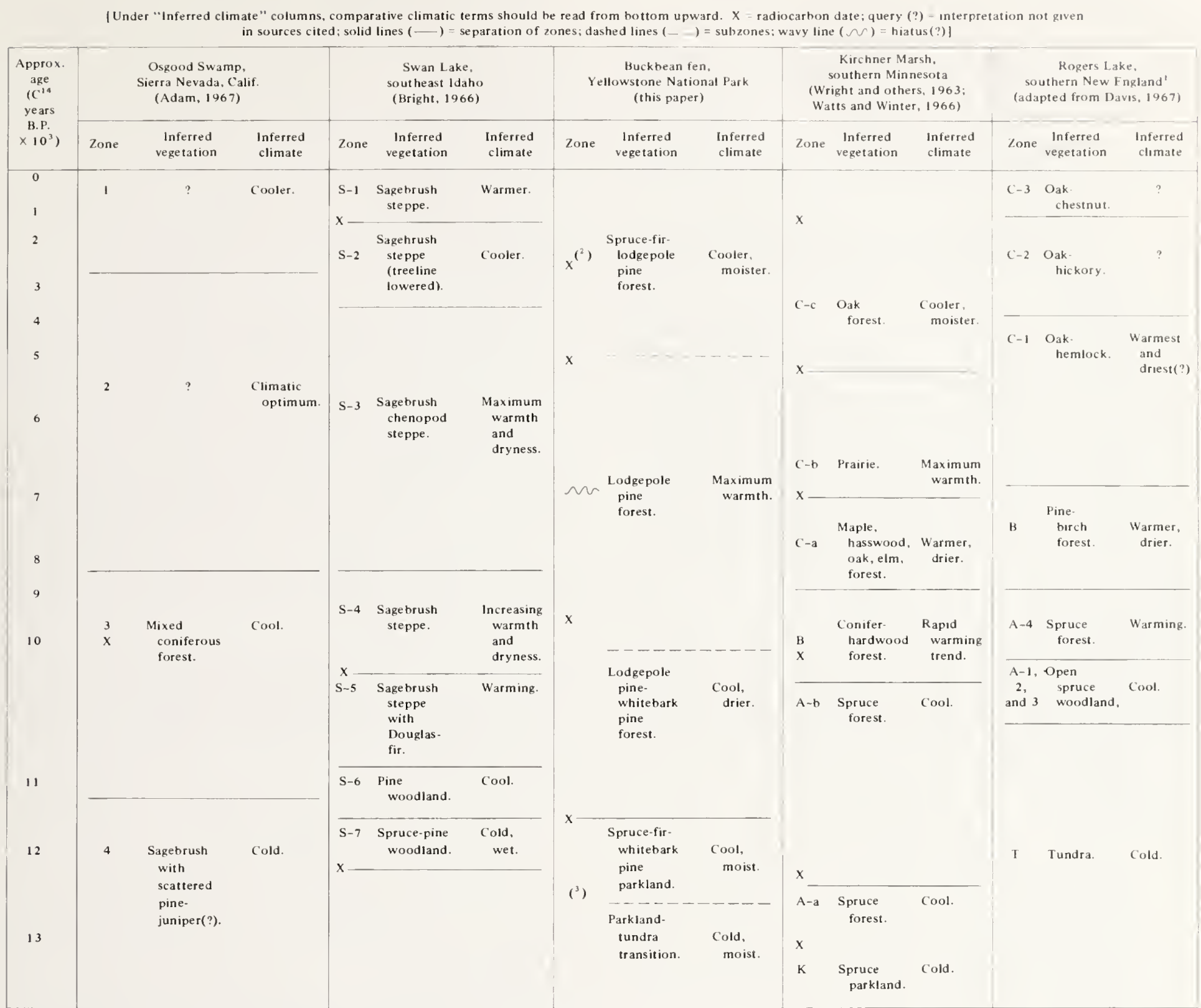

' Rogers Lake has 47 radiocarbon dates, on entire sediment column. Individual dates not shown.

${ }^{2}$ Pinus contorta.

${ }^{3}$ Picea-Juniperus-Pinus albicaulis.

community types than tundra of the Beartooth Plateau, Mont., to the north or that of the Wind River Range, Wyo., and the Front Range, Colo., to the south. The few late-glacial fossils of arctic-alpine plants from Lilypad pond indicate that these plants grew about 2,000 feet lower than they grow today. These fossils support the theory that during glacial periods, when treelines were lower, areas like the park may have been routes of southward migration for arctic species. When treelines rose in postglacial time, alpine species became isolated on high peaks and were eliminated in areas of lower elevation. Additional detailed pollen and plant-macrofossil studies are needed to determine areal and elevational distribution and composition of late-glacial tundra vegetation.

\section{REFERENCES CITED}

Adam, D. P., 1967, Late Pleistocene and Recent palynology in the central Sierra Nevada, California, in Quaternary paleoecology-Internat. Assoc. Quaternary Research, 7th Cong., 1965, Proc., v. 7: New Haven, Conn., Yale Univ. Press, p. $275-301$.

American Commission on Stratigraphic Nomenclature, 1961, Code of stratigraphic nomenclature: Am. Assoc. Petroleum Geologists Bull., v. 45, no. 5, p. $645-665$. 
Antevs, Ernst, 1955, Geologic-climatic dating in the West: Am. Antiquity, v. 20 , no. 4 , p. $317-335$.

Baker, F. S., 1944, Mountain climates of the western United States: Ecol. Mon., v. 14, p. 223 - 254.

Becker, C. F., and Alyea, J. D., 1964a, Temperature probabilities in Wyoming: Wyoming Univ. Agr. Expt. Sta. Bull. 415, 57 p. 1964b, Precipitation probabilities in Wyoming: Wyoming Univ. Agr. Expt. Sta. Bull. 416, 97 p.

Bender, M. M., Bryson, R. A., and Baerreis, D. A., 1971, University of Wisconsin radiocarbon dates IX: Radiocarbon, v. 13, no. 2 , p. $475-486$.

Bent, A. M., and Wright, H. E., Jr., 1963, Pollen analyses of surface materials and lake sediments from the Chuska Mountains, New Mexico: Geol. Soc. America Bull., v. 74, no. 4, p. $491-500$.

Birkeland, P. W., and Miller, C. D., 1973, Re-interpretation of the type Temple Lake moraine, and other Neoglacial deposits, southern Wind River Mountains, Wyoming: Geol. Soc. America Abs. with Programs, v. 5, no. 6, p. $465-466$.

Birkeland, P. W., Crandell, D. R., and Richmond, G. M., 1971, Status of correlation of Quaternary stratigraphic units in the western conterminous United States: Quaternary Research, v. 1 , no. 2 , p. $208-227$.

Bright, R. C., 1966, Pollen and seed stratigraphy of Swan Lake, southeastern Idaho-Its relation to regional vegetational history and to Lake Bonneville history: Idaho State Univ. Mus. Jour., Tebiwa, v. 9, no. 2, p. 1-47.

Choate, G. A., 1963, The forests of Wyoming: U.S. Forest Service Resource Bull. INT - 2, 46 p.

Critchfield, W. B., and Little, E. L., Jr., 1966, Geographic distribution of the pines of the world: U.S. Dept. Agriculture Misc. Pub. 991, 97 p.

Currey, D. R., 1974, Probable pre-Neoglacial age of the type Temple Lake moraine, Wyoming: Arctic and Alpine Research, v. 6 , no. 3 , p. $293-300$.

Daubenmire, R. F., 1943, Vegetation zonation in the Rocky Mountains: Bot. Rev., v. 9, p. $325-393$.

Davis, M. B., 1963, On the theory of pollen analysis: Am. Jour. Sci., v. 261 , no. 10 , p. $897-912$.

1965, A method for determination of absolute pollen frequency, in Kummel, Bernhard, and Raup, D. M., eds., Handbook of paleontological techniques: San Francisco, Calif., W. H. Freeman and Co., p. $674-686$.

1967, Pollen accumulation rates at Rogers Lake, Connecticut, during late- and post-glacial time: Rev. Palaeobotany and Paly nology, v. 2, nos. $1-4$, p. $219-230$.

Fletcher, E. H., 1927a, Climatic features of Yellowstone National Park: Sci. Monthly, v. 25, p. $329-336$.

$1927 \mathrm{~b}$, Annual meteorological summary with comparative data, 1927, Yellowstone Park, Wyoming: U.S. Dept. Agriculture, Salt Lake City, Utah, 8 p.

Fowells, H. A., compiler, 1965, Silvics of forest trees of the United States: U.S. Dept. Agriculture, Agriculture Handb. 271, 762 p.

Gill, L. S., 1957, Dwarf mistletoe of lodgepole pine: U.S. Dept. Agriculture, Forest Pest Leaflet 18, 7 p.

Hansen, H. P., 1948, Postglacial forests of the Glacier National Park region: Ecology, v. 29, p. 146-152.

1951, Pollen analysis of peat sections from near the Finley Site, Wyoming, in Moss, J. H., ed., Early Man in the Eden Valley [Wyoming]: Philadelphia, Pennsylvania Univ. Mus. Mon., p. $115-118$.

Harrington, H. D., 1954, Manual of the plants of Colorado: Denver, Colo., Sage Books, 666 p.

Hawksworth, F. G., and Wiens, Delbert, 1972, Biology and classifi- cation of dwarf mistletoes (Arceuthobium): U.S. Forest Service, Agriculture Handb. 401, 234 p.

Houston, D. B., 1973, Wildfires in northern Yellowstone National Park: Ecology, v. 54, no. 5, p. 1111-1117.

Jessen, Knud, 1955, Key to subfossil Potamogeton: Botanisk Tidsskr., v. 52, p. 1-7.

Johnson, P. L., and Billings, W. D., 1962, The alpine vegetation of the Beartooth Plateau in relation to cryopedogenic processes and patterns: Ecol. Mon., v. 32, p. 105-135.

Küchler, A. W., 1964, Potential natural vegetation of the conterminous United States: Am. Geog. Soc. Spec. Pub. 36, 116 p., map.

Lawrence, D. B., 1958, Glaciers and vegetation in southeastern Alaska: Am. Scientist, v. 46, no. 2, p. 89-122.

Levin, Betsy, Ives, P. C., Oman, C. L., and Rubin, Meyer, 1965, U.S. Geological Survey radiocarbon dates VIII: Radiocarbon, v. 7, p. $372-398$.

Lowery, A. R., [undated], Climatological summary of Yellowstone Park Station, 1930-1959-Cheyenne: U.S. Weather Bur., Climatography of the United States no. 20-48, 2 p.

1960, Climates of the States-Wyoming: U.S. Weather Bur., Climatography of the United States no. 60-48, 16 p.

McAndrews, J. H., 1967, Pollen analysis and vegetational history of the Itasca region, Minnesota, in Quaternary paleoecologyInternat. Assoc. Quaternary Research, 7th Cong., 1965, Proc., v. 7: New Haven, Conn., Yale Univ. Press, p. 219-236.

McDougall, W. B., and Baggley, H. A., 1956, Plants of Yellowstone National Park: Yellowstone Park, Wyo., Yellowstone Library Mus. Assoc., 186 p.

Maher, L. J., Jr., 1963, Pollen analyses of surface materials from the southern San Juan Mountains, Colorado: Geol. Soc. America Bull., v. 74, no. 12, p. $1485-1504$.

1972, Absolute pollen diagram of Redrock Lake, Boulder County, Colorado: Quaternary Research, v. 2, no. 4, p. $531-553$.

Marr, J. W., Clark, J. M., Osborn, W. S., and Paddock, M. W., 1968, Data on mountain environments III. Front Range, Colorado, four climax regions, 1959-1964: Colorado Univ. Studies, Ser. Biology, no. 29, 181 p.

Martin, A. C., and Barkley, W. D., 1961, Seed identification manual: Berkeley, California Univ. Press, 221 p.

Matsumura, Y., and Harrington, H. D., 1955, The true aquatic vascular plants of Colorado: Colorado Agr. Expt. Sta. Tech. Bull. 57, 130 p.

Miller, C. D., and Birkeland, P. W., 1974, Probable Pre-Neoglacial age of the type Temple Lake moraine, Wyoming-Discussions and additional relative-age data: Arctic and Alpine Research, v. 6 , no. 3 , p. $301-306$.

Parihar, N. S., 1965, An introduction to Embryophyta, Volume I, Bryophyta: Allahabad, Pakistan, Central Book Depot, 375 p.

Pennak, R. W., 1963, Ecological and radiocarbon correlations in some Colorado mountain lake and bog deposits: Ecology, v. 44, no. 1, p. $1-15$.

Porter, C. L., 1962-1968, A Flora of Wyoming, Parts 1-6: Wyoming Univ. Agr. Expt. Sta.

Porter, S. C., and Denton, G. H., 1967, Chronology of neoglaciation in the North American Cordillera: Am. Jour. Sci., v. 265, no. 3 , p. $177-210$.

Richmond, G. M., 1965, Glaciation of the Rocky Mountains, in Wright, H. E., Jr., and Frey, D. G., eds., The Quaternary of the United States: Princeton, N. J., Princeton Univ. Press, p. $217-230$.

1969a, Stagnation of the Pinedale icecap in the Yellowstone Lake Basin, Wyoming, in Abstracts for 1968: Geol. Soc. America Spec. Paper 121, p. 627. 
$1969 \mathrm{~b}$, Late Pinedale and Neoglacial glaciation in the Absaroka Range, east of Yellowstone Lake, Wyoming, in Abstracts for 1968: Geol. Soc. America Spec. Paper 121, p. $627-628$.

1969c, Development and stagnation of the last Pleistocene icecap in the Yellowstone Lake Basin, Yellowstone National Park, USA: Eiszeitalter u. Gegenwart, v. 20, p. 196-203.

1970a, Glacial history of the Yellowstone Lake Basin [abs.]: Am. Quaternary Assoc. Mtg., 1st, Yellowstone Park, Wyo., and Bozeman, Mont., 1970, Abs., p. 112 - 113.

$1970 \mathrm{~b}$, Comparison of the Quaternary stratigraphy of the Alps and Rocky Mountains: Quaternary Research, v. 1, p. $3-28$.

Richmond, G. M., and Pierce, K. L., 1968, Late Pleistocene center of ice-accumulation over Yellowstone Lake area, in Abstracts for 1967: Geol. Soc. America Spec. Paper 115, p. 441.

1972, Surficial geologic map of the Eagle Peak quadrangle, Yellowstone National Park and adjoining area, Wyoming: U.S. Geol. Survey Misc. Geol. Inv. Map I - 637 .

Ritchie, J. C., and de Vries, Bernard, 1964, Contributions to the Holocene paleoecology of westcentral Canada-A late-glacial deposit from the Missouri Coteau: Canadian Jour. Botany, v. 42 , no. 6 , p. $677-692$.

Stuchlik, Leon, 1967, Pollen morphology of the Polemoniaceae: Grana Palynologica, v. 7, p. $146-240$.

Sullivan, B. M., Spiker, Elliott, and Rubin, Meyer, 1970, U.S. Geological Survey radiocarbon dates XI: Radiocarbon, v. 12, p. $319-334$.

Tackle, David, 1961, Silvics of Lodgepole Pine: Intermtn. Forest and Range Expt. Sta. Misc. Pub. 19, 24 p.

Ting, W. S., 1966, Determination of Pinus species by pollen statistics: California Univ. Pubs. Geol. Sci., v. 58, 182 p.

U.S. Geological Survey, 1972, Surficial geologic map of
Yellowstone National Park: U.S. Geol. Survey Misc. Geol. Inv. Map I -710 .

Waddington, J. C. B., and Wright, H. E., Jr., 1970, LateQuaternary vegetational changes on the east side of Yellowstone Park, Wyoming [abs.]: Am. Quaternary Assoc. 1st Mtg., Yellowstone Park, Wyo., and Bozeman, Mont., 1970, Abs., p. $139-140$.

1974, Late Quaternary vegetational changes on the east side of Yellowstone Park, Wyoming: Quaternary Research, v. 4 , no. 2 , p. $175-184$.

Watts, W. A., and Winter, T. C., 1966, Plant macrofossils from Kirchner Marsh, Minnesota-A paleoecological study: Geol. Soc. America Bull., v. 77, no. 12, p. $1339-1360$.

Weber, W. A., 1967, Rocky Mountain Flora: Boulder, Colo., Colorado Univ. Press, $437 \mathrm{p}$.

Wilcox, R. E., 1965, Volcanic-ash chronology, in Wright, H. E., Jr., and Frey, D. G., eds., The Quaternary of the United States: Princeton, N.J., Princeton Univ. Press, p. $807-816$.

Wolfe, J. A., and Leopold, E. B., 1967, Tertiary and Early Quaternary vegetation of northeast Asia and northwest North America, in Hopkins, D. M., ed., The Bering Land Bridge: Stanford, Calif., Stanford Univ. Press, p. 193- 206.

Wright, H. E., Jr., Bent, A. M., Hansen, B. S., and Maher, L. J., Jr., 1973, Present and past vegetation of the Chuska Mountains, northwestern New Mexico: Geol. Soc. America Bull., v. 84 , no. 4 , p. $1155-1180$.

Wright, H. E., Jr., Livingstone, D. A., and Cushing, E. J., 1965, Coring devices for lake sediments, in Kummel, Bernhard, and Raup, D. M., eds., Handbook of paleontological techniques: San Francisco, Calif., W. H. Freeman and Co., p. $494-520$.

Wright, H. E., Jr., Winter, T. C., and Patten, H. L., 1963, Two pollen diagrams from southeastern Minnesota-Problems in the regional late-glacial and postglacial vegetational history: Geol. Soc. America Bull., v. 74, no. 11 p. $1371-1396$. 



\section{INDEX}

[Page numbers of major references are in italic]

A

Page

Abies

E17, 25, 26, 31, 38

$7,12,25,26,36$

lasiocarpa

Abies forest. Pinus contorta-Picea-

Abies lasiocarpa-Pinus albicaulis parkland,

$$
\text { Picea engelmannii- .... . . } \quad 25
$$

Abies parkland, Picea

Abies-Pinus albicaulis forests, Picea- . 4, 12 17, 18, 39

Abies-Pinus albicaulis park lands, Picea- . . 17, 18

Abies-Pinus albicaulis-Pinus contorta forest, Picea-

Abies Pinus contorto subzone, Picea-

38

Absaroka Range.

$5,10,12$

Abstract

Acer......

Aceraceae

Achille a lanulosa.

Aconitum columbianum

acutus, Scirpus

adenocaulon, Epilobium

Age, Altithermal

Bull Lake Glaciation

Gannett Peak Stade

Hypsithermal interval

Neoglaciation

Pinedale Glaciation

late stade....

middle stade

Post-Altithermal

Temple Lake Stade

Agropyron.

albicaulis, Pinus ..... 7, 12, 17, 25, 26, 34, 36, 37, 38 ;

pls. 1,5

Adler, thinlea

7,37 western

Algae

$A \ln u$

tenuifolia

$7,28,37 ;$ pl. 6

Alpine association

12,41

Alpine sorrel

Alpine tundra

9,36

alpinus, Potamogeton $\quad 10,14,17,25,30,32,36$; pl. 7

Altithermal period

$5,25,39,40$

Amaranthaceae

Ambrosia

$8,26,28,36 ;$ pl. 2

Amerceuthobium . .

amphibia, Persicaria

$9,14,17$

amphibium, Polygonum

$$
\text { pollen }
$$

Anemone, globose

Anemone multifida

$$
\text { globosa }
$$

angustifolia, Typha

angustifolium, Sparganium

Antennaria

aquatilis, Carex

Ranunculus

Arabis ...

$$
\text { glabra. }
$$

Arceuthobium

americanum

campylopodum

douglasii

Arctic-alpine plants, Lily pad pond

Arctic burreed

Aretic willow

8,28

$8,28,37$ arctica, Salix $\quad$ Page

Arctostaphylos uva-ursi

argenteus, Lupinus . .

Artemisia

$8,10,12$

$8,10,12$

tridentata

Artemisia pollen percentages

Artemisia steppe association pollen

Artemisia tridentata steppe, Gramineae

Ash

$8,26,31,32$

$8,10,16,17,19$

$10,13,17$

Aspen, quaking

Aster

Atriplex sp.

A ulacomnium palustre

Aulacomniaceae

Avens, large-leaf

B

Balsam poplar

balsamifera. Populus .._ 9, 25, 29,34, 35, 36; pl. 6

Basal zone

Bearberry

Beartooth Plateau, Mont.

Bechler River Ranger Station

Bedstraw, small

Betula.

glandulosa

occidentalis

Betula subzone

Betulaceae

biennis, Potentillo

Big sagebrush

Birch.

bog

$$
\text { river }
$$

Bistort

$$
\text { viviparous }
$$

Bistorta

bistortoides

vivipara.

bistortoides, Bistorta

Polygonum

Black cottonwood .

Bladderwort, common

$$
\text { small }
$$

blandowii, Helodium

Blue spruce. .

Blue willow . . . . . . . . . . . . . . . . . . . .

Bluebell. .

Blueberry, myrtle

Bluegrass .

Bluejoint grass

Bog birch

Boraginaceae

borealis, Glyceria

Broadleaf cattail .

Brome, smooth

Bromegrass

Bromus . .

$$
\text { inermis. }
$$$$
\text { sp. }
$$

Bryophyt

Bryophyte spore

Bryozoa

Buckbean fen basal zone dates.

Buffaloberry

$9,10,12$

8,15

8,10

7,15
7

9,15

8,28

8,31

9,12

9.12

$9,12,28$
Bull Lake Glaciation

Burreed .

Arctic

Bushy knotweed

Page

10.33

10

C

caespitosa, Deschampsia

$$
\text { Saxifraga }
$$

Calamagrostis canadensis inexpansa

Calamagrostis-Salix-Sedum rhodanthum
community

$$
\text { community }
$$

Callitrichaceae

Callitriche

Campanula rotundifolia

Campanulaceae

campylopodum, A rceuthobium

canadensis, Calamagrostis

Shepherdia

canescens, Carex

Caprifoliaceae

Carex

aquatilis

canescens

diandra

geyeri.

hoodii.

limosa.

petasta.

phaeocephala

rostrata

trigonous

utriculata

vesicaria

y, $19,27,33 ;$ pl. 3

Carex diandr

Carex fen

Carex. Gramineae meadow

Carex utriculata fen

Caryophyllaceae

Cattail, broadleaf

narrowleafed

Ceanothus velutinus

Ceratopyllaceae

Ceratophyllum demersum

Cercocarpus

Chara

Characeae

Cha rophytes

Cheno-Ams

Chenopodiaceae

Chenopodiaceae -Amaranthaceae

Chiming bells

Chrysothamnus

Cinquefoil

marsh.

Norway

shrubby

soft

Climacium dendroides

Climate

cooler moister

warmest.

Colorado blue spruce

columbianum, Aconitum

Common bladderwort

Common harebell

Common juniper

9.12,29, 33,

$9,15,30$

$9,15,30$ $8,28,31 ;$ pl. 8

8

8,17

8,10

8,28

$9,15,30$

$8,12,17$

$9,15,29,39 ;$ pl. 9

8,27

$17,29,37$

$9,14,17,29,38 ;$ pl. 9

$9,15,29,39$; pl. 9

$9,14,25,30,38$; pl. 9

9,12

9,10

$9,14,25,30,38$; pl. 7

9,15

9
38

$9,14,15,17,25,30,37,38$; pl. 7

$9,17,25,30,38$; pl. 7

14,17

17

14,17

8,27

10,33

10

$9,17,27$

8,37

9,26

7

30,31

$8,16,32$

$8,16,26$ 


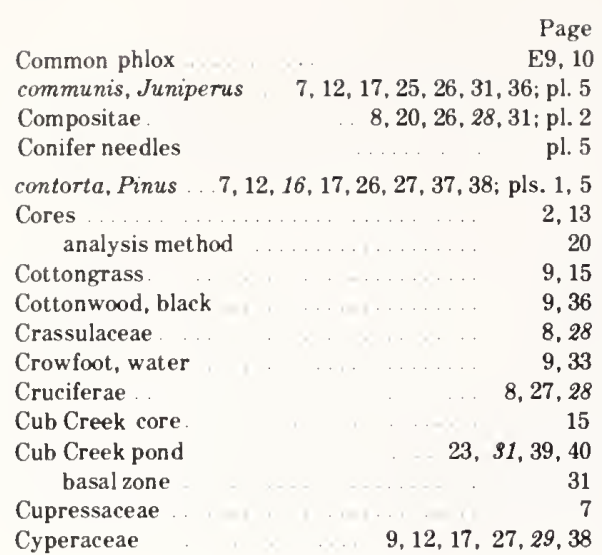

$\mathrm{D}$

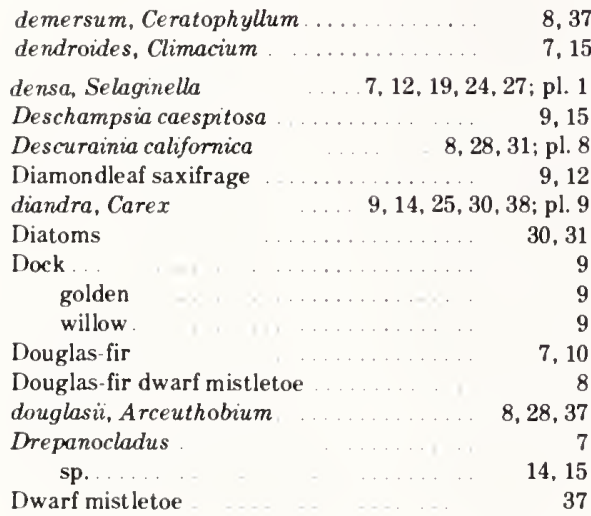

Eleagnaceae

\begin{tabular}{|c|c|c|}
\hline \\
\hline echya & &, $30 ; \mathrm{F}$ \\
\hline Elephant & & \\
\hline Elymus & & 9,10 \\
\hline s, Phyllodoce & & \\
\hline ruce & & \\
\hline nge & $7,12,16,25$ & $36 ; \mathrm{pl}$ \\
\hline Ephed & & \\
\hline & & $26 ; \mathrm{p}$ \\
\hline Ephedr & & \\
\hline Epilobiu & & $8 ; \mathrm{p}$ \\
\hline gland & & $38 ; p$ \\
\hline lact & 8 , &, 36 \\
\hline Equi & & \\
\hline Equi & & \\
\hline Eric & & \\
\hline Eric & & \\
\hline Eriop & & \\
\hline subalpinum & & \\
\hline sp. & $\ldots \ldots$ & \\
\hline
\end{tabular}

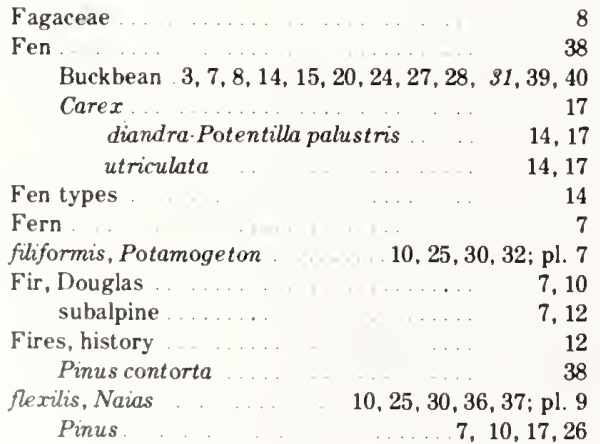

floribunda, Pentaphylloides $\quad \mathrm{E9}, 15,17$

Page

Forest, fires

open, mixed.

34

Picea-A bies-Pinus albicaulis $\quad$ 4, 12, 17, 18, 39 Picea-Abies-Pinus albicaulis-Pinus
contorta

17

Pinus albicaulis-Pinus contorta

Pinus contorta

$4,12,17,18,25,37,39$ closed open

Pinus contorta-Picea-Abies

Pinus contorta-Pinus albicaulis .

Populus tremulondes-Pseudotsuga

Pseudotsuga

Fragaria

Franseria

Fraxinus

Front Range, Colo.

fruticosa, Potentilla

fueginus, Rumex

maritimus

Further work

$9,29,37$; pl. 6

Further work

G

Galium trifidum

$9,14,15$

Gannett Peak end moraines

$5,25,38$

Gannett Peak Stade

Gentian, Rocky Mountain fringed

Gentiana thermalis

$5,25,38$

Gentianaceae

Gentianopsis thermalis

Geum macrophyllum

geyeri, Carex

glabra, Arabis

Glacial history

Glacier Peak

glandulosa, Betula

glandulosum, Epilobium

$$
\text { Ledum }
$$

globosa, Anemone multifida

Globose anemone

Glyceria borealis

grandis

maxima grandis

Golden dock

gracilis, Potentilla

Graminea

Gramineae-Artemisia tridentata steppe...

Gramineae meadow, Carex.

Gramineae/Pinus ratio

gramineus, Potamogeton

grandis, Glyceria

Glyceria maxima

Grass, blue-

bluejoint-

Brome-

large manna

needle-

northern manna-

northern reed.

smooth brome

squirrel-tail

tufted hair-

wheat-

wild-rye

Grass family

Greasewood

Green joint fir

Greenmilfoil

groenlandica, Pedicularis

Grouse Creek

$8,25,28,31,33,36$; pl. 6

$8,28,38 ;$ pl. 8

8,17
9

9,15

9,30

10

$10,30,37 ;$ pl. 9

9, 20,31, 36; pl. 8

$9,12,17,20,27,30,31$

17

37

$20,34,36,37$
$25,30,37 ;$ pl. 7

$10,25,30,37$; pl. 7

$10,30,37$; pl 9

10

9,15

9,10

10,37

10

9
9,15

9,15
9

10

9,15

9,10

9

12

$8,10,16$

7

8

9,15

5

Haloragaceae

Harebell, common

Helodium blandowii

Hemlock, mountain

$H$
9,15

8,28

8,10

7,15
Hemlock-Continued western

heterophylla, Tsuga.

Honeysuckle family

hoodii, Carex

Hornwort.

Horsetail

Hydrodictyaceae

Hydrophyllaceae

Hypnaceae.

Hypsithermal interval

hystrix, Sitanion

\section{I, J}

illinoensis, Potamogeton

inermis, Bromus

9,10

inexpansa, Calamagrostis

integrifolium, Sedum rosea

$9,15,30$

Isoëtaceae

Isoëtes

islandica, Koenigia

Rorippa

7,17

9,$36 ;$ pl. 3

Jacobs ladder

Jointfir, green

Juglandaceae

Juglans

Juncaceae

Juniper, common Rocky Mountain

Juniperus

communis

virginiana scopulorum

$7,26,31 ; \mathrm{pl} .1$

$6,31,36 ;$ pl. 5

unerus Pinus albicaulis zone, Picea-... $10,17,26$

9,12
Kame deposits

Kings Crown

Kinnikinnik

Knotweed, bushy

Koenigia

islandica

actiflorum, Epilobium

Ladysthumb

Lamar Ranger Station

lanceolatum, Sedum

lanulosa, Achillea

Large-leaf avens

mannagrass

Larix lyallii occidentalis

lasiocarpa, Abies

latifolia, Typha

Ledum glandulosum

Leguminosae

Lentibulariaceae

Leskeaceae

Liguliflorae, subfamily

ligulifolia, Salix

Lily, yellow pond

Lily pad pond basal zone

dates

Limber pine

limosa, Carex

Lodgepole pine

Lodgepole pine dwarf mistleto

longifolium, Sitanion

Loranthaceae

Lupine, silvery

Lupinus argenteus

luteum polysepalum. Nuphar

K, L

Luzula parviflora

$$
\text { spicata }
$$

lyalli, Larix
8,17

9, 36; pl. 3

$8,28,36 ;$ pl. 8

$8,26,28,3$

$9,14,15$

$3,15,20,28,31,41$
$9,14,25,30,38$; pl. 7 


\begin{tabular}{|c|c|}
\hline \multicolumn{2}{|l|}{ 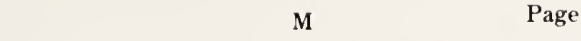 } \\
\hline Macrofossils, identification & 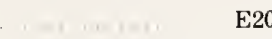 \\
\hline macrophyllum, Geum & 9,15 \\
\hline macrostachya, Eleocharis. & $9,17,30 ;$ pl. 9 \\
\hline maculata, Persicara.. & \\
\hline Mahogany, mountain & .. \\
\hline Mammoth & 10 \\
\hline climate & \\
\hline Mannagrass, large & 10,37 \\
\hline northern & \\
\hline Maple. & \\
\hline maritimus fueginus, Rumex & \\
\hline Marsh cinquefoil & 9,14 \\
\hline Marsheress & 8,36 \\
\hline Matted saxifrage & 9,12 \\
\hline maxima grandis, Glyceria. & $10,30,37$; pl. 9 \\
\hline Meadow, Carex-Gramineae & $\ldots .$. \\
\hline Meadow rue & \\
\hline Melosira. & 30 \\
\hline Menyanthaceae & 8,28 \\
\hline Menyanthes & 27 ; pl. 3 \\
\hline trifoliata & $8,14,15,25,28,38 ;$ pl. 6 \\
\hline menzieii, Pseudotsuga & $7,10,24,25,37,38 ;$ pl. 5 \\
\hline Mertensia & 8,12 \\
\hline mertensiana, Tsuga & 7. 27; pl. 1 \\
\hline Middle Pinedale glaciers & 39 \\
\hline Mimulus. & $9 ;$ pl. 2 \\
\hline minimum, Sparganium & 10,30 \\
\hline minor, Utricularia & 8,14 \\
\hline Mistletoe, Douglas-fir dwarf & 8 \\
\hline$d w \operatorname{arf}$ & 37 \\
\hline lodgepole pine dwarf & 8,37 \\
\hline western dwarf & 8 \\
\hline Monkey flower .. & 9 \\
\hline Monkshood & 9,12 \\
\hline Mosses & 7,17 \\
\hline Mount Evans fire & 34 \\
\hline Mountain hemlock & 7 \\
\hline Mountain mahogany & 9 \\
\hline Mountainheath . & 8 \\
\hline multiflora, Phlox & 9,10 \\
\hline multifida globosa, Anemone & \\
\hline Myriophyllum & $8,17,27,37 ;$ pl. 2 \\
\hline sprcatum exalbescens & 8,28 \\
\hline verticillatum & 8,28 \\
\hline & 25,37 \\
\hline myrtillus, Vaccinium & 8,12 \\
\hline Myrtle blueberry .. & 8,12 \\
\hline
\end{tabular}

$\mathrm{N}$

Naiad

10,36

Naiadaceae

Naias flexilis

Narrowleafed cattail

Needle, conifer

Needle' distribution

Needlegrass

negundo, Acer

Neoglaciation

Nettle

Northern mannagrass

Northern pondweed

Northern reedgrass

norvegica, Pontentilla

Norway cinquefoil

Nuphar

luteum polysepalum

Nuphar-Potamogeton type Nymphaeaceae

$0, \mathrm{P}$

Oak

occidentalis, Betula

Oleaceae

Onagraceae

Oxyria

10,14

9,15

9. 29

17, 27, 37; pl. 2

$8,14,25,28,37$

38; pl. 7

14
8,28

$8,27,28$

$9,27,28,36 ;$ pl. 4
Pale willow herb $\quad$ Page

palustre, Aulacomnium arklands Picea-Abies Pinus albicaulis.

$14,25,27,29,30 ;$ pls. 4,8

Picea engelmannii-Abies lasiocarpa. Pinus albicaulis

Pinus albicaulis-Picea

parviflora, Luzule

paucifolius, Rumex

pectinatus, Potamogeton

Pediastrum

Pediastrum colonies

Pedicularis

groenlandica

Pentaphylloides floribunda

\begin{tabular}{rr}
17 \\
\hdashline$\quad 10,12,15$ \\
9
\end{tabular}

Persicara maculata

Persicaria amphibu

persicaria, Polygonum

$7,27,31,38,39, \mathrm{pl}, 4$

Phacelia

phaeocephala,Carex

Phlox, common....

Phlox multiflora

Phyllodoce empetriformis

Picea. . . .

engelmann pungens

$17,25,26,31,34,38 ; \mathrm{pl} .1$

$7,12,16,25,26,36$; pl. 5

Picea-Abies forest, Pinus contorta

Picea-Abies parkland

Picea-Abies-Pinus albicaulis forests . . . 4, 12, 17, 39 pollen

Picea-Abies- Pinus albicaulis parklands

Picea-Abies-Pinus albicaulis-Pinus contorta forest

Picea-Abies-Pinus contorta subzone

Picea engelmannii-Abies lasiocarpa-Pinus albicaulis parkland

Picea-Juniperus-Pinus albicaulis zone

Picea parkland, Pinus albicaulis.

Picea/ Pinus ratio

Pinaceae

Pine, limber

lodgepole

ponderosa

whitebark

Pinedale Glaciation

Pinus albicaulis

$4,5,25,31,35,37,39$

$7,12,17,25,26,34,36,37$.

Pinus albicaulis forest, Pinus contortaPinus albicaulis forests. Picea-Abies- 4, 12, 17, 18, 39

Pinus albicaulis parklands, Picea-Abies- ... 17, 18

Picea engelmannii-Abies lasiocarpa- $\quad 25$

Pinus albicaulis-Picea parkland

Pinus albicaulis-Pinus contorta forest ..... 25 Picea-Abies

Pinus albicaulis/Pinus contorta ratio 20,31,34, 36,

$\begin{array}{ll}\text { Pinus albicaulis zone, Picea-Juniperus- . . . } & 37,38 \\ & 30,39\end{array}$

Pinus contorta ‥ 7, 12, 16, 17, 26, 27, 37, 38; pls. 1,5

Pinus contorta forests $\quad 4,12,17,25,39$ pollen

Picea-Abies-Pinus albicaulis

torest

Pinus contorta-Pinus albicaulis forest

Pinus contorta-Pinus albricaulis subzone

Pinus contorta subzone

hiatus

Picea-Abies

Pinus contorta zone

Pinus flexilis

ponderosa

Pinus pollen curve

Plantago

Plantain

Plataginaceae

Polemoniaceae

Polemonium
7,15
$., 4,8$

25

10,30

30
9,27

9,15

$9,15,17$

$9,14,17$

$9,27,28$

8,10

9,15

9,10

9,10

8,17

7,16

17,18

25,98

25

$25, \$ 0,39$

17
20

20
7,24

7,10

7,12

7,10

7,12

38 ; pls. 1,5

17

Pollen, analysis method

Artemisia steppe

Picea-Abies-Pinus albicaulis forests

Picea-Abies-Pinus albicaulis parklands

Pinus contorta forests

Pseudotsuga forest

Pollen curves

Pollen indentification

Pollen rain

Pollen ratios

Pollen samples, other

Polygonaceae

Polygonum

amphibium

bistortoides .

persicaria

ramosissimum

viviparum

Polypodiaceae

polysepalum, Nuphar luteum

Page

F16

16
18

18

18

Pond, warm water

$8,14,25,28,37$,

38 ; pl. 7

Ponderosa pine

ponderosa, Pinus

7,10

Pondweed

$$
\text { northern }
$$

sago

7. 10

10,14

Poplar, balsam

Populus

balsamifera

tremuloides

trichocarpa

10

9,34

$9,26,34$; pl. 4

Populus subzone

Populus tremuloides-Pseudotsuga forest

Post-Altithermal cooling

Potamogeton.

alpinus

filiformis

gramineus

$10,14,17,25,30,32,36,31$

illinoensis

pectinatus

vaginatus

sp.

Potentilla biennis

fruticosa.

gracilis

norvegica

palustris

sp.

Quaternary palynology

36 ; pl. 6

$9,10,12$

$9,29.36$

$25,35,39$

17

$17,27,38$

$10,25,30,32$; pl. 7

$10,25,30,37$; pl. 7

10,30

10,30

10,30

$9,29,36$; pl. 8

$9,20,31,36$; pl. 8

9,29

. $14,25,27,29,30$, pls. 4 , 8

12,33

procumbens. Sibbaldia

14,17

Pseudotsuga

menziesii

$9,29,33$

Pseudotsuga association

$25,26,37$; pl.

Pseudotsuga forest, Populus tremuloides- .

pungens, Picea

7,16

Pussytoes

8,10

Q, R

Quaking aspen

$9,10,12$

Quercus

Quillwort

Rabbitbrush

Ragweed

ramosissimum, Polygonum

Ranunculaceae

Ranunculus

aquatilis.

Ratio, Gramineae/Pinus

Picea/Pinus

Pinus albicaulis/Pinus contorta

7,10
22

9,27

edcedar

Reedgrass, northern

References cited

Rhamnaceae

Rhizopods

rhodanthum, Sedum 


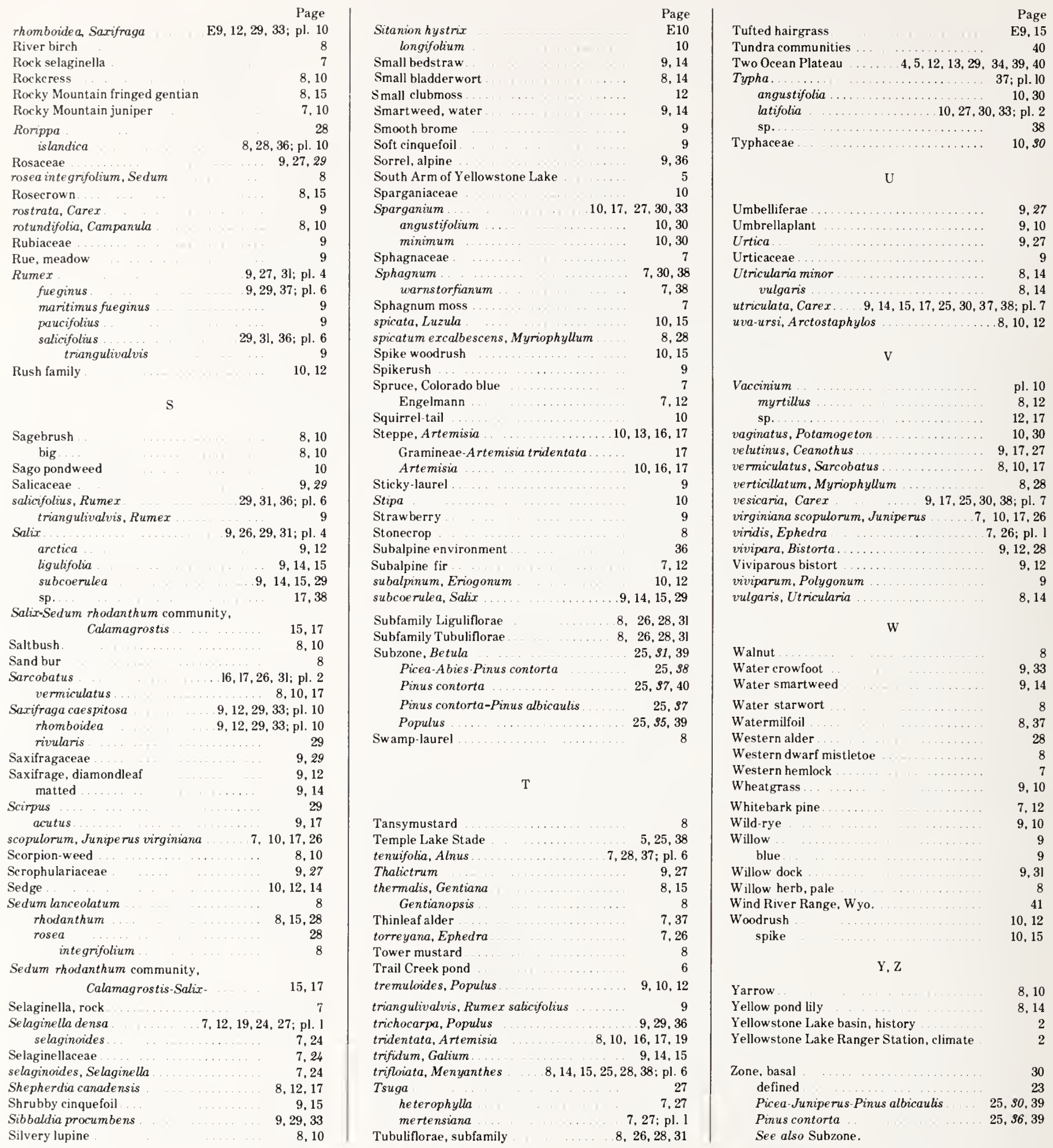




\section{PLATES $1-10$}

Contact photographs of the plates in this report are available, at cost, from the U.S. Geological Survey Photographic Library, Box 25046 Federal Center, Denver, Colorado 80225. 


\section{PLATE 1}

Fossil spores and pollen from Buckbean fen core $\times 535$.

Figure 1. Bryophyte spore; $890-\mathrm{cm}$ depth.

1a. Midfocus.

1b. High focus.

2. Ephedra viridis type pollen; $340-\mathrm{cm}$ depth.

$2 a$. High focus.

$2 b$. Midfocus.

3. Picea pollen; $850-\mathrm{cm}$ depth.

4. Pinus contorta type pollen; $160-\mathrm{cm}$ depth.

5. Pinus albicaulis type pollen; $920-\mathrm{cm}$ depth.

$5 a$. High focus.

$5 b$. Slightly lower focus.

6. Pseudotsuga pollen; $700-\mathrm{cm}$ depth.

7. Selaginella densa spore; $920-\mathrm{cm}$ depth.

8. Juniperus pollen; $890-\mathrm{cm}$ depth.

9. Tsuga mertensiana; 240-cm depth.

9a. Midfocus.

$9 b$ High focus. 

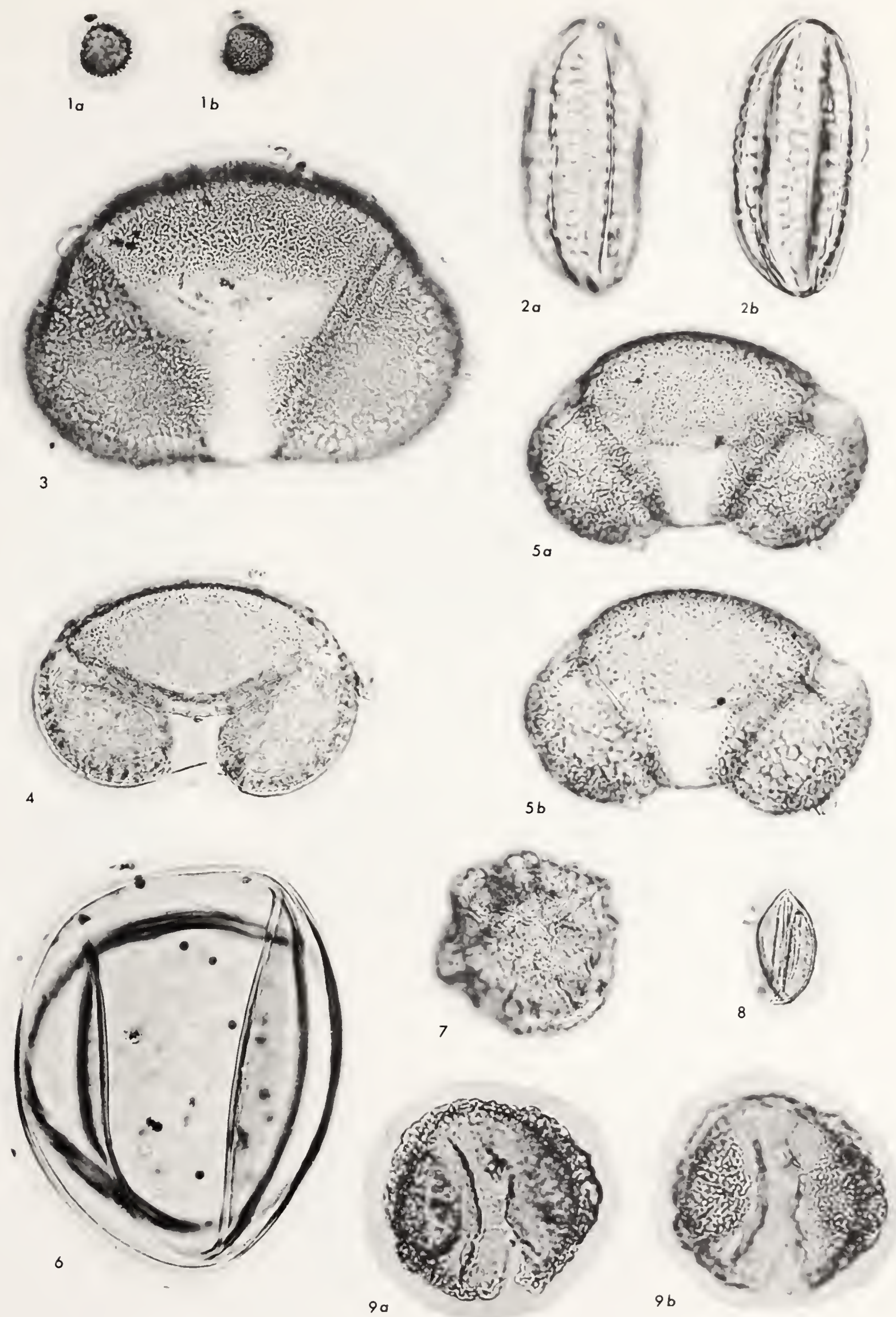

BRYOPHYTE, EPHEDRA, PICEA, PINUS, PSEUDOTSUGA, SELAGINELLA, JUNIPERUS, AND TSUGA 


\section{PLATE 2}

Fossil pollen from Buckbean fen core. $\times 1,054$.

FigURE 1. Nuphar; $340-\mathrm{cm}$ depth.

2. Typha latifolia tetrad; $943-\mathrm{cm}$ depth.

3. Sarcobatus; 700-cm depth.

$3 a$. High focus.

$3 b$. Slightly lower focus.

4. Compositae, subfamily Liguliflorae; $920-\mathrm{cm}$ depth.

4a. High focus.

4b. Midfocus.

5. Ambrosia; 850-cm depth.

6. Myriophyllum; 440-cm depth.

$6 a$, High focus, to $6 c$, midfocus.

7. Arceuthobium; $700-\mathrm{cm}$ depth.

$7 a$. High Focus.

7b. Midfocus.

8. cf. Mimulus; $160-\mathrm{cm}$ depth.

$8 a$. High focus.

$8 b$. Midfocus. 

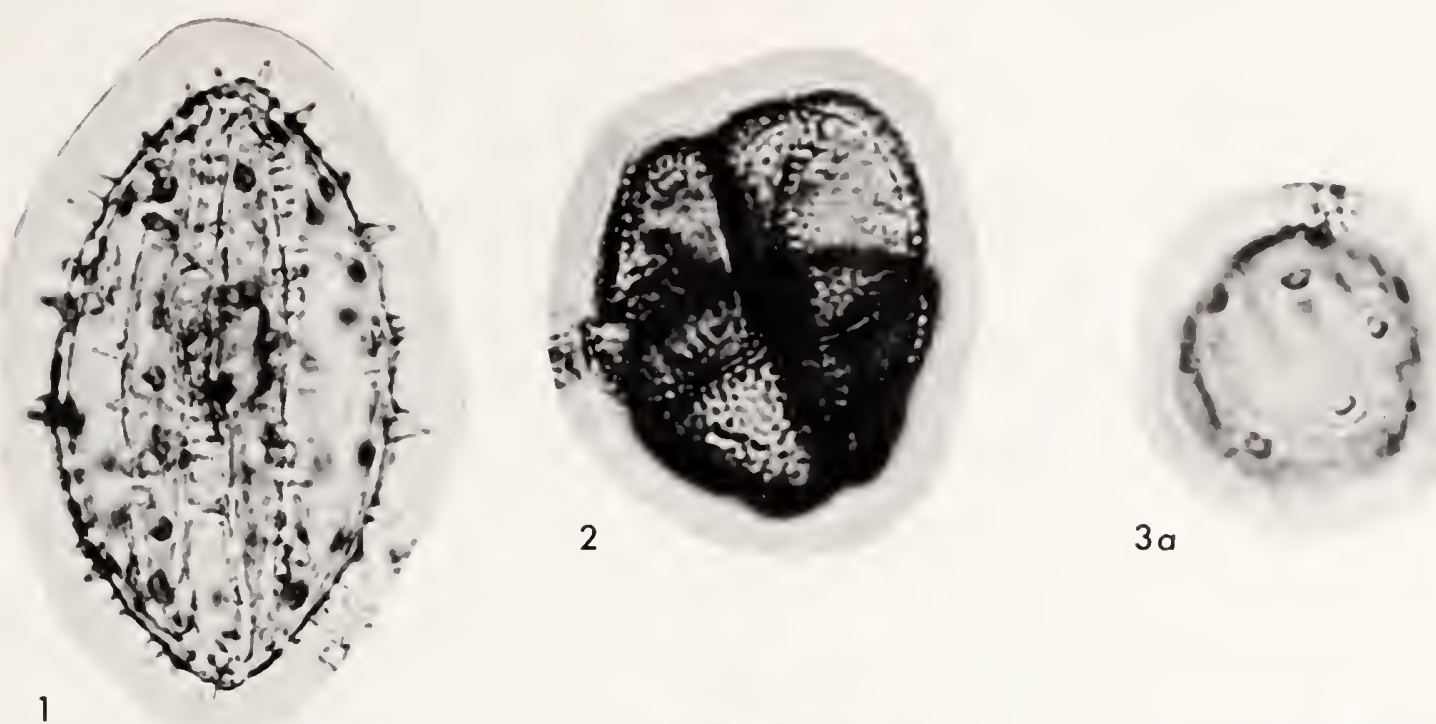

$3 a$

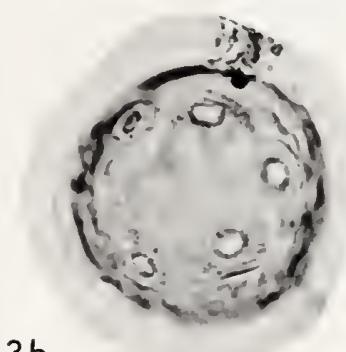

$3 b$
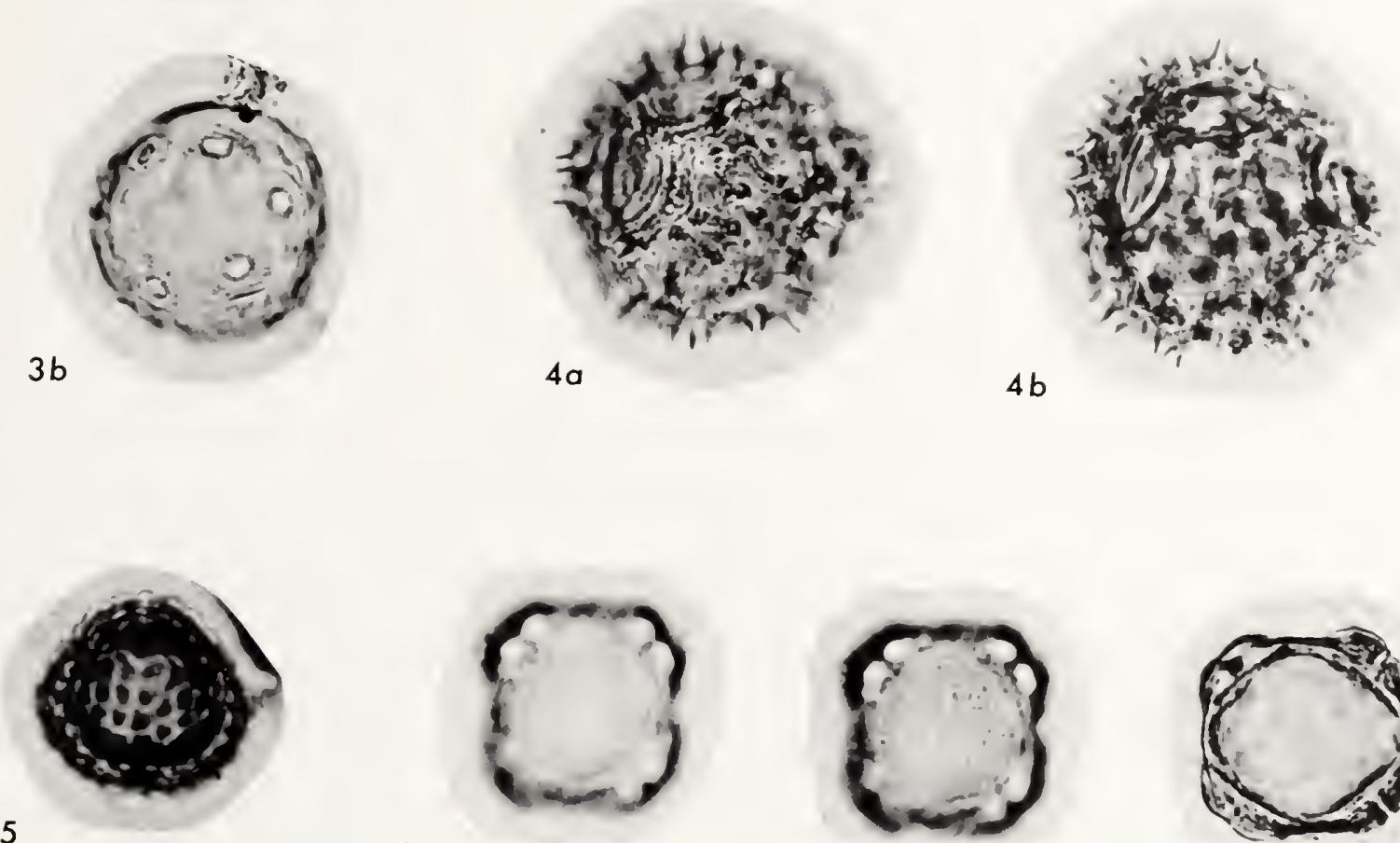

$6 a$

$6 b$
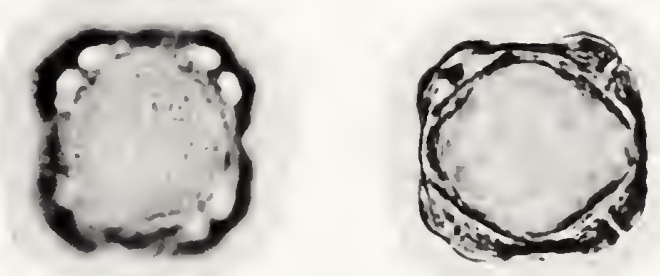

$6 c$

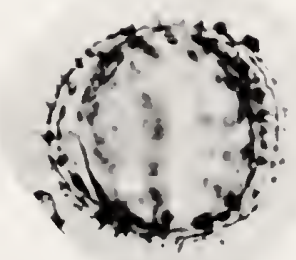

$7 a$

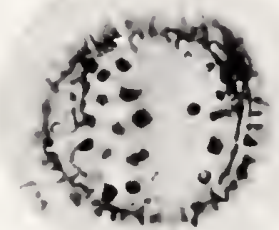

$7 b$

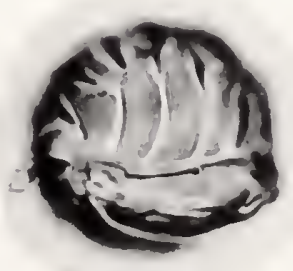

$8 b$

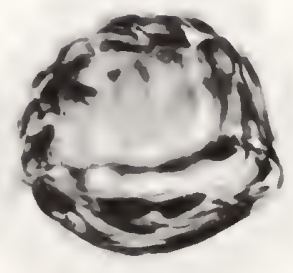

NUPHAR, TYPHA, SARCOBATUS, COMPOSITAE, AMBROSIA, MYRIOPHYLLUM, ARCEUTHOBIUM, AND MIMULUS 


\section{PLATE 3}

Fossil pollen from Buckbean fen core. $\times 1,054$.

Figure 1. Menyanthes; $60-\mathrm{cm}$ depth.

$1 a$, High focus, to $1 d$, low focus.

2. Polemonium; 842-cm depth.

$2 a$, High focus, to $2 c$, midfocus.

3. Bistorta; $900-\mathrm{cm}$ depth.

$3 a$, High focus, to $3 c$, midfocus.

4. Koenigia islandica; $850-\mathrm{cm}$ depth.

$4 a$. High focus, to $4 d$, midfocus. 


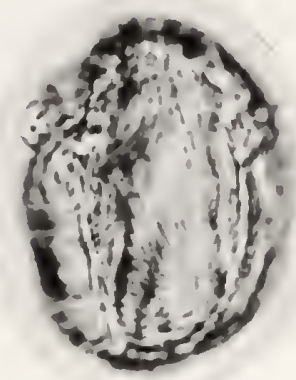

la

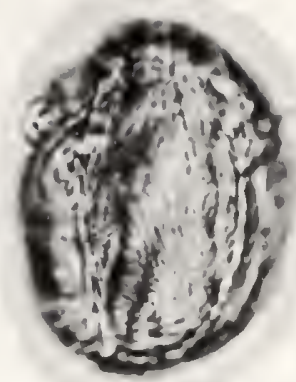

16

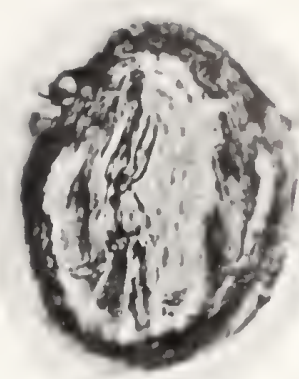

$1 c$

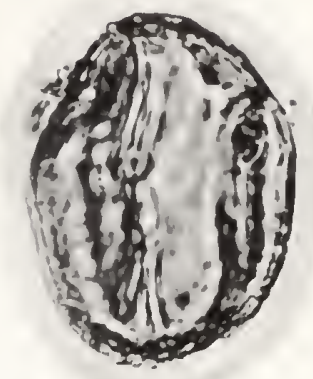

$1 d$
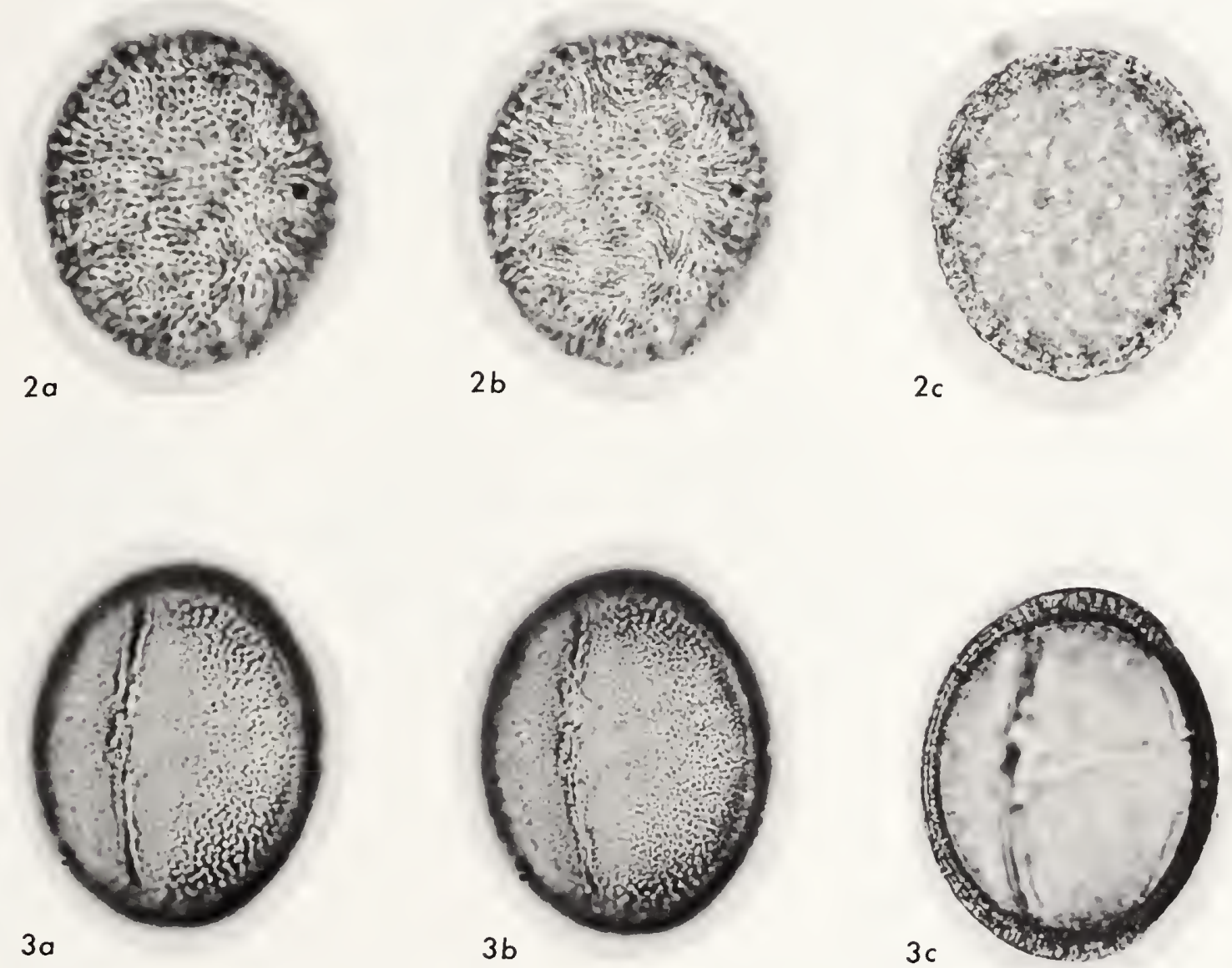

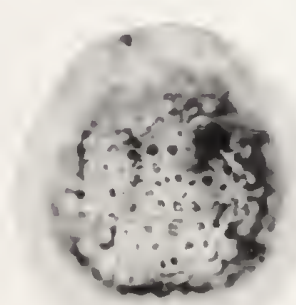

$4 a$

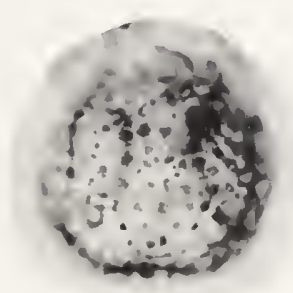

$4 b$

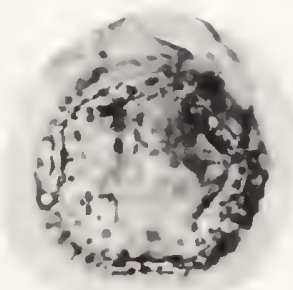

$4 c$

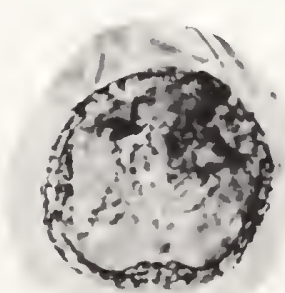

$4 d$

MENYANTHES, POLEMONIUM, BISTORTA, AND KOENIGIA 


\section{PLATE 4}

Fossil pollen and alga from Buckbean fen core. $\times 1,054$.

Figure 1. Oxyria type pollen; 850 -cm depth.

$1 a$. High focus, to $1 e$, midfocus.

2. Rumex pollen; 920 -cm depth.

$2 a$. High focus, to $2 c$, midfocus.

3. Potentilla palustris pollen; 0 -cm depth.

3a. Equatorial view.

$3 b$. Polar view.

4. Populus pollen; 842-cm depth.

$4 a$. High focus.

$4 b$. Slightly lower focus.

5. Salix pollen; $900-\mathrm{cm}$ depth.

$5 a$, High focus, to $5 c$, midfocus.

6. Pediastrum, a green alga; $920-\mathrm{cm}$ depth. 


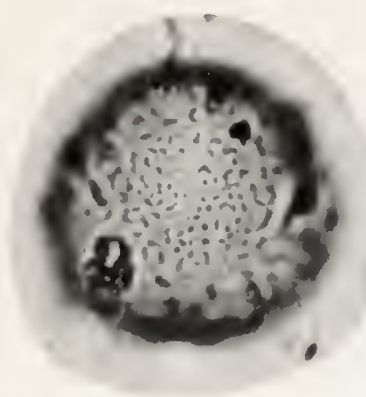

la

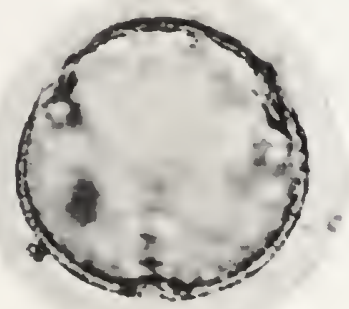

le

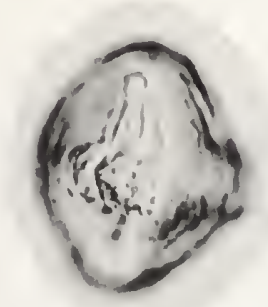

$3 a$

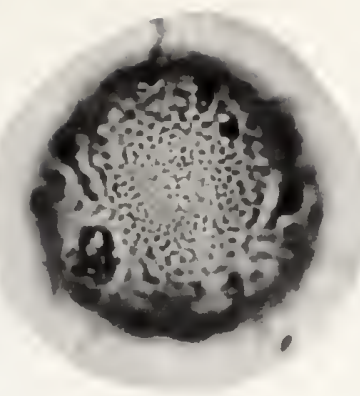

16

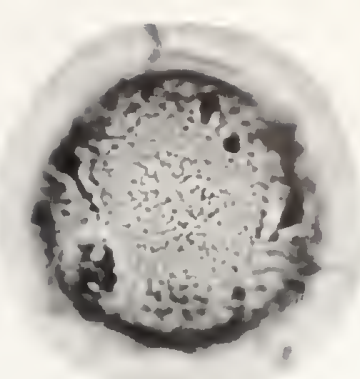

Ic

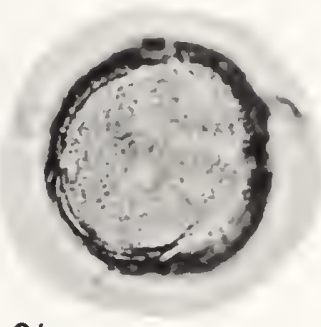

$2 b$

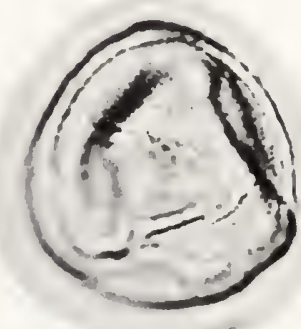

$4 a$

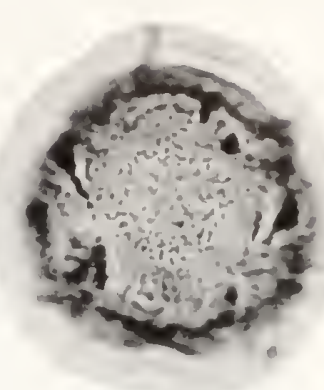

Id

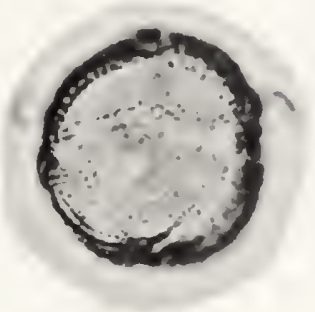

$2 a$

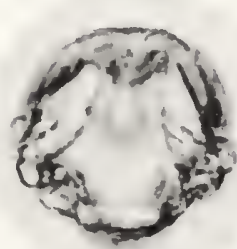

$3 b$

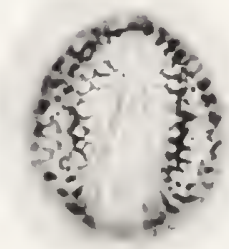

$5 b$
$5 c$

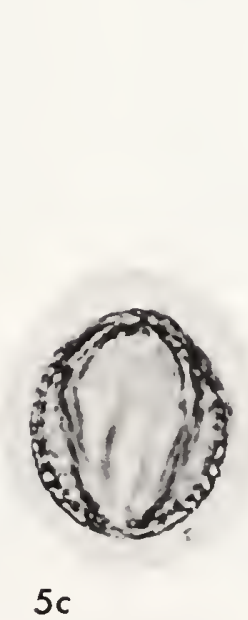

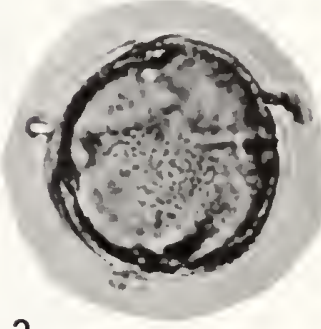

$2 c$

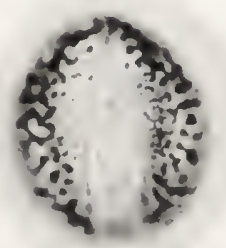

$5 a$

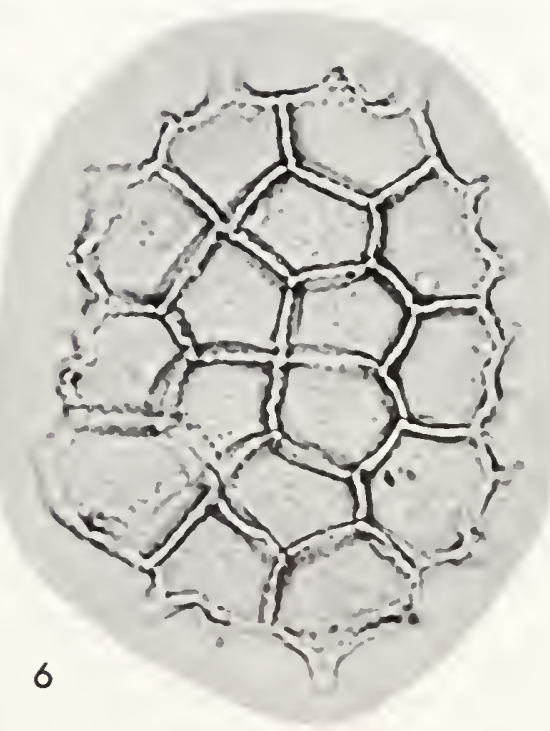

OXYRIA, RUMEX, POTENTILLA, POPULUS, SALIX, AND PEDIASTRUM 


\section{PLATE 5}

Fossil and modern conifer needles. $\times 11$.

FigurF, 1-3. Juniperus communis.

1. Fossil needle tip; Buckbean fen core, 820 - to $825-\mathrm{cm}$ depth.

2. Fossil needle (near base); Buckbean fen core; $825-$ to $830-\mathrm{cm}$ depth.

3. Modern needle; RGB - 199.

4, 5. Picea engelmannii.

$4 a$, Fossil needle, and $4 b$, cross section; Lilypad pond core, 930 - to $935-\mathrm{cm}$ depth.

$5 a$, and $5 b$, Modern needle, and $5 c$, cross section; COLO 180762 .

6, 7. Pinus albicaulis.

$6 a$, Fossil needle, and $6 b$, cross section; Buckbean fen core, $360-$ to $365-\mathrm{cm}$ depth.

$7 a$, Miodern needle, and $7 b$, cross section; R. G. Baker collection.

8, 9. Pinus contorta.

$8 a$, Fossil needle, and $8 b$, cross section; Buckbean fen core, 360 - to $365-\mathrm{cm}$ depth.

$9 a$, Modern needle, and $9 b$, cross section; R. G. Baker collection.

10, 11. Pseudotsuga menziesii.

$10 a$, Fossil needle, and 10b, cross section; Buckbean fen core, 350- to 355-cm depth.

$11 a$, Modern needle, and $11 b$, cross section; R. G. Baker collection. 

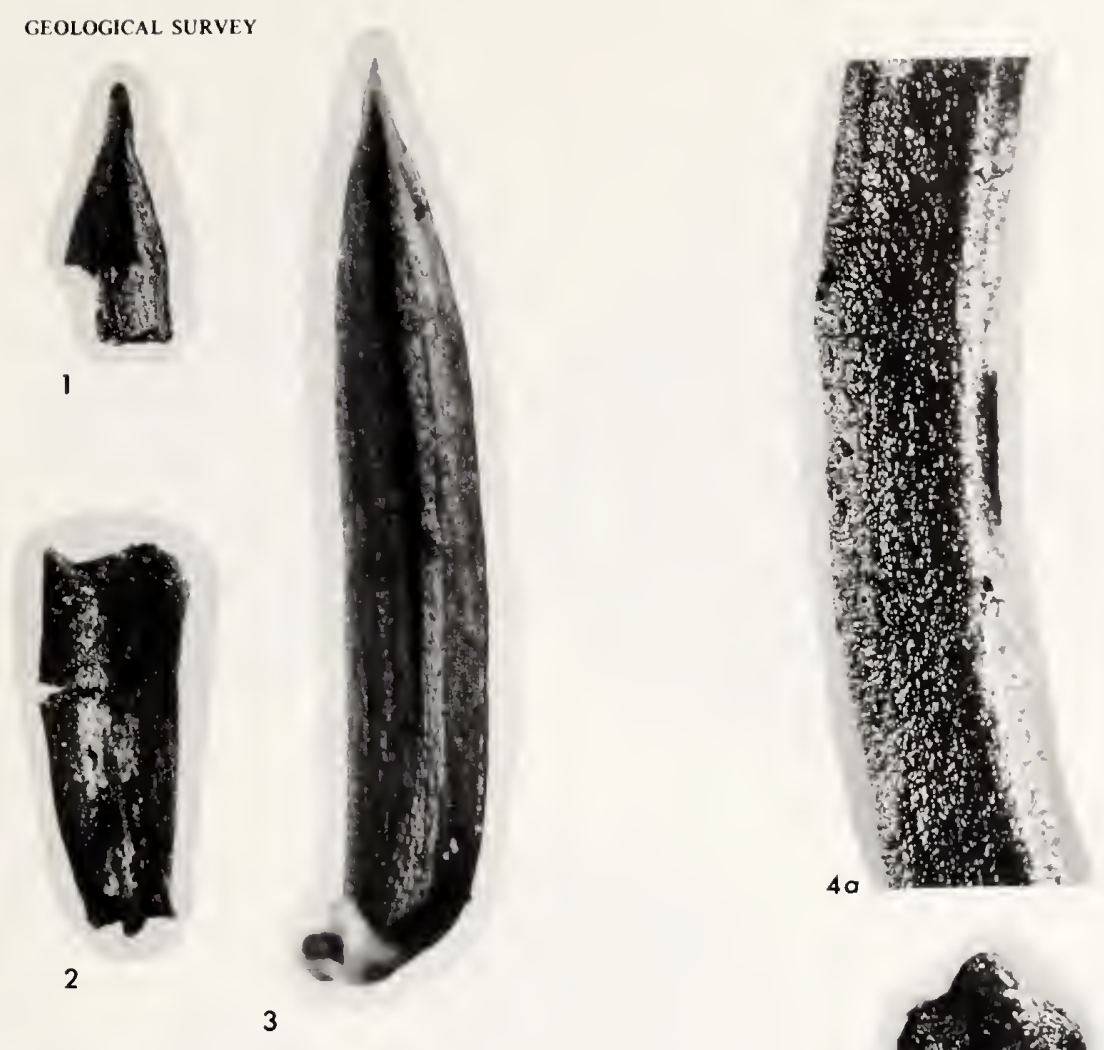

PROFESSIONAL PAPYR 729-\$ PLATE S
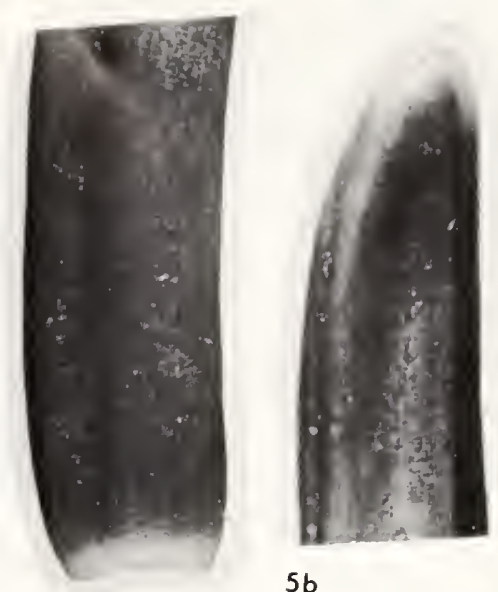

50

$5 b$
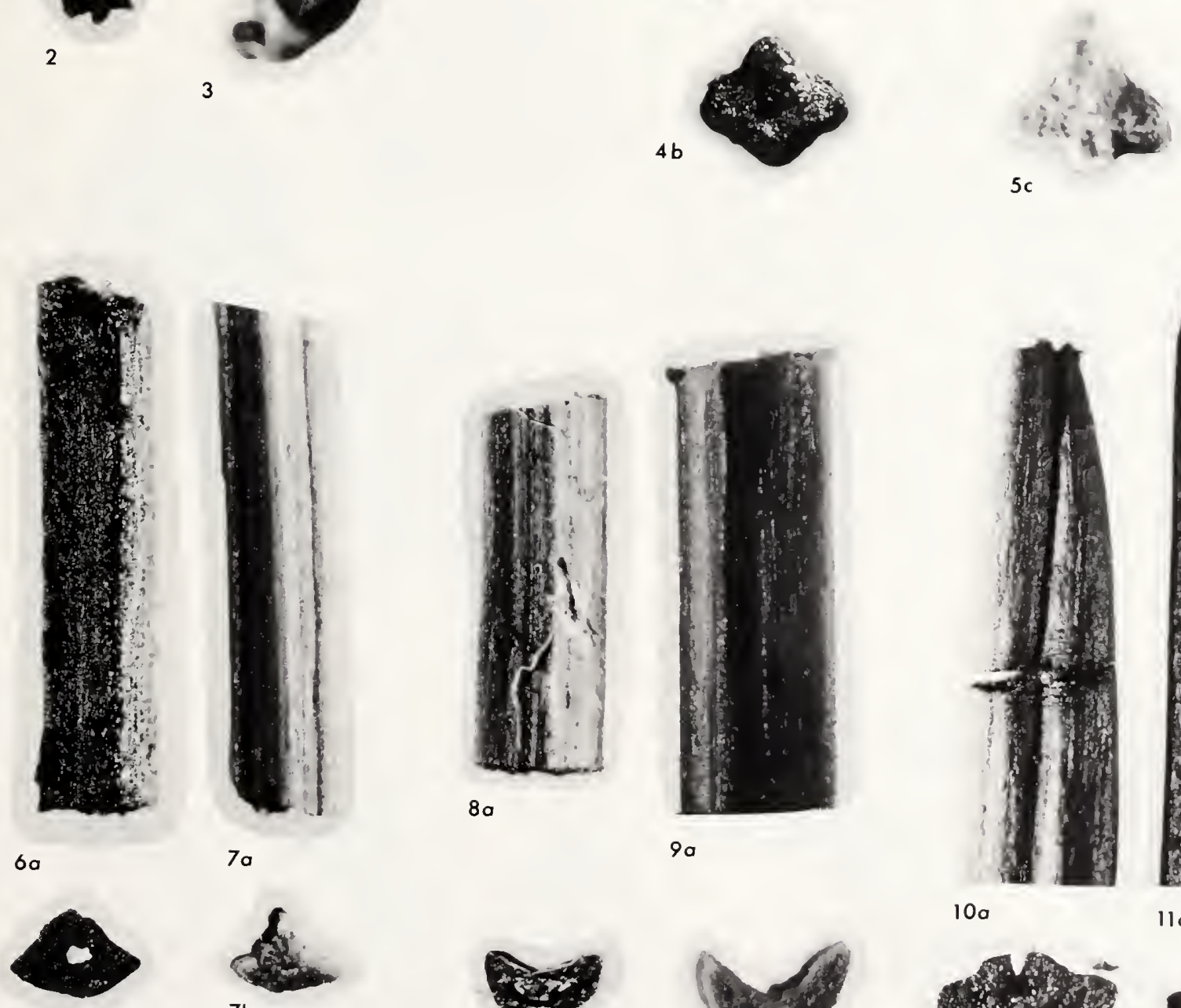

$7 a$

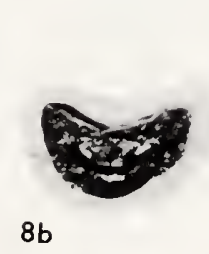

90
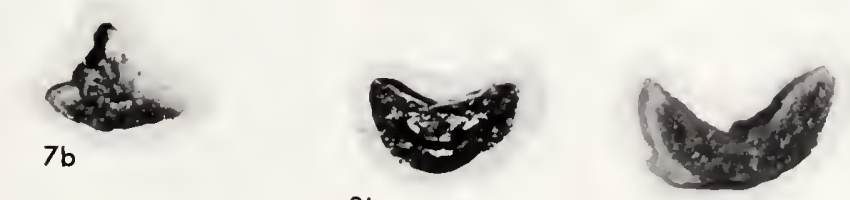

$9 b$

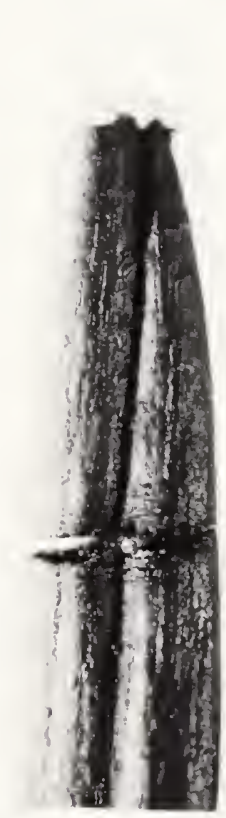

$10 a$

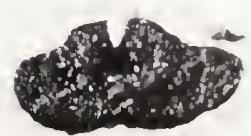

$10 \mathrm{~b}$

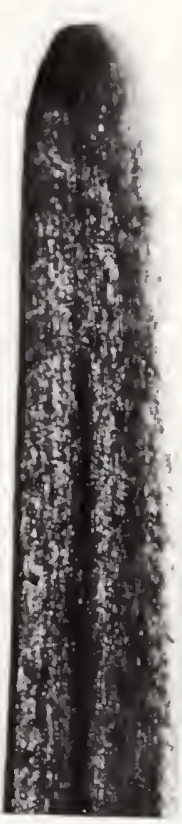

110

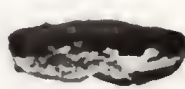

116 


\section{PLATE 6}

Fossil and modern fruits, scales, seeds, perianth, and bracts. $\times 11$.

Figure 1, 2. Alnus tenuifolia fruits.

1. Fossil fragment; Buckbean fen core, 400- to 405-cm depth.

2. Modern; COLO 2181.

3, 4. Betula glandulosa catkin scales.

3. Fossil; Lilypad pond core, 885 - to $890-\mathrm{cm}$ depth.

4. Modern; COLO 2250.

5, 6. Menyanthes trifoliata seeds.

5. Fossil; Buckbean fen core, 55- to 60-cm depth.

$6 a, 6 b$. Modern; RGB-197.

7, 8. Rumex fueginus perianth.

7. Fossil; Buckbean fen core, 445- to $450-\mathrm{cm}$ depth.

8. Modern; COLO 56854.

9 -11. Rumex salicifolius fruits.

9. Fossil; Lilypad pond core, 880 - to $885-\mathrm{cm}$ depth.

10, 11. Modern; COLO 181168.

12, 13. Populus balsamifera bracts.

12. Fossil fragments; Buckbean fen core, 805- to 810-cm depth.

13. Modern; COLO 107394. 

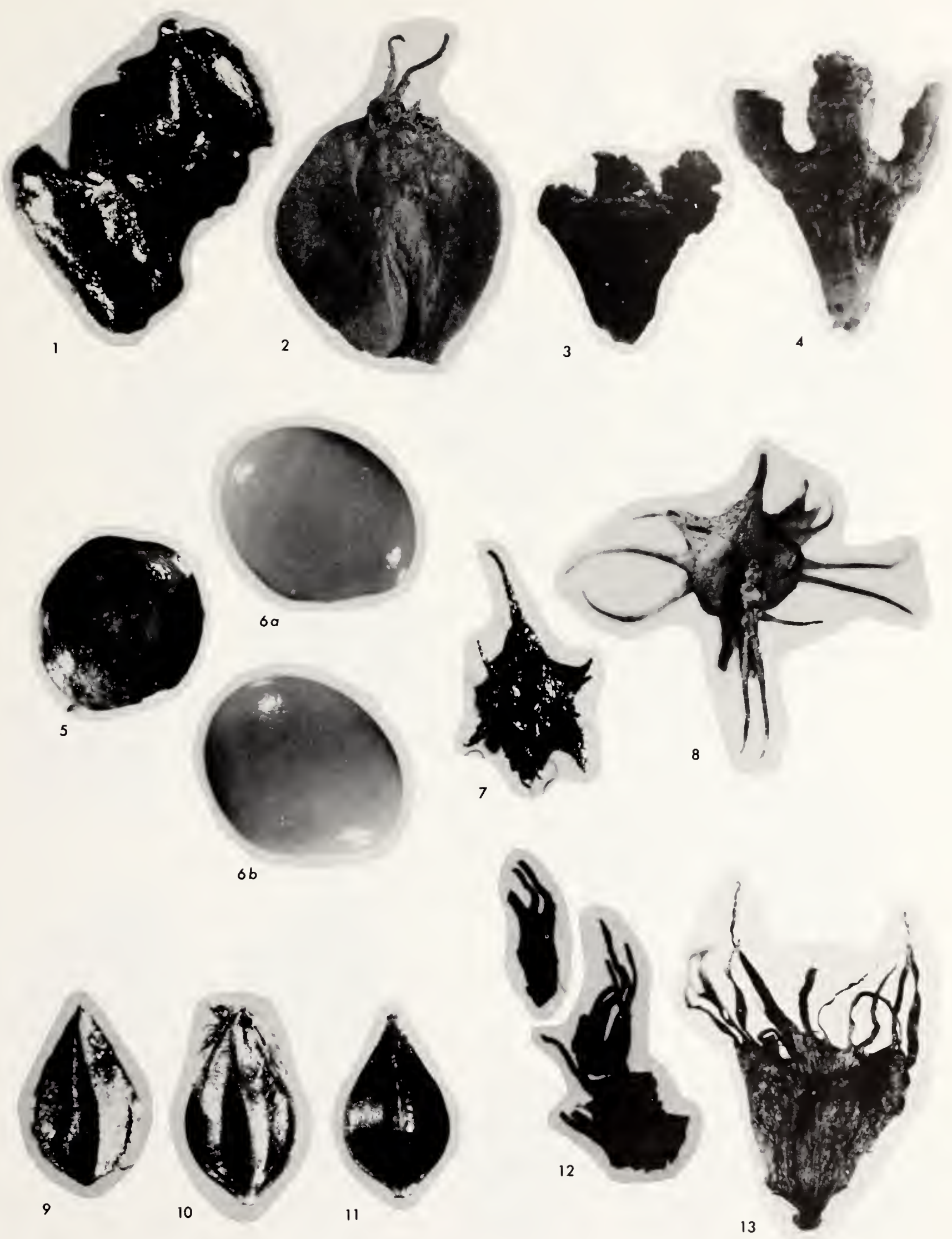


\section{PLATE 7}

Fossil and modern fruits, perigynia, and fruit-stones. $\times 11$.

F IGURE 1. Nuphar luteum ssp. polysepalum. Fossil fruit; Buckbean fen core, 360- to 365-cm depth.

2-4. Carex limosa fruits.

2. Fossil; Buckbean fen core, 0 - to 5-cm depth.

3, 4. Modern; RGB - 152 .

$5-7$. Carex vesicaria perigynia.

5. Fossil; Buckbean fen core, 0- to 5-cm depth.

6, 7. Modern; RGB -87 .

8-10. Carex ultriculata perigynia.

8. Fossil; Buckbean fen core, 5- to 10-cm depth.

9, 10. Modern; RGB - 277.

11, 12. Potamogeton alpinus fruit with covering.

11. Fossil; Buckbean fen core, 820 - to $825-\mathrm{cm}$ depth.

12. Modern; COLO 131646.

13, 14. Potamogeton filiformis fruit-stones.

13. Fossil; Lilypad pond core, 980 - to $985-\mathrm{cm}$ depth.

14. Modern; COLO 199776.

15-17. Potamogeton gamineus fruit-stones.

15. Fossil; Buckbean fen core, 450 - to $455-\mathrm{cm}$ depth.

16, 17. Modern; COLO 72388. 

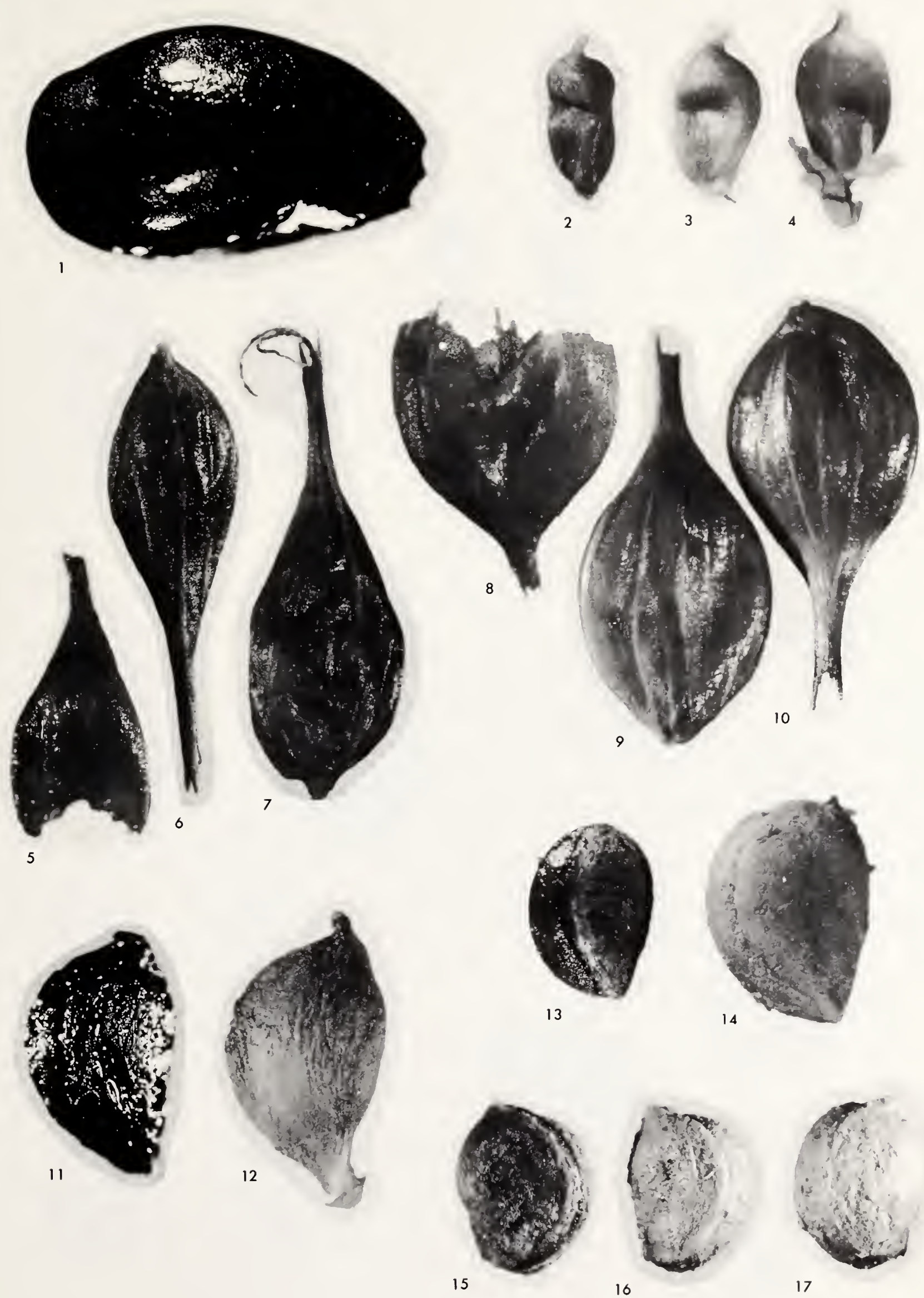

NUPHAR, CAREX, AND POTAMOGETON 


\section{PLATE 8}

Fossil and modern seeds and fruits. $\times 17$.

FIGURE 1-3. Descurainia californica seeds.

1a, 1b. Fossil; Lilypad pond core, 910- to 915-cm depth.

2, 3. Modern; COLO 13079.

4-7. Epilobium glandulosum-type seeds.

4. Fossil; Buckbean fen core, 145- to $150-\mathrm{cm}$ depth.

5-7. Modern-Epilobium adenocaulon (included within this morphological type); COLO 181161.

8-10. Epilobium lactiflorum seeds.

8. Fossil; Lilypad pond core, 805- to 810-cm depth.

9, 10. Modern; COLO 134413.

11, 12. Ranunculus aquatilis fruits.

11. Fossil; Lilypad pond core, 870- to 875-cm depth.

12. Modern; RGB - 151.

13-15. Potentilla biennis fruits.

13. Fossil; Lilypad pond core, $885-$ to $890-\mathrm{cm}$ depth.

14, 15. Modern; COLO 209920.

$16-19$. Potentilla gracilis type fruits.

16, 17. Fossil; Lilypad pond core, $955-$ to $960-\mathrm{cm}$ depth.

18, 19. Modern; RGB-124a.

$20-22$. Potentilla palustris fruits.

20. Fossil; Buckbean fen core, 5- to $10-\mathrm{cm}$ depth.

21, 22. Modern; RGB-148. 


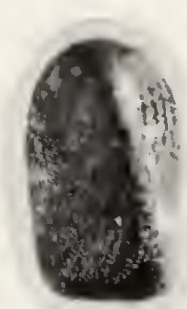

10

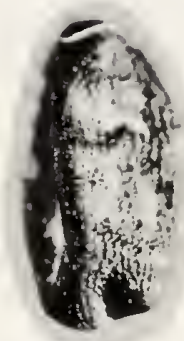

$1 b$

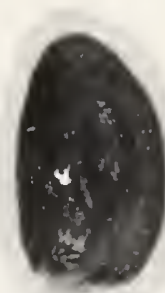

2

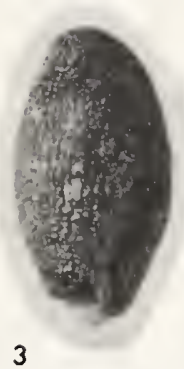

3

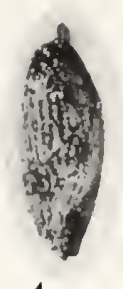

4
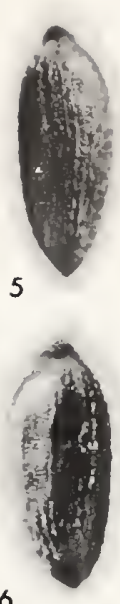

6
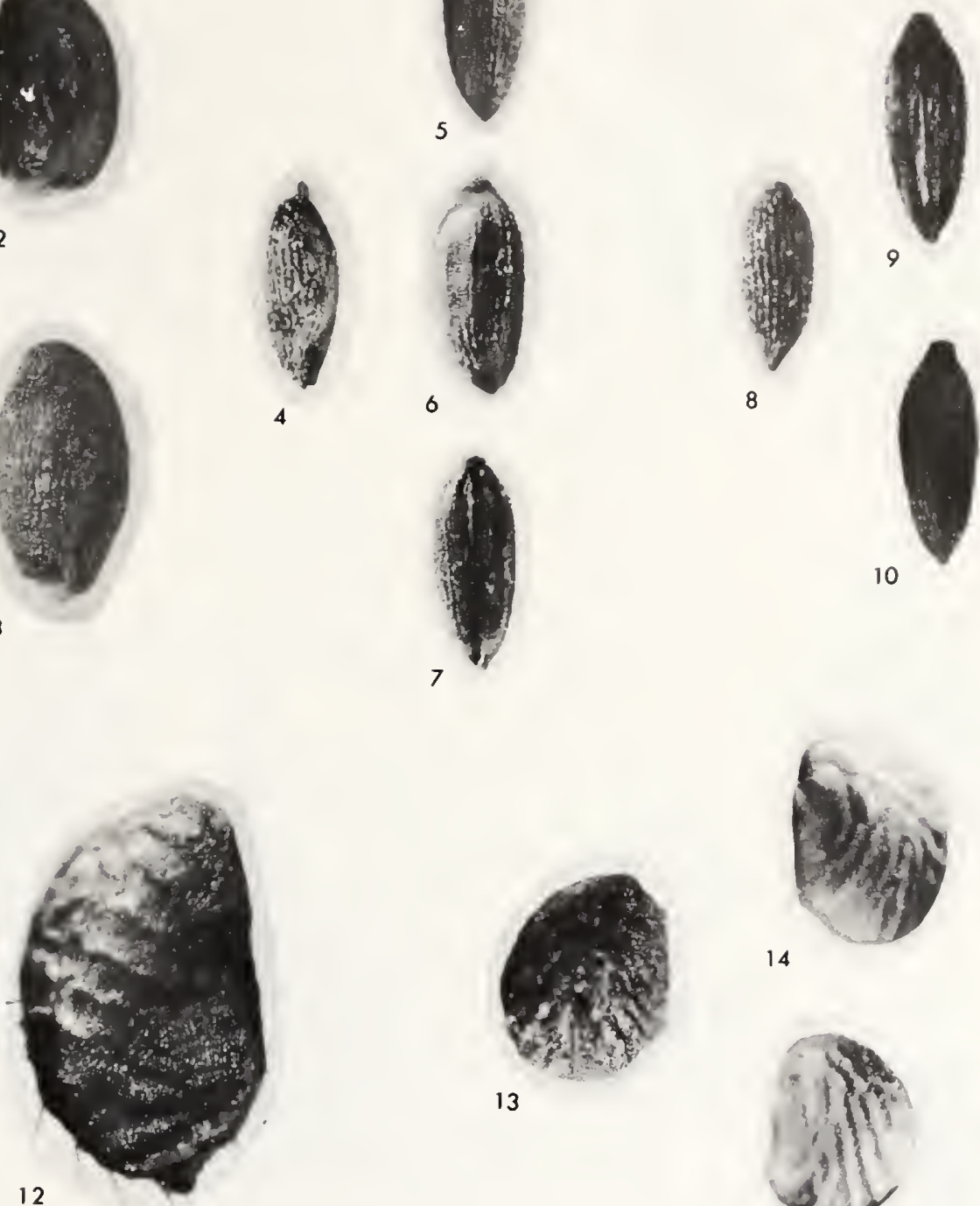

13

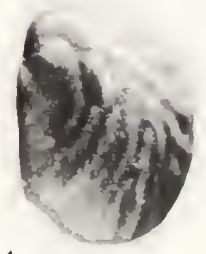

14

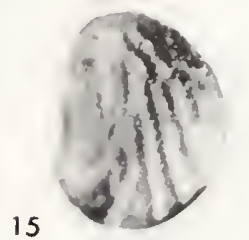

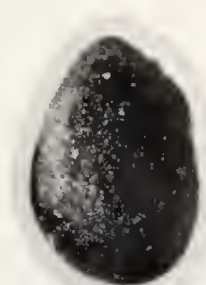

16

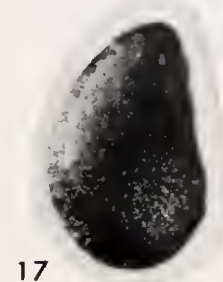

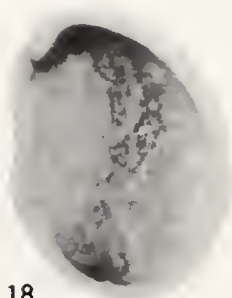

18

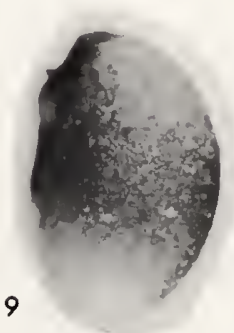

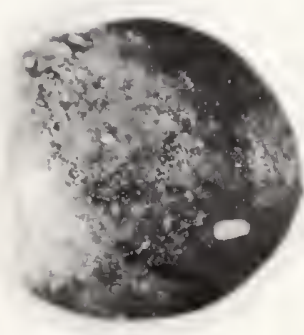

20

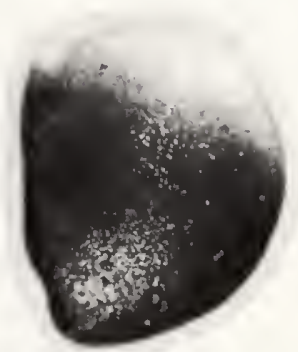

21

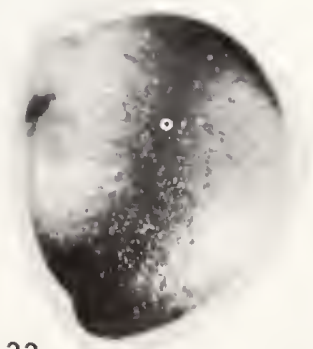

DESCURAINIA, EPILOBIUM, RANUNCULUS, AND POTENTILLA 


\section{PLATE 9}

Fossil perigynia, fruits, and seeds from Buckbean fen core and modern perigynia, fruits, and seeds. $\times 16$.

Figure 1, 2. Carex aquatilis perigynia and fruits.

1. Fossil; $165-$ to $170-\mathrm{cm}$ depth.

2. Modern; COLO 53127.

$3-5$. Carex canescens perigynia and fruits.

3. Fossil; 0- to 5 -cm depth.

4, 5. Modern; R. G. Baker collection.

6-8. Carex diandra perigynia and fruits.

6. Fossil; 0- to 5-cm depth.

7, 8. Modern; RGB-147.

9 - 11. Eleocharis macrostachya fruits.

9. Fossil, corroded; $475-$ to $480-\mathrm{cm}$ depth.

10, 11. Modern; COLO 95235.

12 - 14. Glyceria maxima ssp. grandis seeds.

12. Fossil; 435 - to $440-\mathrm{cm}$ depth.

13, 14. Modern; COLO 20242.

15, 16. Naias flexilis seeds.

15. Fossil; 475- to $480-\mathrm{cm}$ depth.

16. Modern; COLO 106552. 

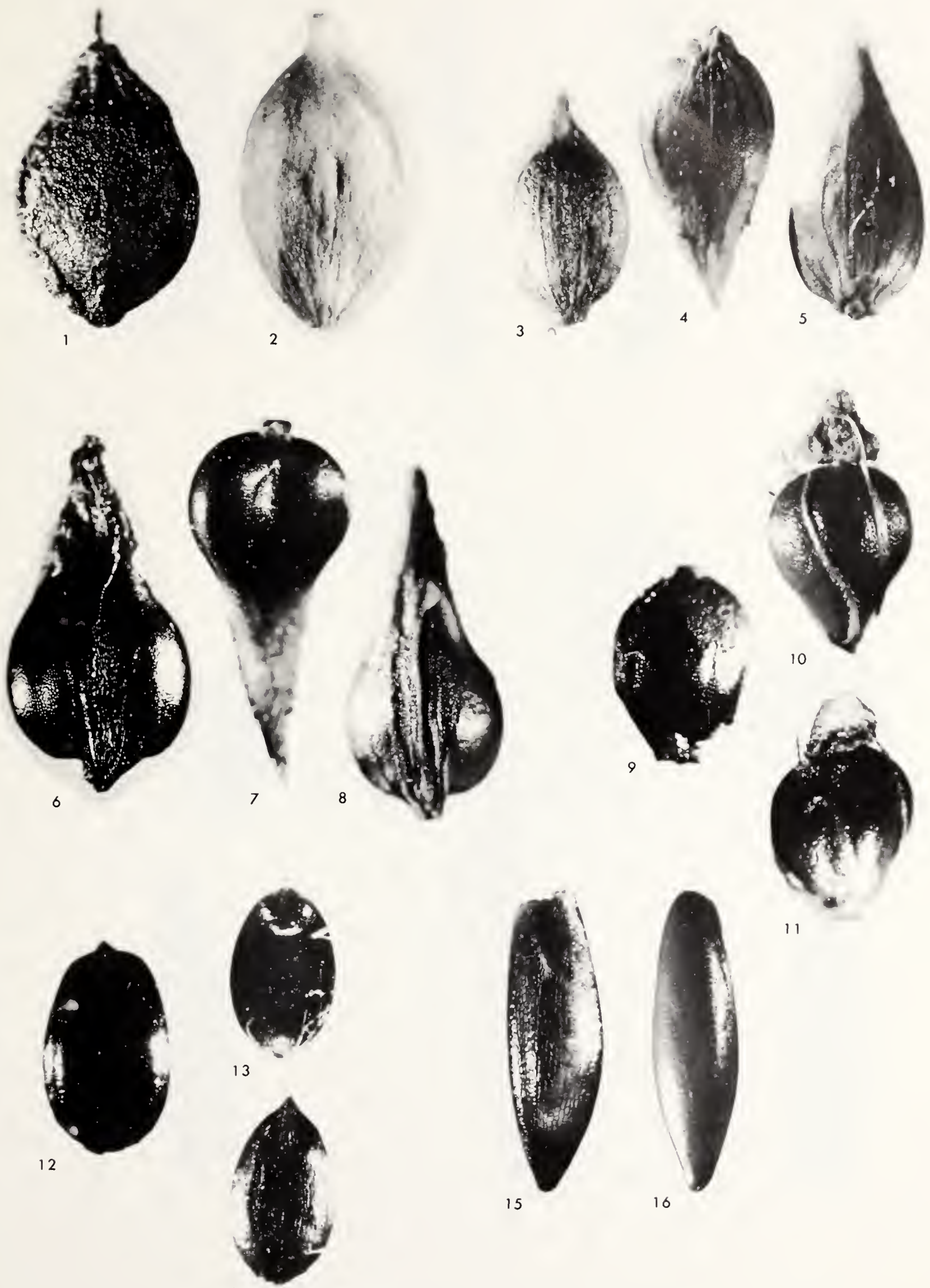

11 


\section{PLATE 10}

Fossil and modern fruits and seeds. $\times$ ca. 27

Figure 1. cf. Vaccinium. Fossil seed; Lilypad pond core, 990- to 995-cm depth. 2-6. Saxifraga rhomboidea seeds.

$2 a, 2 b$. Fossil; Lilypad pond core, 930 - to $935-\mathrm{cm}$ depth. 3-6. Modern; COLO 38885.

7-11. Saxifraga caespitosa seeds.

7. Fossil; Lilypad pond core; 930 - to $935-\mathrm{cm}$ depth. 8-11. Modern; COLO 180253.

12 - 14. Rorippa islandica-type seeds.

12. Fossil; Buckbean fen core, 410- to 415 -cm depth.

13, 14. Modern; COLO 197251.

15-17. Typha fruits.

15. Fossil; Buckbean fen core, 665- to $670-\mathrm{cm}$ depth.

16. Modern fruit with covering membrane; COLO 41239.

17. Modern fruit with membrane removed; COLO 41239. 


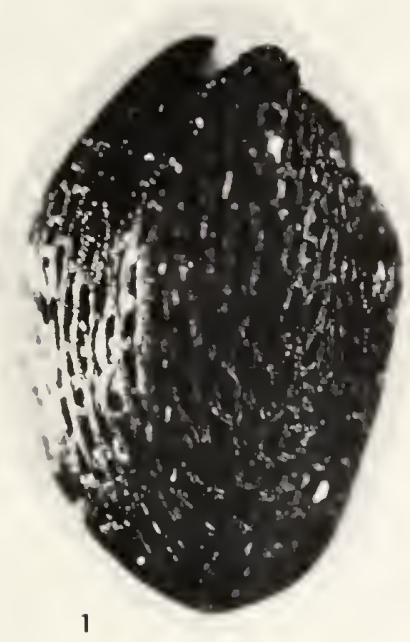

$2 a$

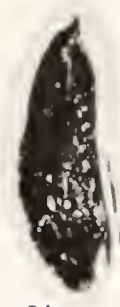

$2 b$

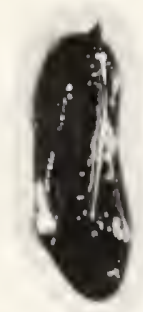

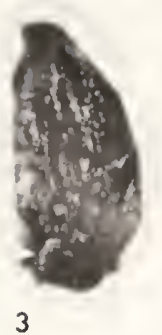
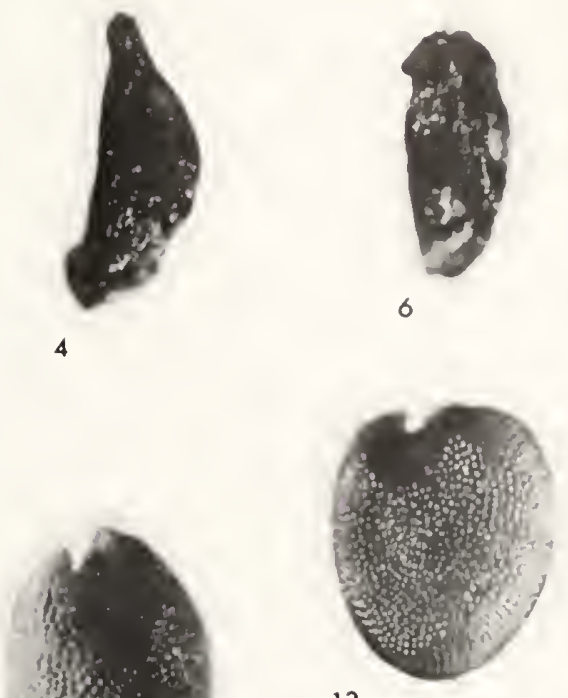

13

14

5

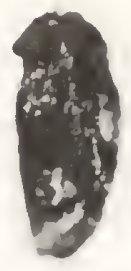

6

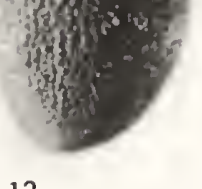

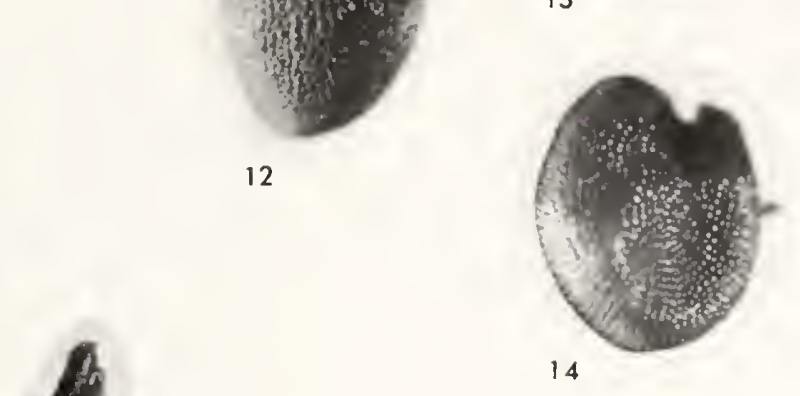

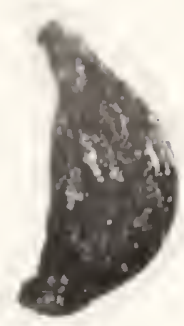

11
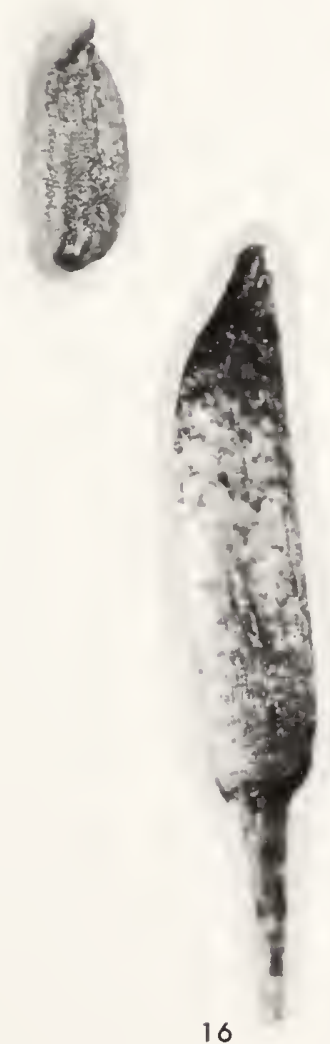

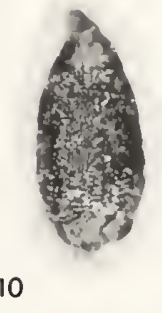

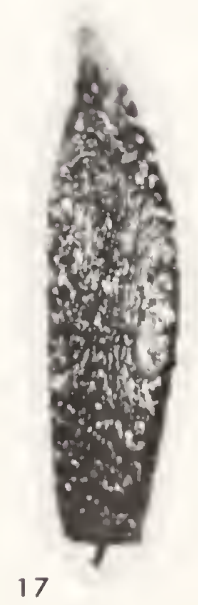

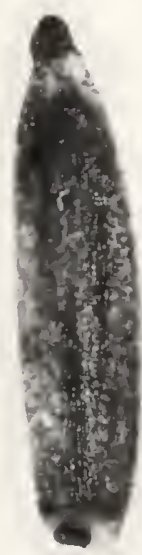

15

9

cf VACCINIUM, SAXIFRAGA, RORIPPA, AND TYPHA 


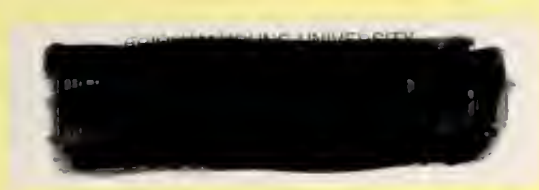




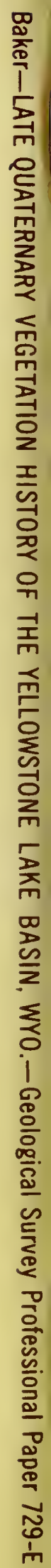

